\title{
Community Participation in Education \\ A Case Study in the Four Remote Primary Schools in Samlot District, Battambang Province, Cambodia
}

By:

\section{LOEURT TO}

ID: 300316046

\begin{abstract}
Supervisor: Dr Polly Stupples
School of Geography, Environment and Earth Sciences, Victoria University of Wellington
\end{abstract}

A thesis submitted to Victoria University of Wellington in partial fulfilment of requirements for the degree of Master of Development Studies

School of Geography, Environment and Earth Sciences

Victoria University of Wellington

March 2016 



\section{ABSTRACT}

This study was conducted to investigate the nature of community participation in education in a remote district in Cambodia. A case study approach was used to explore the issue and employed mixed research methods for data collection. Epstein's participation and Bray's degree of community participation were used as analytical frameworks. The study contributes to a wide body of literature in participation in education, but which is underresearched for rural Cambodia. The study focussed on the forms and processes of participation by parents, community members and education stakeholders in primary schools in remote areas.

The study discovered a range of social practices in community participation in education. The degrees of participation varied depending on the types of participation and the participants. Parents had direct participation in their children's learning at home, and indirect participation through resource contribution for school development. In addition, the community participated in education through their main representatives, the School Support Committees (SSCs). SSCs were found to possess power in the decision-making processes in school and education development.

The most common type of participation was collaborative resource contribution for school development. This practice reflected the traditional culture of participation of Cambodian society but there was also a sign of behavioural change to focus more on children's learning. Teachers and School Support Committees were the drivers in bringing community and parents to participate in education. They were the facilitators, communicators, network connectors and mobilizers for school and education development.

This case study suggests that a shift in focus (on the part of the government, nongovernmental organizations and education stakeholders) to support parental involvement in children's learning, rather than the traditional resource mobilisation, may better promote children's learning. Further research on parental involvement in children's learning could be conducted.

Key words: community, participation, community participation, community mobilization 


\section{ACKNOWLEDGEMENTS}

First of all, I would like to express my very sincere thanks to my parents, who gave me love and nurtured me, and who physically and mentally supported me to get an education from the first grade to the higher education. Without them, I would not have had the chance to have continuous success in life.

Next, I would like to express my gratitude to the New Zealand Agency for International Development (NZAID) Program, which has provided invaluable support for my study. I could not have managed to get post-graduate education from a well-known university without this support.

I would like to give my sincere thanks to my supervisor Dr. Polly Stupples, who has always given me support, direction and motivation toward the accomplishment of this Master's thesis. I regard her as my hero mentor.

I also would like give warm thanks to my wife who has accompanied me to New Zealand. She provides me with very warm care and support physically and mentally. It would be hard for me to achieve my degree without her company. On top of that, I cannot forget the motivation from my two children who always give me smiles. They are my motivation to pursue my post-graduate degree abroad.

Last but not least, I would like express my deep gratitude to my friends, classmates, student learning services support team, librarians, professors, and numerous university staff who have provided technical and academic support to me over the two academic years. I would like to revere them as my teachers and guides. 


\section{DEDICATION}

This thesis is dedicated to my parents; my beloved wife, Sophy ROEURM, my children, Molica SA LOEURT and Phyrayuth SA LOEURT, and to my brothers and sister. These people have given me care and love. 


\section{TABLE OF CONTENTS}

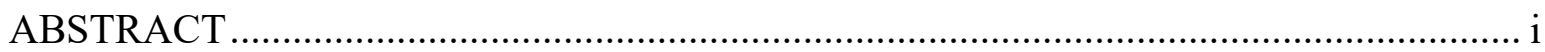

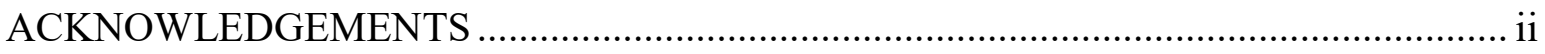

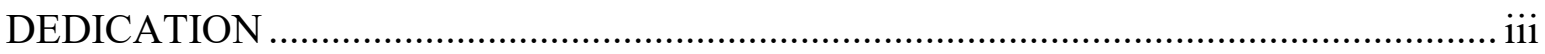

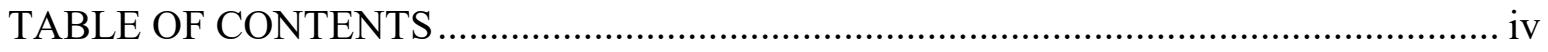

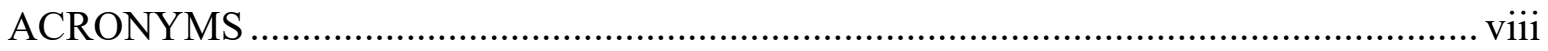

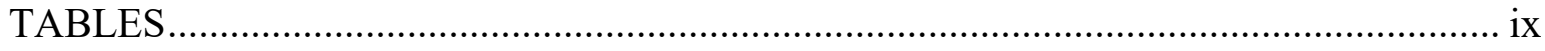

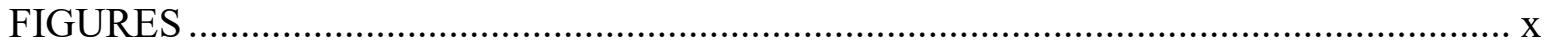

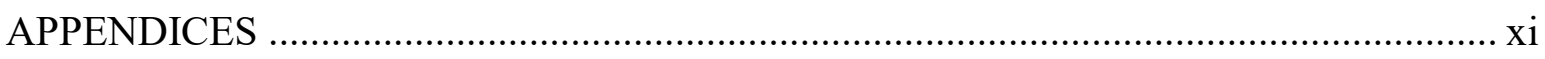

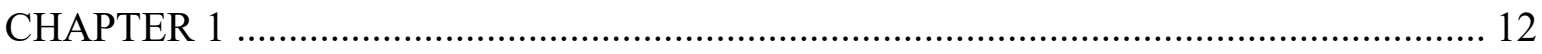

INTRODUCTION TO THE RESEARCH ............................................................. 12

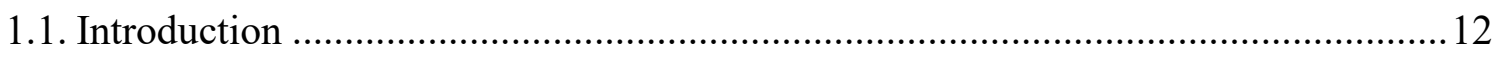

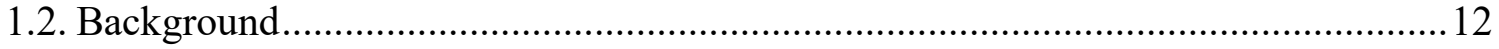

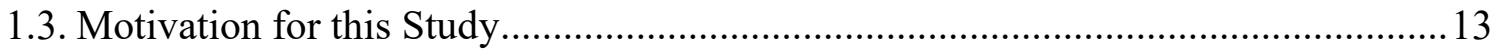

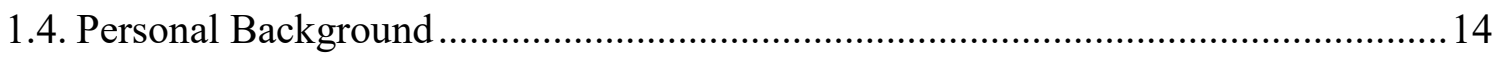

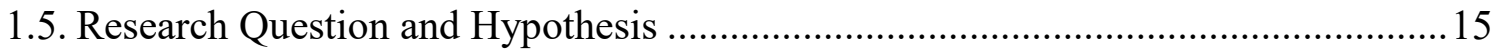

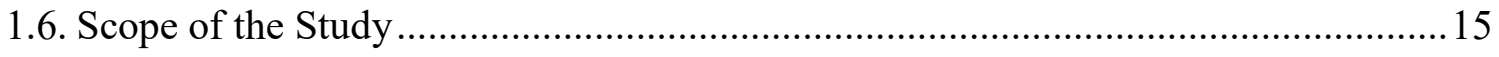

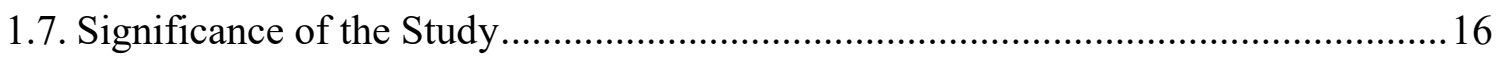

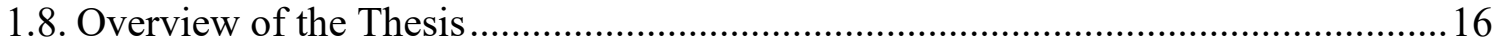

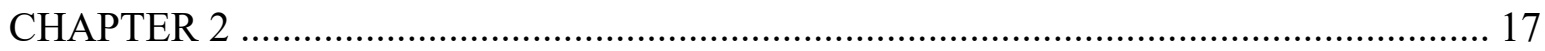

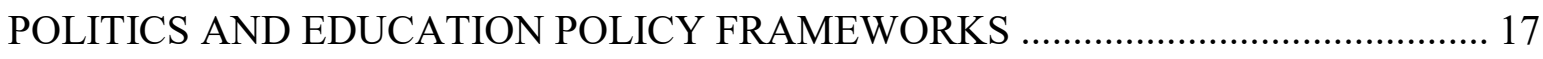

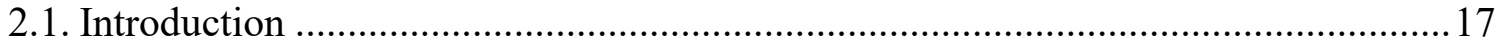

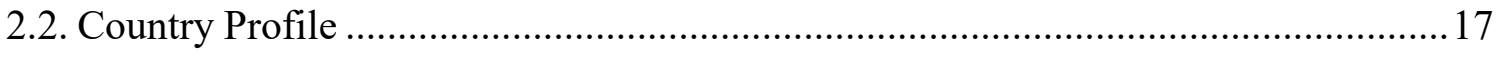

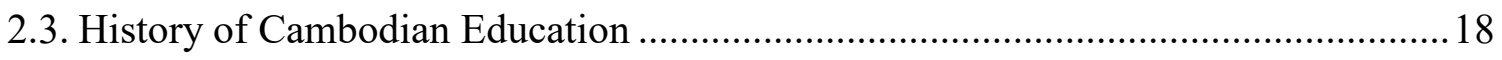

2.3.1. Education in the French Colonial Period .................................................... 18

2.3.2. Education in the Post-colonial Period ....................................................... 20

2.3.3. Education in the Khmer Rouge Regime.....................................................2 21

2.3.4. Education after the Khmer Rouge Regime ................................................. 22

2.3.5. Education Development in the Present ...................................................... 23

2.4. Cambodian Development Objectives ............................................................. 24

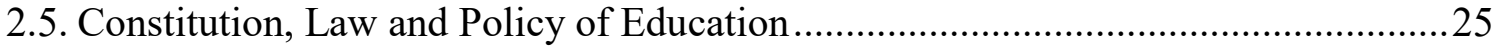




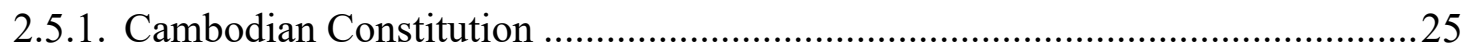

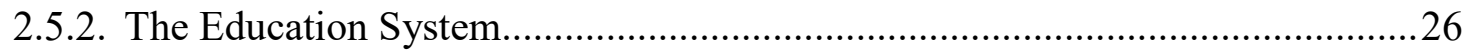

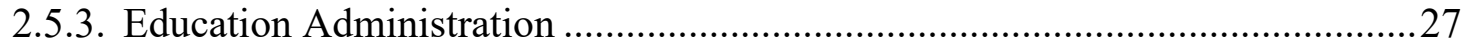

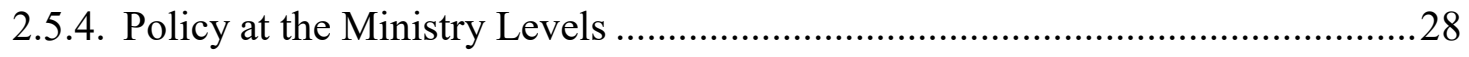

2.5.5. The Encouraging Policy for Participation and Partnerships ............................28

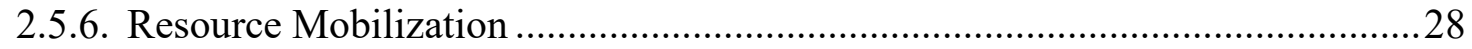

2.5.7. School Clustering Model and Decentralization in Education ..............................30

2.5.8. Child Friendly School Policy ………………….................................................... 31

2.5.9. School Support Committee (SSC) ……………............................................. 32

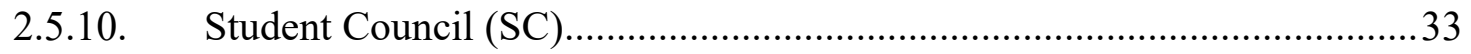

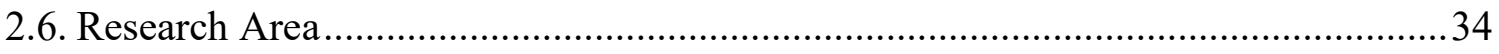

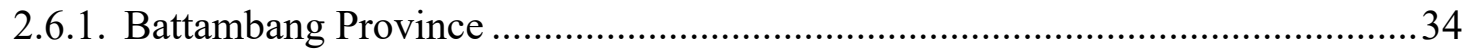

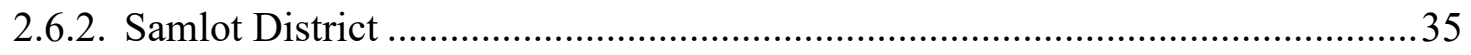

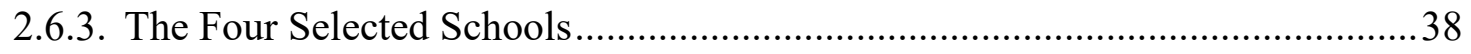

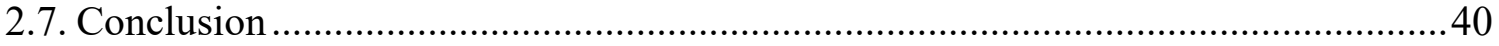

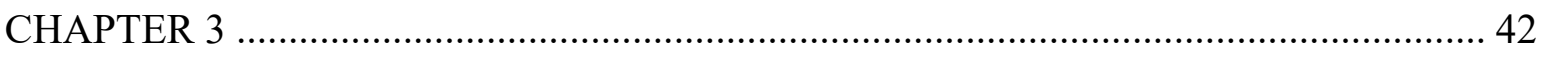

LITERATURE REVIEW ON COMMUNITY PARTICIPATION IN EDUCATION ....... 42

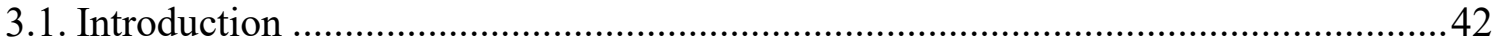

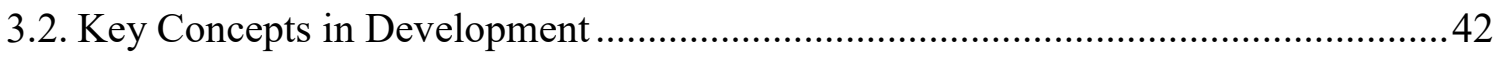

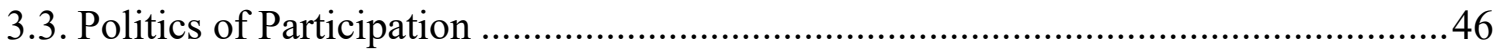

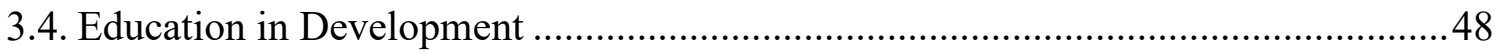

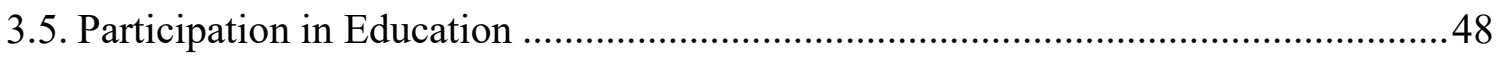

3.5.1. Forms of Participation: Epstein's Framework .................................................49

3.5.2. Levels of Community Participation in Education: Bray's framework................54

3.6. Mobilization of Community Resources..................................................................56

3.7. Recent Research in Community Participation in Education ....................................56

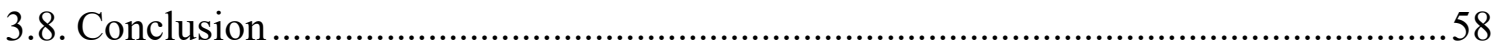

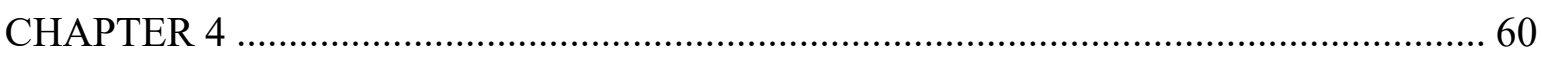

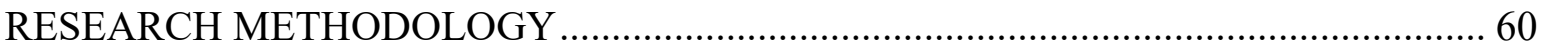

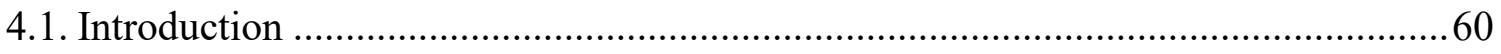

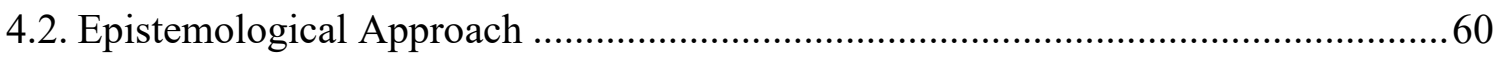

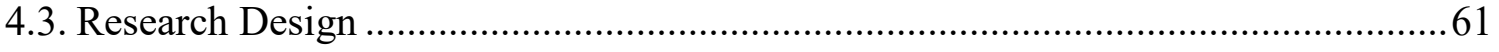


4.3.1. Research Objectives

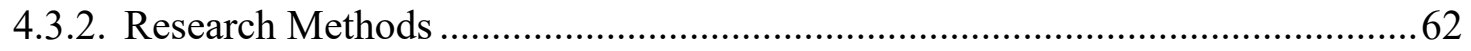

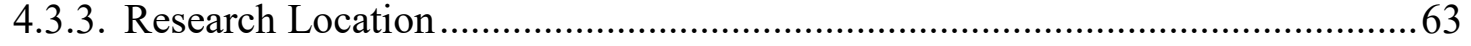

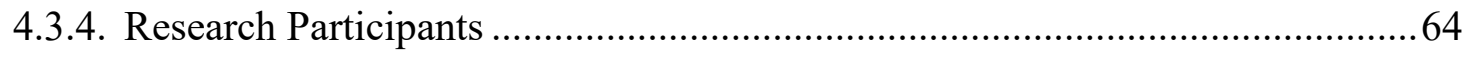

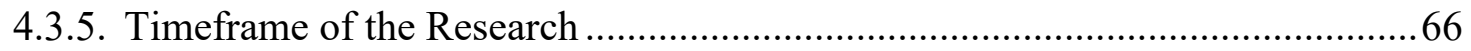

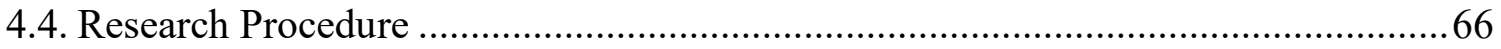

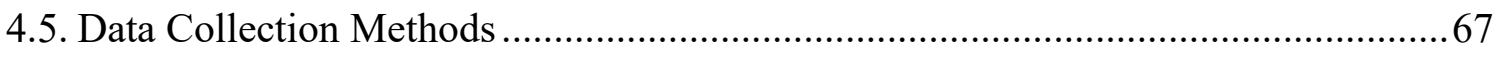

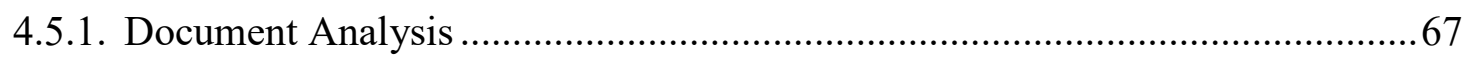

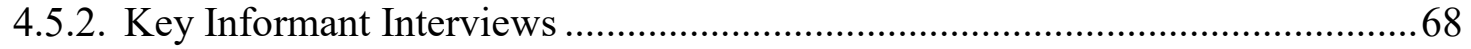

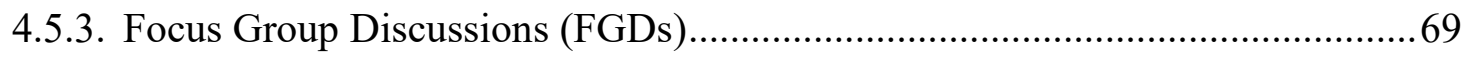

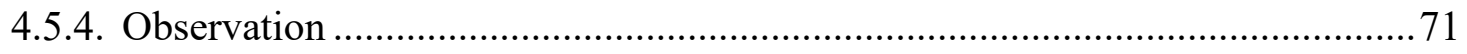

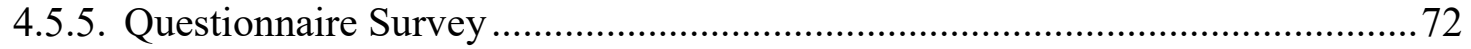

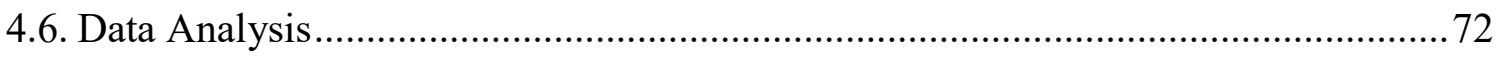

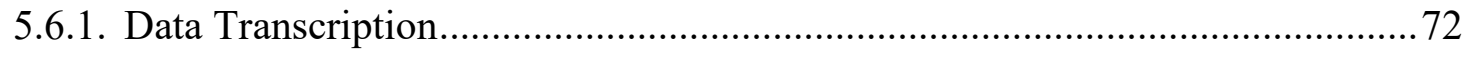

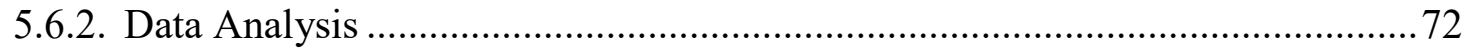

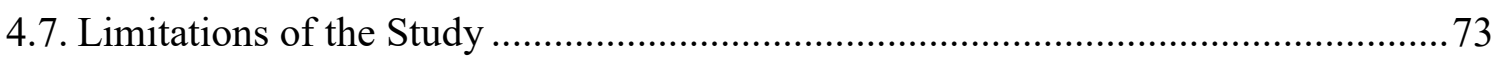

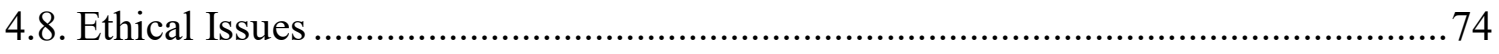

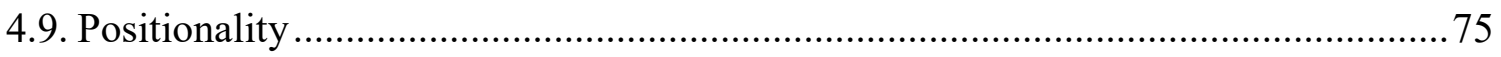

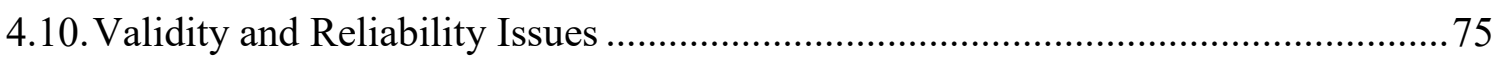

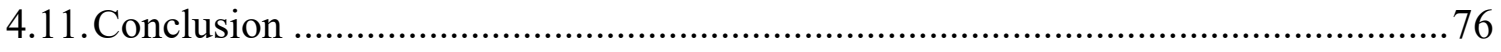

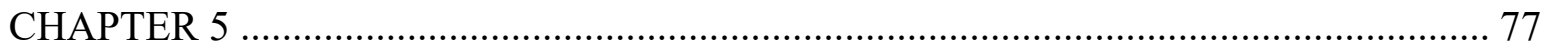

COMMUNITY PARTICIPATION IN EDUCATION IN REMOTE PRIMARY SCHOOLS

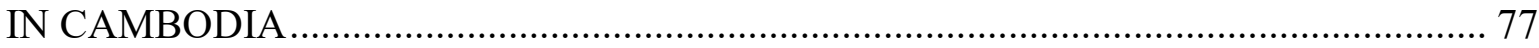

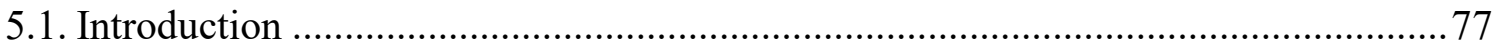

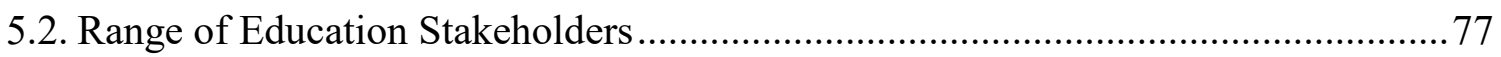

5.3. Perceptions about Community Participation in Education .................................... 78

5.4. Types and Processes of Community Participation in Education ............................. 80

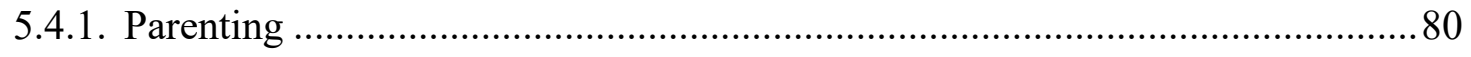

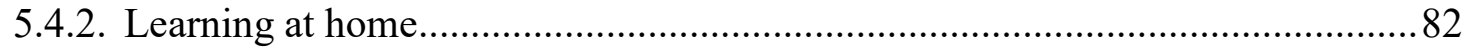

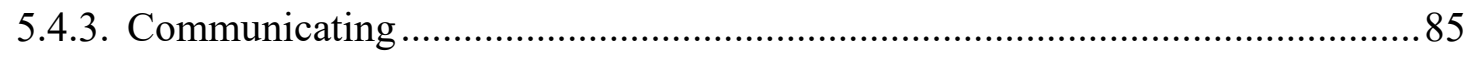

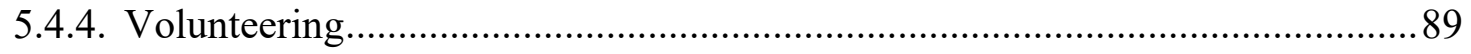

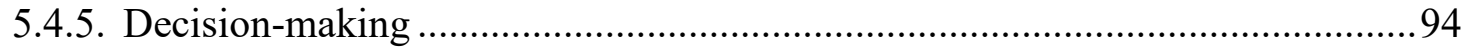




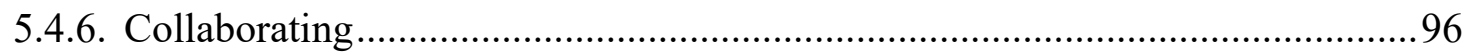

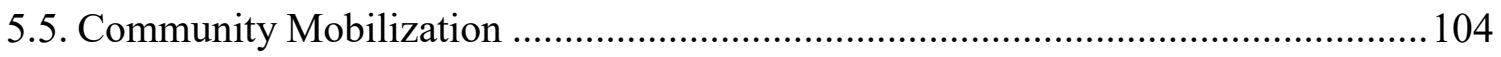

5.5.1. Local Resource Mobilization for School Development...................................104

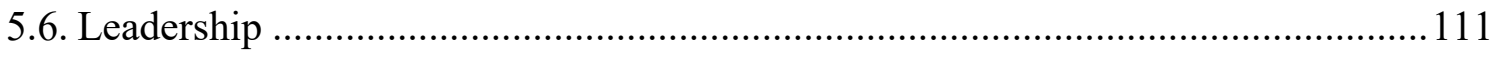

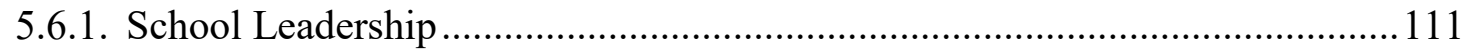

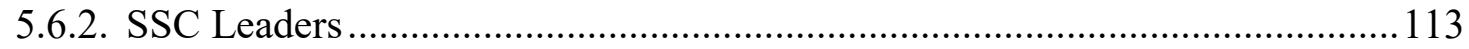

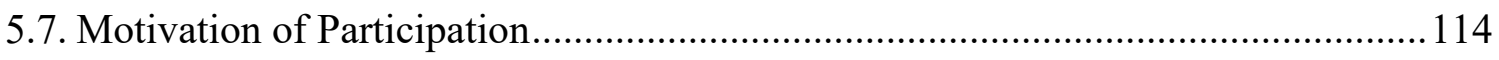

5.8. Obstacles to Participation ...............................................................................115

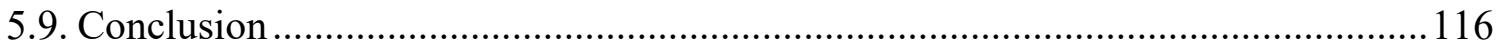

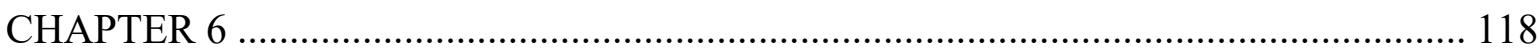

DEGREES OF COMMUNITY PARTICIPATION IN EDUCTION ................................ 118

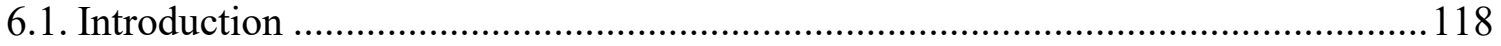

6.2. Degrees of Community Participation ................................................................ 118

6.3. Community Participation Policy and Practices …………...................................... 124

6.4. Traditional Practices of Community Participation ....................................................126

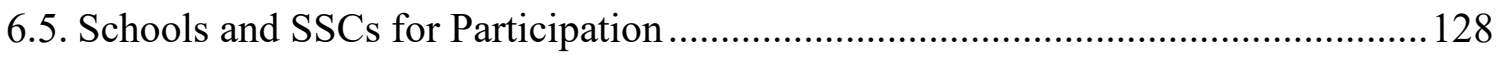

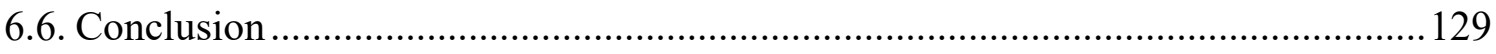

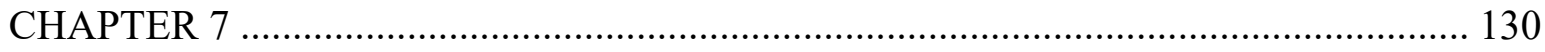

CONCLUSION AND RECOMMENDATION ……………........................................ 130

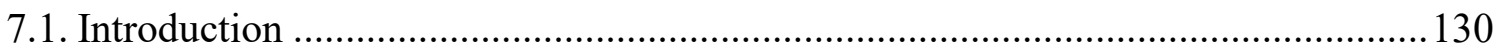

7.2. Key Findings - Practices of Community Participation in Education........................130

7.3. Community Resource Mobilization....................................................................... 132

7.4. Degrees of Community Participation in Education .................................................132

7.5. Recommendation for Better Participation in Education..........................................133

7.5.1. Parental Involvement in Children's Learning ...................................................133

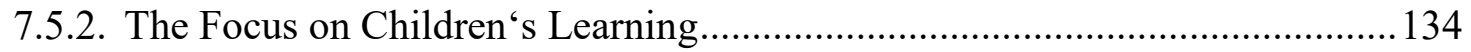

7.6. Limitations of the Study and Recommendations for Further Research....................135

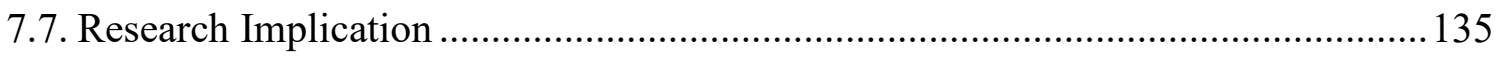

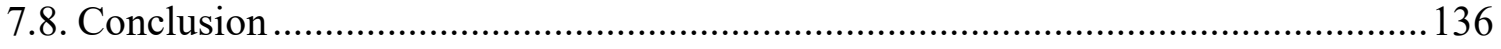

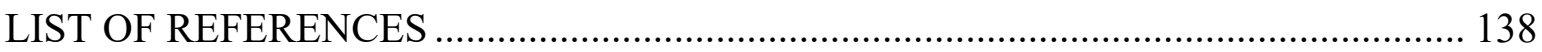

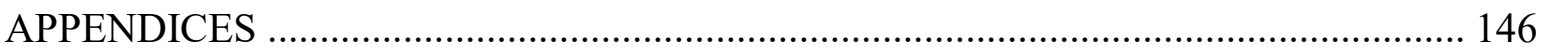




\section{ACRONYMS}

$\begin{array}{ll}\text { ADB } & \text { Asian Development Bank } \\ \text { CC } & \text { Commune Council } \\ \text { CFS } & \text { Child Friendly School } \\ \text { DoE } & \text { District office of Education } \\ \text { FGD } & \text { Focus Group Discussion } \\ \text { KHEN } & \text { Khmer Education Networks } \\ \text { KII } & \text { Key Informant Interview } \\ \text { MJP } & \text { Maddox Jolie Pitt (Cambodian Community Development Organization) } \\ \text { MoEYS } & \text { Ministry of Education, Youth and Sport } \\ \text { MoI } & \text { Ministry of Interior } \\ \text { MoP } & \text { Ministry of Planning } \\ \text { RGC } & \text { Royal Government of Cambodia } \\ \text { SC } & \text { Student Council } \\ \text { SCC } & \text { Save the Children Cambodia } \\ \text { SSC } & \text { School Support Committee } \\ \text { UN } & \text { United Nations } \\ \text { UNESCO } & \text { United Nations Educational, Scientific and Cultural Organization } \\ \text { UNICEF } & \text { United Nations Children's Emergency Fund } \\ \text { VUWHEC } & \text { Victoria University of Wellington Human Ethics Committee } \\ \text { WB } & \text { The World Bank } \\ \text { WVC } & \text { World Vision Cambodia } \\ \end{array}$




\section{TABLES}

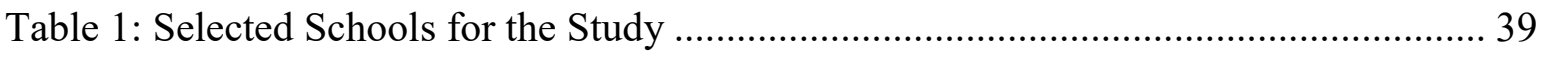

Table 2: Epstein's Framework for Forms of Participation ........................................... 50

Table 3: Degrees of Community Participation in Education ......................................... 54

Table 4: New Matrix Forms and Degrees of Participation in Education .......................... 55

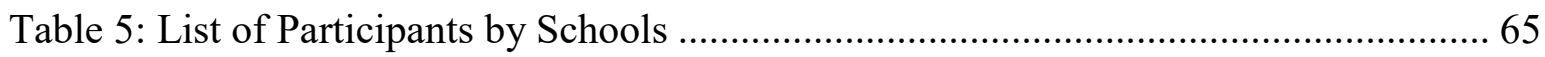

Table 6: List of Participants by Community/Institutions ............................................ 65

Table 7: Data Collection Tools .................................................................................. 70

Table 8: Perspectives of Participants on Community Participation in Education .............. 79

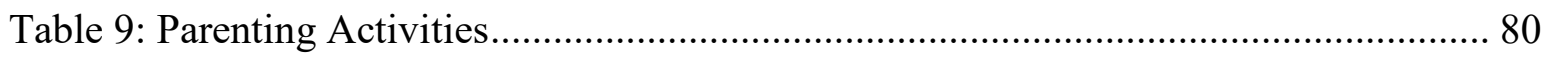

Table 10: Parental Activities at Home ....................................................................... 83

Table 11: Obstacles of Participation in Education.................................................... 84

Table 12: Communication Tools in School-to-community …...................................... 86

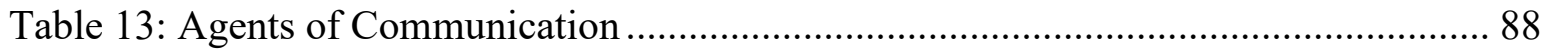

Table 14: Mixed Components of School Support Committee ....................................... 90

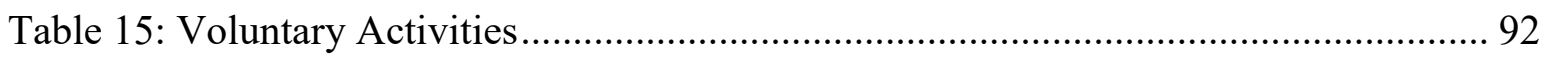

Table 16: Community Collaboration for Education.................................................... 97

Table 17: Type of Community Contribution in the School Development........................ 99

Table 18: Financial Contribution for School Development (2015) ............................. 100

Table 19: Micro Projects in the Four Selected Schools ........................................... 105

Table 20: Motivation Factors of Participation in Education ......................................... 114

Table 21: Obstacles of Participation in Education.................................................. 115

Table 22: Types and Degrees of Community Participation in Education in the four Primary

Schools in Samlot District...................................................................................... 119 


\section{FIGURES}

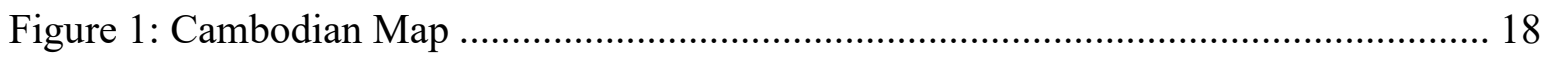

Figure 2: Hierarchy of Education Administration …………………................................. 27

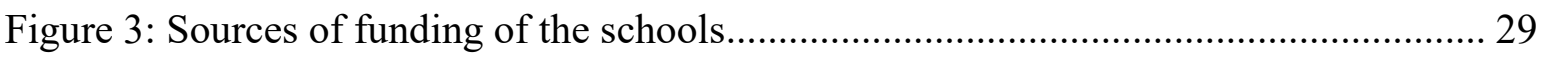

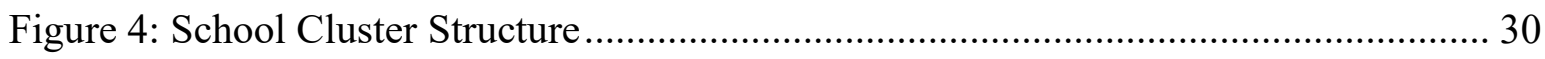

Figure 5: School Support Committee Structure ……………………………………….... 33

Figure 6: Student Council Structure.............................................................................. 34

Figure 7: Map of Battambang Province ………………………………………………..... 35

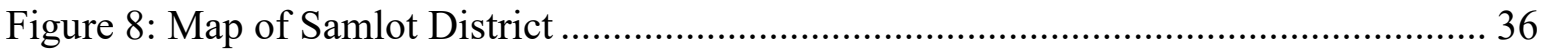

Figure 9: Comparison of education statistic ................................................................... 38

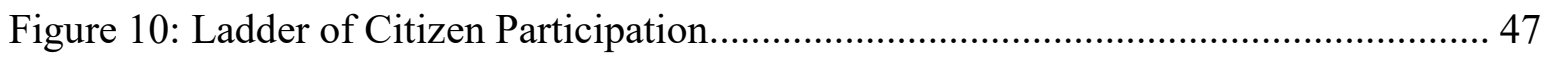

Figure 11: Range of identified Educational Stakeholders................................................ 78

Figure 12: Structure of School Support Committee............................................................ 90

Figure 13: Structure of Student Council ........................................................................ 91

Figure 14: Children's Volunteering Activity ……………............................................... 93

Figure 15: Children Coordinate the Traffic after Class ..................................................... 93

Figures 16: Constructions with Communities' Resource Contribution ............................... 101

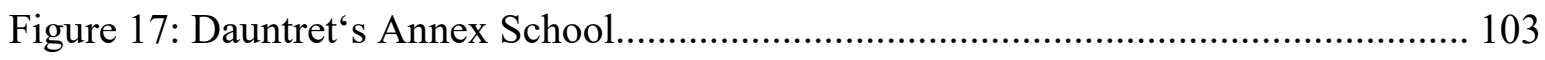

Figure 18: The First Model of Community Mobilization (M1)......................................... 107

Figure 19: The Second Model of Community Mobilization (M2) …………………........ 109

Figure 20: Degrees of Participation in Education in Four Schools of Samlot District...... 124 


\section{APPENDICES}

Appendix 1: Guiding Questions for Interviews ................................................. 146

Appendix 2: List of Questionnaire for Survey ........................................................ 148

Appendix 3: Observation Checklist ...................................................................... 150

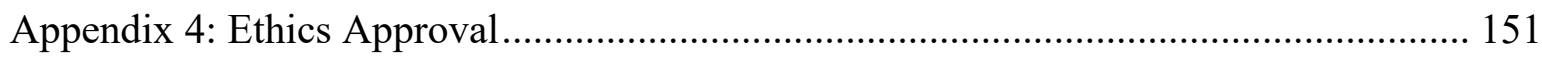

Appendix 5: Letter from Research Supervisor...................................................... 152

Appendix 6: Information Sheet for Interviews .................................................... 153

Appendix 7: Consent Form for Interviews ........................................................... 155

Appendix 8: Information Sheet for FGDs...................................................... 156

Appendix 9: Consent Form for FGDs ............................................................... 158

Appendix 10: Permission Letter from DoE to Conduct a Study with Teachers ............... 159

Appendix 11: Permission Letter from Tasanh Commune............................................. 160

Appendix 12: Permission Letter from Sung Commune ........................................... 161

Appendix 13: Fund Raising Letter for School Renovation....................................... 162

Appendix 14: Invoice of Money Contribution.......................................................... 163 


\section{CHAPTER 1}

\section{INTRODUCTION TO THE RESEARCH}

\subsection{Introduction}

Community participation is crucial for the success of community development programs. Development projects and programs with strong participation can enhance ownership and sustainability in development (Kumar, 2000) and the projects are more likely to succeed in developing the community. Likewise, the participation of communities in education can enhance education and children's learning. Research has shown that the participation of families and communities in education has positive impacts on children's learning and can also increase children's learning potential which results in long-term impacts on children's lifelong learning (Epstein, 1992, 1995, 2006).

Existing research has found different forms and levels of community participation particularly in education (Epstein, 1995; Ngoun, 2012; Sanders, 2001; Griffin \& Steen, 2010; Pak, 2012). This study examined community participation in education in remote schools in Cambodia. It investigated the occurring forms and processes of community participation in education and community mobilization in a selection of schools. The degree to which the communities participate in education and the various modes of participation will be discussed through the analysis of the findings. This research is expected to add to the existing knowledge on community participation in education. It is also hoped that this research can improve education and children's learning in Cambodia through advocating for community participation in education.

\subsection{Background}

In Cambodia, the Ministry of Education, Youth and Sport (MoEYS) initiated a community participation policy - the School Support Committee (SSC) policy - for the formal education system in 1993 (MoEYS, 2012). The government decentralized the power of decision making to educational authorities at sub-national levels and all educational departments and schools have to comply with this policy. This policy regards the 
participation of the community as a central axis of education development. The resulting School Support Committees are similar to the parent-teacher association (PTA) or, in New Zealand, the Board of Trustees (as in Ministry of Education, 2015) and usually consist of representatives of parents and community members in schools. These committees share decision-making with school administrators in the planning, implementation, monitoring and evaluation of the school program.

\subsection{Motivation for this Study}

There are many different forms of community participation in education. Local people may participate through finance, the contribution of materials, labor and ideas. The processes through which different forms of participation occur are uneven and dependent upon the leadership, understanding and commitment of both the individuals and school administrators (Griffin \& Steen, 2010). Due to this variation, research into community participation in education in specific areas is needed, particularly in the remote schools in Cambodia. It is worthwhile to identify the characteristics of community participation because this can provide lessons that will contribute to the body of knowledge in the literature, as well as to more effective practice.

There have been an increasing number of studies into community participation in education. Community participation, or partnership frameworks and models, have been developed by scholars and researchers for educational institutions to enhance the collaboration between community people and parents in education (Epstein, 2006; Bray, 1999, 2001, 2003). However, studies are plentiful in the high income and middle income countries in Europe and in Asia such as in Japan, Hong Kong, Singapore and Korea but are far fewer in relation to less developed countries including Cambodia (Bray, 2003; Pang, 2004).

Of the research that exists on education in Cambodia, very few studies have investigated parental or community participation ${ }^{1}$ (Save the Children Cambodia, 2015). According to Save the Children Cambodia, only a few studies have been conducted in community

\footnotetext{
${ }^{1}$ According to Save the Children Cambodia (2015), the studies on community participation in education include Nguon (2011), Save the Children Cambodia (2013), UNDP (2013), Save the Children Cambodia (2014) and Save the Children Cambodia (2015).
} 
participation in education. In addition, even though the Cambodian government and some international development agencies (such as the World Bank, UNICEF, UNESCO and $\mathrm{ADB})$ have conducted research for their monitoring and progress reports on education, none of these documents focus on the involvement of community and families in education. The MoEYS has, however, shown support and encouragement for the engagement of communities and local partners in education development (MoEYS, 2014a, 2014b).

This study on community participation in education in Cambodia therefore addresses a significant gap in the literature and it is hoped that the research will be of value to educators, educational administrators, policy makers and community members concerned about education, especially in the South East Asia region. Key purposes of this study are to contribute to the literature on education frameworks in the development context through a focus on community participation in education, which remains under-researched, and to promote education through advocating for community participation.

\subsection{Personal Background}

My educational and personal background has influenced my decision to undertake this research. I am from Cambodia, which has a low Human Development Index (HDI) rating of 0.584 in 2013 (WB, 2015). The quality of education that I experienced in primary school was poor in terms of enrolment numbers, completion and learning achievement. Furthermore, the involvement of the local people in the education process was limited. Fortunately, I had the chance to train as a teacher which has shaped my career.

I have worked in education for nearly ten years. I started my first job as a primary school teacher in a state school in a remote community in Cambodia. A year later, I moved to work in the District Office of Education (DoE) in my hometown. These first two years of employment in different educational contexts enabled me to understand the situation of education at the local level. In the last seven years, I have worked as a development worker in the education sector for two NGOs (holding three different positions) in three different locations within Cambodia. This work experience has shaped my understanding about the education system of the country and inspired me to conduct this research into the involvement of the community in education, a factor that may contribute significantly to enhance children's learning. 


\subsection{Research Question and Hypothesis}

Based on my work experience in education in Cambodia and based on the theoretical models on community participation in education mentioned above, I hypothesized that community participation in education exists within Cambodia but that its strengths and weaknesses will vary in different contexts and there is little formal evaluation of these processes.

This research therefore explores this phenomenon with an overarching research question: How has community participation in education occurred in the remote primary schools of the Samlot district in Cambodia?

This is then broken down into four sub questions:

a. What forms of participation are taking place?

b. How has each form of participation occurred?

c. How have different schools mobilized community to participate in education?

d. How well is each form of participation functioning?

The first three questions are answered in the findings chapter by adopting Epstein's involvement framework. The last question is responded to in the discussion chapter using Bray‘s modified degrees of community participation framework.

\subsection{Scope of the Study}

This study is bounded by being located in a specific time and place, namely four schools in the Samlot district, Battambang province, Cambodia. The participants in this study were school directors, teachers, and School Support Committee (SSC) leaders from the four schools. Additionally, parents of primary school children from the four school communities and local authorities from the two communes (Tasanh and Sung) also participated. Only staff from two NGOs (World Vision Cambodia, Khmer Education Network) were included in the study. This study did not include the views of children. The study aimed at investigating the participation of community members in primary education within these four school communities only. It neither investigated the community participation above primary school level, nor participation beyond these four selected primary schools. The 
research was completed over twelve months from March 2015 to February 2016. The data collection period was between April and June 2015.

To be clear about the nature of the project, it is important to clarify my use of the term =community، Community in this study has two meanings: place and people. First, community refers to places where individuals, families and children live in relative proximity. Second, community refers to the people who live in the community (DeFilippis $\&$ Susan, 2008). These people are parents, individuals, local authorities, non-governmental organizations, business people, religious institutions, etc. To avoid any confusion between place and people, I use community member or community people to refer to people.

\subsection{Significance of the Study}

This study has two primary outcomes. The first is its contribution to the body of knowledge on community participation in education, specifically within the education sector in the rural context of a developing country, Cambodia.

This study also provides lessons on community participation in education for the different schools and communities. As a result, this information can be used to advocate for improving the quality of education at the primary school level.

\subsection{Overview of the Thesis}

This thesis consists of seven chapters. This first chapter provides an introduction to the research by bringing readers ${ }^{6}$ attention to the rationale, objectives and significance of the study. The second chapter deals with the context of the research. It provides details about the history and education policies with regards to community participation, and the linkages of the education context to relevant literature. The third chapter reviews the conceptual frameworks which are used for the study and the literature on community participation in education, particularly in relation to the development context. From this chapter, certain gaps in the literature are noted that have helped to frame this research. The fourth chapter provides the research methodology of the study. The fifth chapter deals with the analysis and elaboration of the research findings. The last two chapters, the sixth and seventh, provide discussions of the analyses and the conclusions are then drawn from them, and further discussion of the implications of these findings for the Cambodian context. 


\section{CHAPTER 2}

\section{POLITICS AND EDUCATION POLICY FRAMEWORKS}

\subsection{Introduction}

As described in the introductory chapter, this research was conducted to investigate community participation in education in four remote schools in Cambodia. To understand this question fully, it is important to consider local norms and the culture of the local community towards their participation in education. In addition, the culture of participation in education can be influenced by the policies and the systems of the society or the country. The understanding of the local context is also informative in analyzing and assessing the various forms of community participation in education. This chapter presents the context of the study, starting with a short profile of Cambodia and a brief discussion of the history and the system of education in Cambodia. After that, education law and policy with a focus on community participation will be outlined. The following section focuses on the local context of the specific area of this research project.

\subsection{Country Profile}

Cambodia, which has the official name of The Kingdom of Cambodia, is located in South East Asia. The total landmass is 181,035 square kilometers. The country shares borders with Thailand to the northwest, Laos to the northeast, Vietnam to the east, and the Gulf of Thailand to the Southeast (Chandler, 2015). The current population is 15.57 million with an annual population growth rate of $1.8 \%$ (UN, 2015). Life expectancy at birth (for both males and females) is 71.92 years (WB, 2015). Khmer is the majority ethnic group accounting for 90 per cent of the population. The other 10 per cent is composed of Vietnamese, Chinese, and tribal hill peoples. According to statistics from MoEYS (2015a), 51.36\% of the population are women, $19.5 \%$ of the total population live in urban areas, and the remaining $80.5 \%$ live in rural areas. 
Figure 1: Cambodian Map

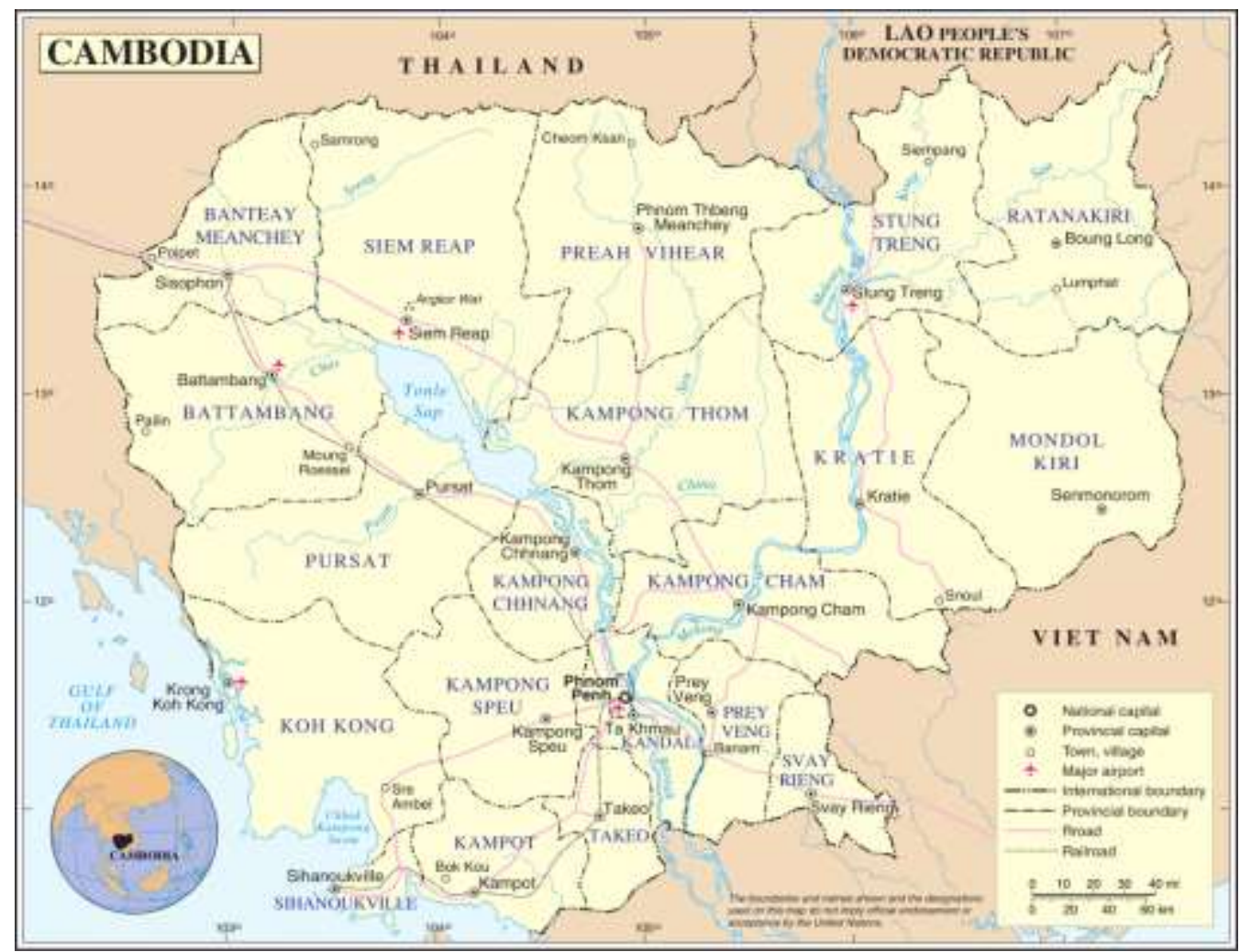

Source: https://en.wikipedia.org/wiki/Cambodia\#/media/File:Un-cambodia.png

\subsection{History of Cambodian Education}

In this section I briefly outline the history of education in Cambodia from the French colonization period (which began in 1863) until the current time. The description will be subdivided into five sections: education in the French colonial period; education in the post-colonial period; education during the Khmer Rouge regime; education in the 1980s and the current education development. The focus will be on the participation of the local people in education rather than education in general. Exploring the education history of the country provides information about local norms and culture of the local people in participating in education, which will establish a context for the focus of the research.

\subsubsection{Education in the French Colonial Period}

Before the French colonization period, participation in education was limited to boys only (Clayton, 1995, 2005). Cambodian boys were sent to get an education in the Buddhist 
pagoda schools (the Wat), provided by Buddhist monks (Pellini, 2005, 2007). Buddhist monks therefore played major roles in education. The education in the Buddhist pagoda was a traditional system in which a rote learning approach was applied, and there was no standard curriculum ${ }^{2}$ (Clayton, 1995). Students during this period learnt lessons by heart, memorizing and repeating them. The wat-school focused only on literacy. There was only reading and writing Khmer language" in the curriculum in the wat-school (Clayton, 1995).

In the mid- $19^{\text {th }}$ century, when Cambodia was under French colonial power, education was not widely available for the population. The French protectorate restricted education for Cambodian people because the French wanted to maintain their power over the colony (Clayton, 1995). Education, provided by the French protectorate, was only available for affluent families in urban areas. In the early 1900s, there were only four French-Cambodian schools with 290 students enrolled (Clayton, 1995). These schools were established to educate Cambodian people to assist with civil service work and the work of the colonial administration (Bilodeau, 1955; Quinlan, 1992 cited in Clayton, 1995).

Clayton contends that Cambodian leaders and people tended to be conservative with their culture (1995). Cambodian families tried to prevent their children becoming involved in the French education system, preferring to send their boys to pagoda schools because education in the wat-schools was intended to support social solidarity by "ensuring social cohesion and the maintenance of traditional values" (Quinlan, 1992, p. 8 quoted in Clayton, 1995, p. 2). Even though in 1918, the French administration tried to expand its modern education to rural areas (Pellini, 2007), they failed to achieve this because of the resistance of the Cambodian leaders and Cambodian families to accepting this education system (Ayres, 2000).

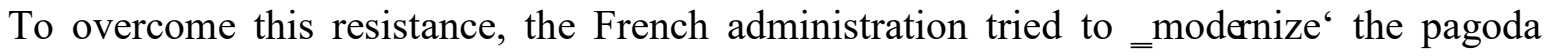
schools by recruiting students from the wat-schools to attend training in order to become teachers in their community. As a result, the French colonial administration earned acceptance from most community people and parents (Clayton, 1995). This, in turn,

\footnotetext{
${ }^{2}$ Only reading and writing Khmer (Cambodian language), principles of Buddhism, rules of property, and basic arithmetic were taught (Clayton, 1995).
} 
resulted in an increasing number of children enrolled in Franco-Cambodian schools ${ }^{3}$ (Clayton, 1995). According to Ayres (2000), in the academic year 1932-1933 there were only 225 temple schools. This number had increased to 908 by the academic year 19381939.

In summary, the culture of community participation in education has largely evolved since the French colonization period. Cambodian people in this period valued the education provided by Buddhist monks by sending their children to get education from the watschool, and they tended to ignore the French education system. This might be because the French protectorate in Cambodia introduced an entirely new model of education without consideration of the indigenous knowledge of the local people. The Cambodian community became more involved in education when the wat-schools were modernizing but were still keeping indigenous knowledge in the education system, which resulted in the participation of the community in this education system (Pillini, 2007).

\subsubsection{Education in the Post-colonial Period}

In the early 1950s, after gaining independence from France in 1953, King Norodom Sihanouk was very active in the country's politics (Pellini, 2007). He believed that education in Cambodia needed to be reformed. He realized the importance of education in developing a country, and that education had not widely reached the Cambodian population. Accordingly, in the national strategy, education was to be extended throughout the whole country, by building schools and education institutions, and by training teachers (Pellini, 2007). In this post-colonial era the country was limited in terms of resources and funds and the Government alone could not achieve this educational strategy. Thus, according to Pellini (2007), communities themselves significantly contributed to the extension of education in this period. Communities contributed money, labor and materials in constructing education institutions and schools. As a result, according to Pellini (2007), in 1955, there were 2,731 primary schools and ten secondary schools nationwide. The numbers increased, in 1968, to 5,857 and 180 respectively. Thus during this period, people

\footnotetext{
3 Franco-Cambodian school was a modern educational system, consisted of two types of education: elementary schools and full-course schools. Elementary schools provided a three-year education for children. The full-course schools consisted of three-year elementary education and three-year complementary education (Clayton, 1995).
} 
worked collaboratively together and with the government, and lived with peace and security, sufficient food, and good salaries for teachers" (Pellini, 2007, p.176).

The reform of education in this post-colonial period was very successful because of the collaboration between the government and communities. The culture of participation was valued and took place at the local level among community members. In addition, three main forms of participation in that period existed: financial, material and labor contribution.

By the mid-1960s, education in Cambodia was in crisis because of the conflict in the neighbouring country of Vietnam and because of the internal conflict with the Khmer Rouge. These challenges caused education to suffer because of the limitation of resources, particularly the destruction of human resources (Pellini, 2007). The conflict continued for several years and was exacerbated when Phnom Penh was taken over by the Khmer Rouge in 1975. The level of participation of the community in education was threatened because trust was lost among communities within Cambodian society (Clayton, 1995).

\subsubsection{Education in the Khmer Rouge Regime}

The Khmer Rouge, led by Pol Pot, seized Cambodia in 1975 and controlled the country until 1979. In this period, education in Democratic Kampuchea (as Cambodia was renamed) was utterly devastated. There was a complete absence of formal education during the time of this regime (Alabaster, 2014). School buildings, pagodas, institutions and other educational infrastructure were destroyed, abandoned, or used for other purposes (Clayton, 2005; Tan, 2010). The majority of educated people such as students, teachers and academics were evacuated to the rural areas and/or killed. The number treated this way was between $75 \%$ and $80 \%$ of all educated people (Geelves, 2002 cited in Pellini, 2007, p.113). About $67 \%$ of primary and secondary students disappeared during this period (Duggan, 1996).

In Democratic Kampuchea education took place on the farms, as stated in Clayton (2005):

the school is the rice paddy and the pen is the hoe' (p.509). This meant that children and young people were confined to farming in which they invested their entire time in the fields for material production. The leaders of the Khmer Rouge regime had ideological views on 
the advantages of education on the farm, rather than in formal schools, to build up the selfresilience of the country.

Trust was lost among communities in this period. People lived in horror and terror. Families were disconnected, communication was disrupted among communities. People could not share information, nor express their thoughts. Participation took place, but was defined in a very different way. People were forced to participate in field work without freedom of thought. As a result, the people who survived from this period were traumatized and needed long periods of time before being restored to normality (Clayton, 2005).

\subsubsection{Education after the Khmer Rouge Regime}

After the collapse of the Khmer Rouge, a new government was installed with support from the communist bloc countries such as the Soviet Union and Vietnam. The Cambodian government faced challenging tasks to restore the country from the state of devastation resulting from the Khmer Rouge regime. About 5,000 educators survived the upheaval and chaos, and about 1,000 of these were called back to work in the new education administration (Dykstra \& Kucita, 1997, p.2). New teachers were also selected from the citizens who could read and write in order to teach in the remaining schools and pagodas (Dykstra \& Kucita, 1997). The revival of education was a daunting task for the government to perform due to the lack of teachers, school buildings, basic teaching materials and necessary school facilities. This chronic challenge lasted for nearly a decade until the early 1990s.

During this period, there was a return to the participation and intervention of external and internal partners. In order to rebuild the education sector, the government welcomed the participation of educated people, and those who could read and write. In addition, the call also went out for participation from the communities to contribute to the re-establishment of education.

During this transition period, the harsh situation in the country calmed down in 1991 when the Paris Peace Declaration was signed (Clayton, 1995; Pillini, 2007). In 1993, under the support of the United Nations, free and fair elections were held for the first time in Cambodia. Noticeably, in the early 1990s, Cambodia attracted many external donors and 
financial aid agencies to help in developing the country. Millions of dollars flowed into the country through government agencies and non-governmental organizations (NGOs) (Pellini, 2007). According to Pellini, the number of NGOs increased subsequently (2007). The education sector gradually recovered, and continues to improve.

\subsubsection{Education Development in the Present}

Cambodia has demonstrated significant increases in human capital in recent decades. The country‘s Human Development Index (HDI) value doubled from 0.251 in 1980 to 0.584 in 2013, and it is currently ranked 136 (UN, 2015). However, in 2013, the Cambodian government only allocated 2.6 per cent of its GDP to education operations. Because of this tiny education budget, the country faces a huge challenge in terms of building human capacity. The education sector plays an important role in addressing this. On top of financing, the collaboration of the government through MoEYS and development partners, NGOs, private sectors and local communities, is pivotal in improving education (MoEYS, 2014a).

As shown in the annual report from MoEYS (2015a), the education sector has done very well with regard to Millennium Development Goal 2: education for all. The adult literacy rate had reached $82.8 \%$ in 2013 despite its relatively low level compared with the other countries in the region. Children start school at the age of six. All schools throughout the country are state-run with free access for all children to complete basic education.

The current statistics show that the total gross enrolment rate in primary schools in the academic year 2014-2015 is $111.2 \%$ (112.1\% for boys, and $110.2 \%$ for girls). The percentage exceeds $100 \%$ because of the inclusion of over-aged and under-aged children. This rate exceeds the education indicator in Millennium Development Goal 2, of the United Nations Development Program (MoEYS, 2015a). In the academic year 2013-2014, the promotion rate $^{4}$ was $86.5 \%$, repetition was $5.1 \%$, and the dropout rate was $8.3 \%$. This achievement is the result of the participation and contribution of national and international communities, development partners, local authorities, private sectors, parents, youth and

\footnotetext{
${ }^{4}$ - Pomotion rate is the proportion of students from a cohort (who enrolled in a given grade in a given schoolyear) who study in the following grade in the following school-year, while repetition rate is the proportion of students from a cohort enrolled in a given grade in a given school-year who study in the same grade in the following school-year" (MoEYS, 2015a, p.V).
} 
students (Naron, 2015). These figures indicate the participation of local authorities, local communities and education stakeholders in supporting education through sending children to schools and in providing support in material, money and time in education (Naron, 2015).

Despite these achievements, the current statistics from MoEYS (2015a) reveal inequality in education between urban and rural areas. The children in the urban areas outperform the children in the rural areas, and the children in the rural areas are more likely to repeat the same class and/or drop out compared to the children in the urban areas. According to the MoEYS (2015a), the enrolment rate in urban schools is $94.2 \%$ which is lower than in rural areas of $115.2 \%$. However, the promotion rate in the rural schools is lower than in urban schools with $85.8 \%$ against $90.6 \%$. In addition, the repetition and dropout rates in the rural schools are higher than in the urban schools with $5.4 \%$ and $8.8 \%$ against $3.7 \%$ and $5.7 \%$ respectively. These figures have drawn the attention of policy makers, policy advocates, educators, parents, communities and civil societies to the state of education in the rural areas, and challenge all concerned to close the gap between rural and urban education. To close this gap, the current minister of education continues to call all education stakeholders, especially local people in the rural areas, to pay close attention to education and to their children's education (Naron, 2015).

\subsection{Cambodian Development Objectives}

At the present, the country is attempting to transform itself into an upper-middle income country by 2030, and to be a developed country by 2050 (MoEYS, 2014a). The education sector plays a crucial role in achieving these outcomes in providing quality knowledge and skills to Cambodian children and young adults. Children are given free access to basic education in order to acquire knowledge and to maintain the culture of life-long learning. The education sector also provides vocational training including mechanical, information technology, secretary skills and agricultural skills to young people at the post-general education stage. Vocational training attempts to build up capacity to enable people to become part of the competitive workforce for the labor market at national, regional and global levels (MoEYS, 2014a). 
The Cambodian government, through the Ministry of Education, Youth and Sport (MoEYS), develops an Education Strategic Plan (ESP) every five years to frame its shortterm objectives. MoEYS started to develop Education Strategic Plans (ESP) in 2001, and to date, it has had five ESP cycles (2001-2005, 2004-2008, 2006-2010, 2009-2013, and 20142018). ESP has been developed to contribute to the National Strategic Development Plan (NSDP). In this mandate, MoEYS continues to carry on its vision and mission as follows:

The MoEYS vision is to establish and develop human resources of the very highest quality and ethics in order to develop a knowledge-based society within Cambodia.

In order to achieve the above vision, MoEYS has the mission of leading, managing and developing the Education, Youth and Sport sector in Cambodia in responding to the socio-economic and cultural development needs of its people and the reality of regionalization and globalization (MoEYS, 2015d, pp. 1-2).

Through these ESPs, the government sets out its ambition for the participation of the development partners and local communities in education (MoEYS, 2015d).

\subsection{Constitution, Law and Policy of Education}

This section will highlight important components of the Cambodian constitution, laws, policies and guidelines concerning education that shape education delivery today. The focus will be on participation in education. Understanding this legal and policy context is very important in analyzing community participation in education, because it shows the framework for people's participation in education from the top levels (policy makers) through to the grass root levels (policy implementers).

\subsubsection{Cambodian Constitution}

With the intervention of the United Nations, Cambodia's security situation became much more stable. As a result, the constitution of the Kingdom of Cambodia was enacted on the $21^{\text {st }}$ September, 1993 (RGC, 2008). It was in an amendment process until 2006, and so it was not until 2008 that it was officially promulgated. According to the constitution, all Cambodian citizens have equal access to basic education. The government is responsible for protecting and providing quality education to citizens for building human capital to 
support the country's prosperity. The constitution states implicitly that the contribution and the participation of basic education is free for all citizens for at least nine years, as stated in articles 65 and 68. Thus:

\section{Article 65:}

The State shall establish, protect and promote citizens' rights to quality education at all levels and shall take all measure, step by step, to make quality education available to all citizens.

Article 68: The state shall provide free primary and secondary education to all citizens in public schools. Citizens shall receive education for at least 9 years. The state shall help promote and develop Pali school and Buddhist institutes.

According to these two articles, all citizens have equal rights to access all forms of education which are operated by the government. Children can access education in the public schools from primary to secondary schools. Meanwhile, boys and men can access general education in the wat-schools (Pali school and Buddhist institutes) (Kim, 2014), which is equivalent to the general formal education in the state schools. This means that the Ministry of Education and the Ministry of Religion ${ }^{5}$ work in tandem to provide education services to religious monks in the wat-schools.

\subsubsection{The Education System}

Education is divided into three levels: primary education, secondary education and higher education (RGC, 2008). Furthermore, education is of two types: general education, and technical and vocational education. Primary school education consists of six grades (grades 1-6. Secondary education is divided into two phases: phase 1 is the lower secondary education which consists of grades 7-9 and phase 2 is the upper secondary education which consists of grades $10-12$. The basic education is defined by the combination of the first level of education (primary education) and the first phase of the second level (the lower secondary education). Thus, basic education consists of nine grades (grades 1-9).

\footnotetext{
${ }^{5}$ Name of one of Cambodian Government ministries (Ministry of Cult and Religion): http://www.mocar.gov.kh/
} 
The basic education provides formal general education. After the secondary education (grades 10-12 at secondary school), higher education consists of tertiary education at university and other institutes.

\subsubsection{Education Administration}

In order to ensure that education policies are well implemented and comply with the constitution, education law on education management and administration has been passed. Article 7 in Chapter III of Administrative and Management of Education in education law demonstrates that the hierarchy of administration and management of education has four levels: the national level, the provincial level, the district level and the educational institution level (RGC, 2007). The Ministry of Education, Youth and Sport (MoEYS) acts at the national level; the Provincial office of Education $(\mathrm{PoE})$ at the provincial level; the District office of Education (DoE) at the district level; and cluster school or schools at the educational institution level.

The table below shows the hierarchy of education administration in Cambodia from the national level to the educational level.

Figure 2: Hierarchy of Education Administration

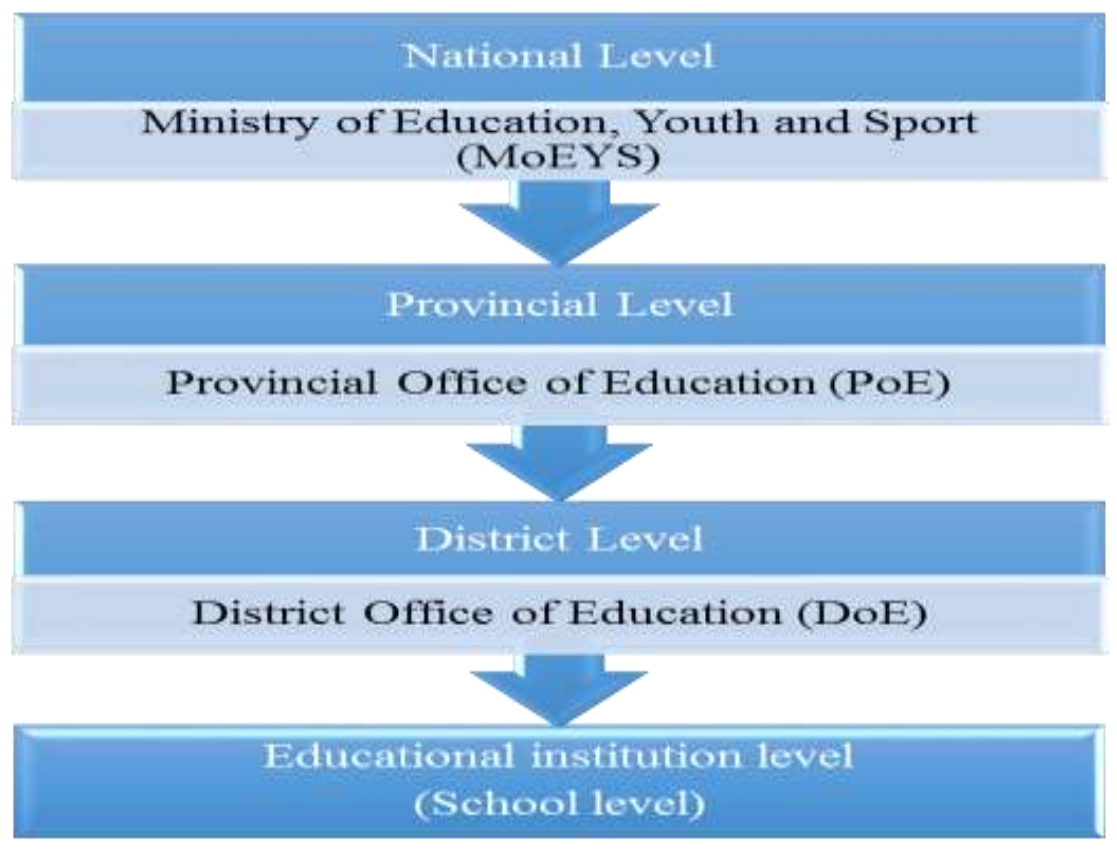

Source: Compiled by author, based on RGC (2007) 


\subsubsection{Policy at the Ministry Levels}

To support the enactment of the constitution, the Ministry of Education, Youth and Sport (MoEYS), plays a critical role in ensuring conformity to the constitution. Thus, the structure and system of education is set at the Ministry level.

In the Ministry of Education, Youth and Sport, education is composed of seven sub-sectors, namely early childhood education, primary education, secondary and technical education, higher education, non-formal education, youth development, and physical education and sport. These subdivisions enable the government to focus on the specific outcomes of each sub-sector. It also makes it easier to implement the project/program activities. This thesis is focused on primary education.

\subsubsection{The Encouraging Policy for Participation and Partnerships}

The government, through the MoEYS, sees the value of partnerships and participation from relevant stakeholders in improving education (RGC, 2007). The education law also legislates concerning for the participation and partnership for education. Thus, Article 29 declares that the state welcomes all kinds of support from the relevant stakeholders such as the public and private sectors, national and international organizations, non-governmental organizations, and communities (RGC, 2007). This Article encourages the involvement of these relevant stakeholders in the education process in such areas as planning, implementing, monitoring and evaluation. Article 36 and Article 40 mention the involvement of parents and/or the guardians in education. Parents or guardians have the right to choose education programs, to receive information and to study the records of learners, and to have active participation at school through their representatives (MoEYS, 2007a). They are under obligation to enroll their school aged children, to support their studies, and to maintain good relationships between families and community for enhancing education (RGC, 2007).

\subsubsection{Resource Mobilization}

Education administrators at all levels are strongly encouraged to mobilize resources for education development (as indicated in Article 44). Relevant stakeholders such as individuals, faith groups, families, communities, national and international organizations, 
non-governmental organizations, and public and private institutes, all have the right to participate and to provide resources in any forms such as financial, materials, technical, advice, labor and so on. Educational administrators have the right to mobilize legal resources from all sources in order to develop educational institutions or schools. The school leaders can mobilize resources in their communities to complement the school resources and the budget received from the government. However, the contribution (financial and materials) from communities is voluntary (RGC, 2008).

According to the MoEYS, educational institutions and schools have different sources of income and funding in addition to the government funding, called Planned Budget (PB), which is delivered to the school annually. The diagram below shows the common sources of income that the schools have (MoEYS, 2015a).

Figure 3: Sources of funding of the schools

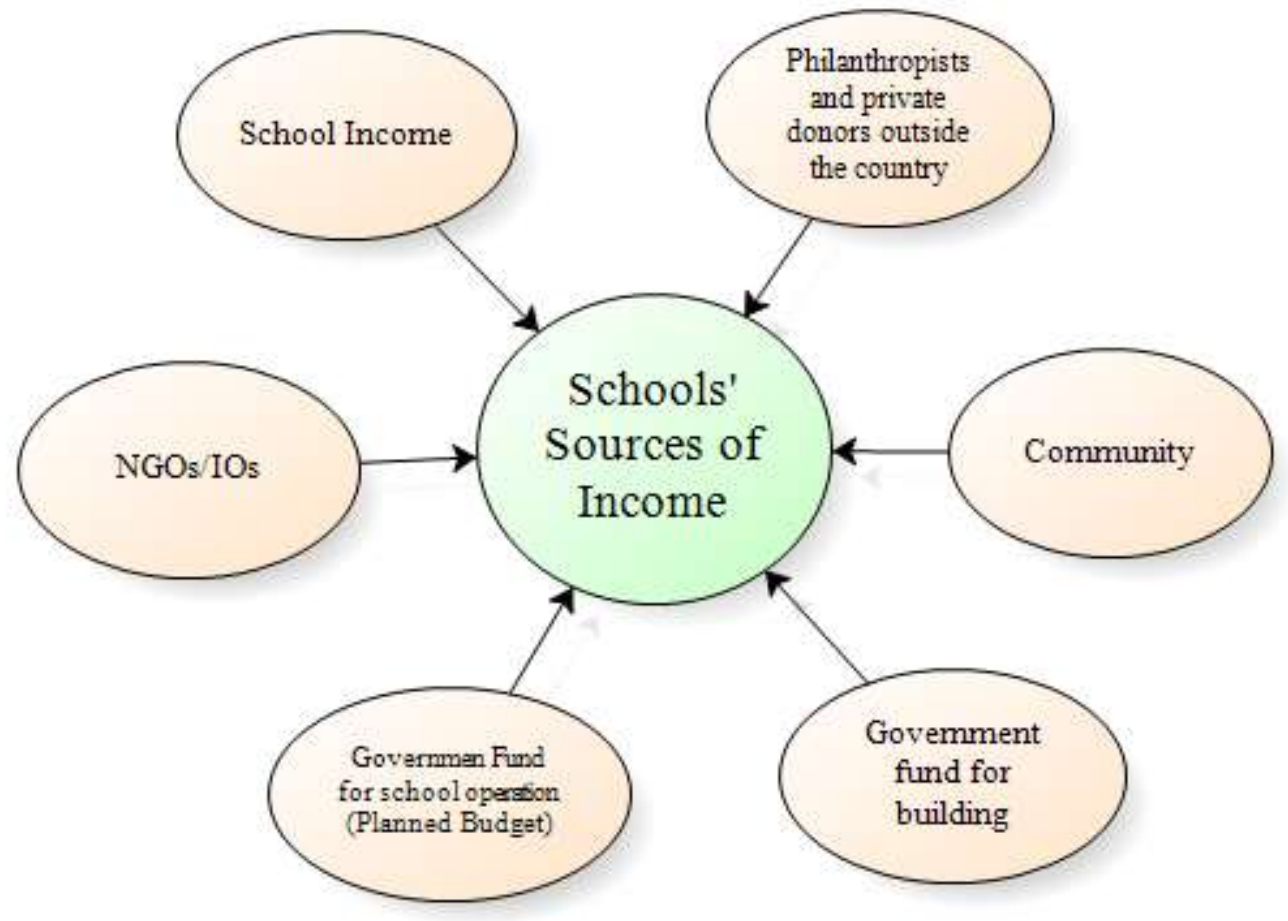

Source: Compiled by author, based on MoEYS, 2015a 


\subsubsection{School Clustering Model and Decentralization in Education}

In order to address imbalances in education between schools, the innovation of school clusters was piloted by UNICEF in 1993 in four provinces, by grouping schools that are located near each other (Clayton, 1995). The school clustering approach aims at promoting school ownership among students, parents and local educators through decentralizing authority and by encouraging community participation in decision making (Dykstra \& Kucita, 2007). Strong schools and disadvantaged schools are grouped together in order that the former can help the later in terms of sharing resources (Bredenberge, 2002).

Figure 3 depicts the model of cluster school. A cluster school consists of a core school, which is a central school, and between four and six satellite schools. The core schools and satellite schools are complete schools, consisting of six grades from grade 1 to grade 6 . In some cases, satellite schools may have annex schools which are incomplete schools and do not have all six grades (MoEYS, 2015a).

Figure 4: School Cluster Structure

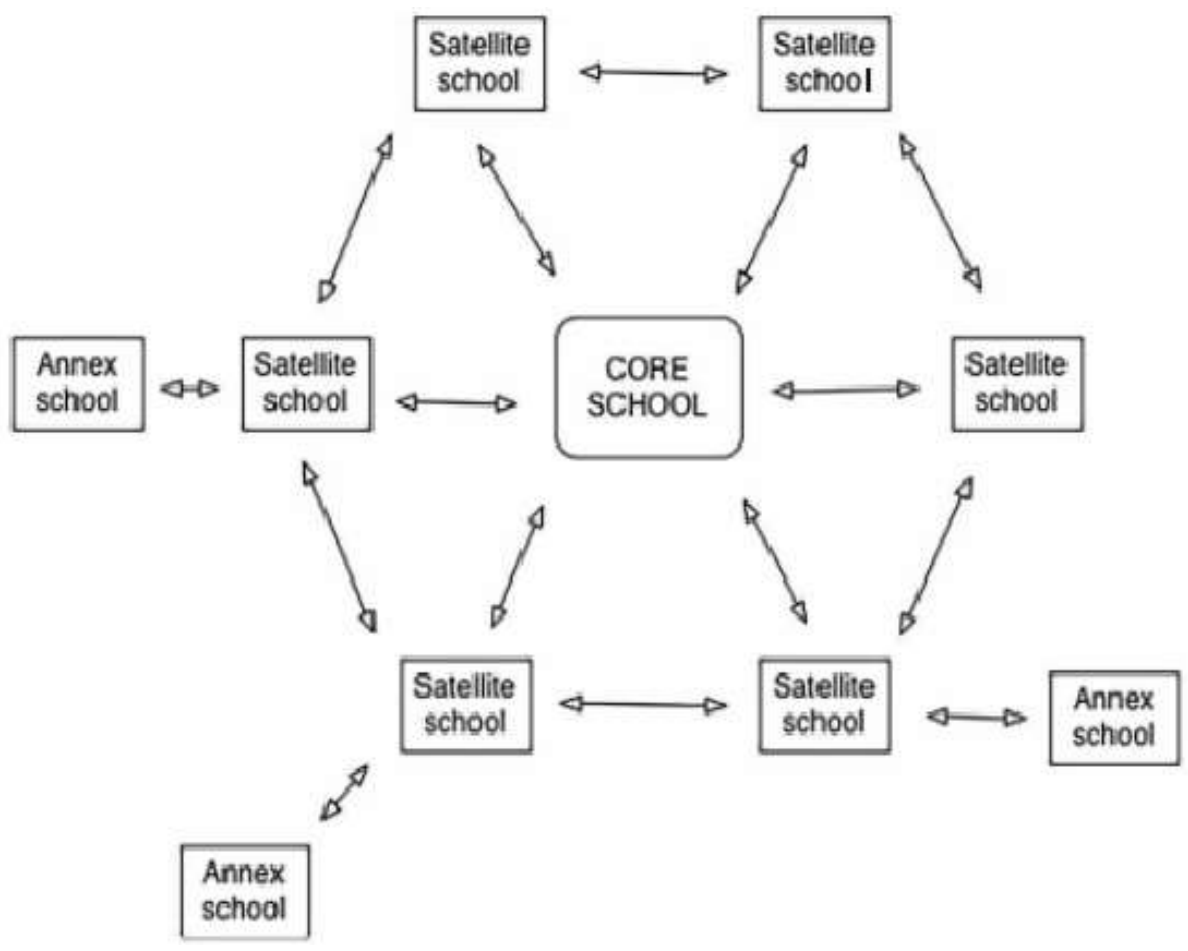

Source: Pellini \& Bredenberge, 2015, p.421 
The school cluster concept has four main objectives: economic, pedagogical, administrative and school-community objectives (Dykstra \& Kucita, 1997). First, it is created to provide economic assistance to the schools within the cluster by creating resource centers for storing resources such as equipment and teaching and learning materials which can be accessed by all teachers from the schools within the cluster. Secondly, this approach provides pedagogical support to teachers in the clusters. Teachers can have regular meetings to share knowledge and the best practice with regard to effective teaching and learning. This can be a part of the in-service learning of the teachers. Third, the cluster school can assist the work flow and communication process by working with the cluster head instead of every school director in such matters as planning, monitoring, and in the evaluation and management of the education program. This can minimize paperwork and bureaucracy at the school level. Finally, the cluster concept aims at connecting the school and community. Thus it allows community representatives to get involved in the schooling process such as classroom monitoring and the sharing of local knowledge to the class (Dykstra \& Kucita, 1997).

According to this last objective, the school cluster approach contributes to the promotion of community participation. The school-community objective is concerned with the formulation of Parents and Teacher Associations (PTAs) for the clusters (Dykstra \& Kucita, 1997; Pellini, 2007). In the Cambodian context, parents and community people traditionally contribute in school construction, renovation, maintenance and in looking after

the school properties (MoEYS, 2012). The involvement of parents and community people at the beginning of the cluster formulation creates trust among families, school staff and local authorities. This involvement, according to Dykstra and Kucita (1997), has also helped to heal the nation from a long civil war in which trust among people was lost. Furthermore, the involvement of families in schools promotes accountability and transparency in resource mobilization and budget management within the schools.

\subsubsection{Child Friendly School Policy}

In order to improve the quality of education, MoEYS adapted, at the beginning of the 2000s, the concept of Child Friendly Schools from UNICEF (MoEYS, 2007). Consequently, in 2007, the MoEYS developed a Child Friendly School (CFS) policy in basic education for all schools throughout the country. The objectives of this CFS policy 
are to implement child rights, to strengthen the quality and effectiveness of basic education, to apply the decentralization system, and to support the Ministry in achieving the aims of Millennium Development Goal 2 of education for all (MoEYS, 2007). The MoEYS's Child Friendly School framework which was adopted from UNICEF has six dimensions. 1: all children are to have access to schooling (inclusive); 2: improve effective teaching and learning; 3: enhance the health, safety and protection of children; 4: gender responsiveness; 5: to ensure the participation of children, families and communities in education; and 6: to help the management support for schools to become more child-friendly (MoEYS, 2007).

It is important, for the purposes of this thesis, to highlight the fifth dimension that various forms of participation in the school are encouraged. The CFS framework identifies key activities for all schools to apply in relation to participation, such as community participation in collecting children in the community for school; community resource mobilization activities such as fund raising; forming representative groups in school; including families and communities in school activities, and so on. To contribute to this framework, and in the light of the education law stated above, the MoEYS have developed guidelines for all primary schools to have School Support Committees (SSCs) and Student Councils to support school operations.

\subsubsection{School Support Committee (SSC)}

The School Support Committee (SSC) is an organization to represent community members and parents in the schools (MoEYS, 2012). This organization is supposed to ensure a smooth, transparent, accountable and effective education process. They are involved in formulating, implementing and monitoring the school plans; collecting and enrolling children in school; monitoring student's learning; generating revenue and mobilizing funds. The SSC is also involved in constructing, repairing and maintaining schools; sharing experience and life skills; safeguarding properties inside and outside the schools; strengthening and expanding the capacity and awareness of school development. In addition, the formation of this group aims to help to protect and develop the schools, as well as increase cooperation and facilitation among communities.

The members of the committee come from different stakeholder groups such as local authorities, monks, school directors, the elderly, pagoda committees, parents, laymen, 
education officials and private donors (MoEYS, 2012). These people are volunteers, without any incentive of being paid. According to the guidelines, the honorary chairperson should be a local authority or head monk and the advisor should be a school director or retired education official. The chairperson should be a retired education official, a pagoda committee member, a layman, a private donor or a parent. The deputy chairperson and committee members could be any of the people mentioned above.

This section can be summarized with the conclusion that the Cambodian government is encouraging community participation in all levels in education. This is indicated in the constitution and education policies.

Figure 5: School Support Committee Structure

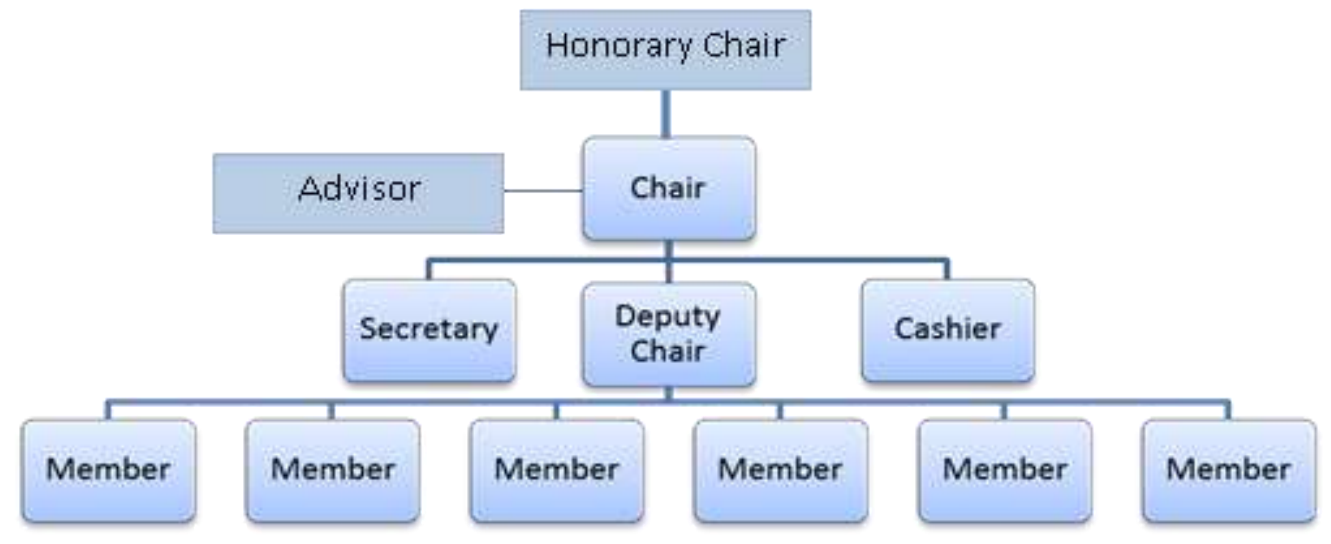

Sources: Compiled by author, based on MoEYS, 2012

\subsubsection{Student Council (SC)}

The Student Council (SC) is formed to assist school administrators and teachers in school administration. Student Council members are representatives of students in the school and in the communities. Class representatives from each grade (grades 3-6) are nominated to stand for election. At the beginning of the academic year, the SC leader and committee are elected. Every SC committee has different roles and duties to implement. Such tasks and roles include administration, social work and protection, education and care of the library, disciplinary matters, and work related information, environment and resources. In addition, the student group has regular meetings with its members and school administrators (interviews with school directors and observation). 
Figure 6: Student Council Structure

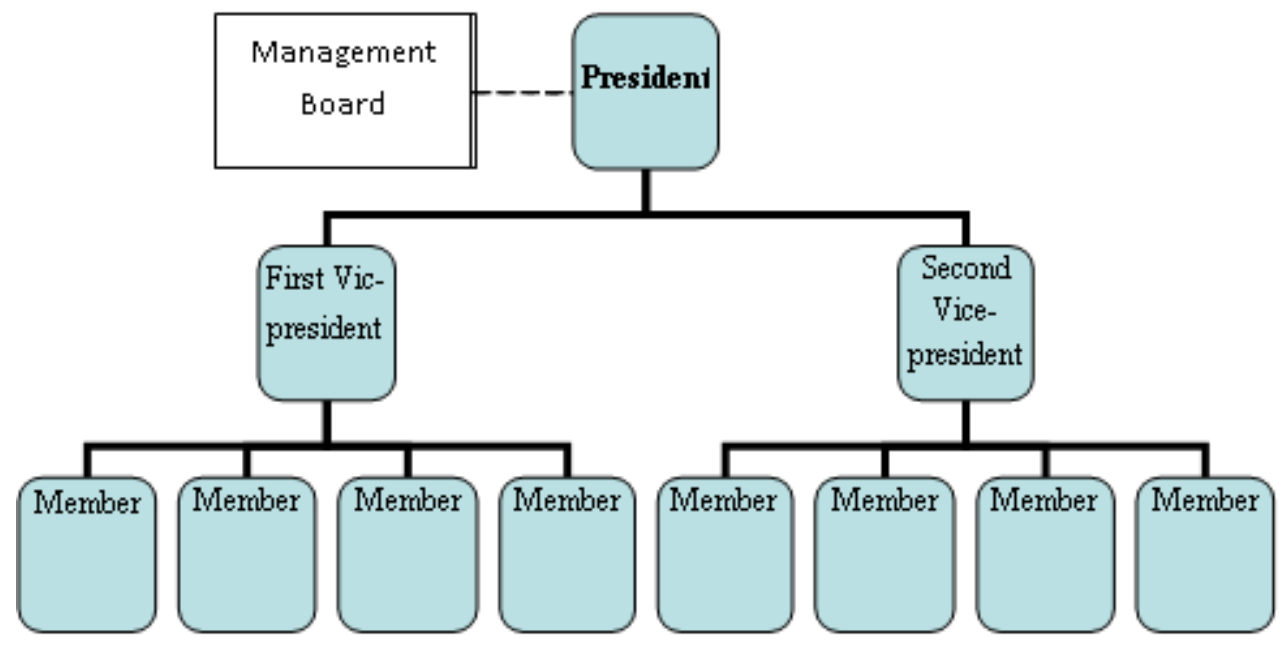

Source: Compiled by author, based on MoEYS, 2012

\subsection{Research Area}

This section will provide background information about the physical geography and the situation of education in the research area. This information is crucial as the distance of villages to the schools, and the community layout, affects the participation of the community in education. In addition, the livelihoods of people may be a motive for participation or non-participation. Furthermore, an understanding of the information in this section about enrolment, promotion, repetition and the dropout rate informs data analysis and the discussion in later chapters.

\subsubsection{Battambang Province}

Battambang province is the second largest province in the western part of the country. It is approximately $228 \mathrm{~km}$ from the capital city, Phnom Penh. The province consists of fourteen districts. There are 218,843 families and 1,071,209 persons in the province (MoI, 2010). Most of these people (80.68\%) rely on agriculture as their main source of income. The rest are engaged in craft work, livestock farming, and services (16\%) (MoI, 2010). 
Figure 7: Map of Battambang Province

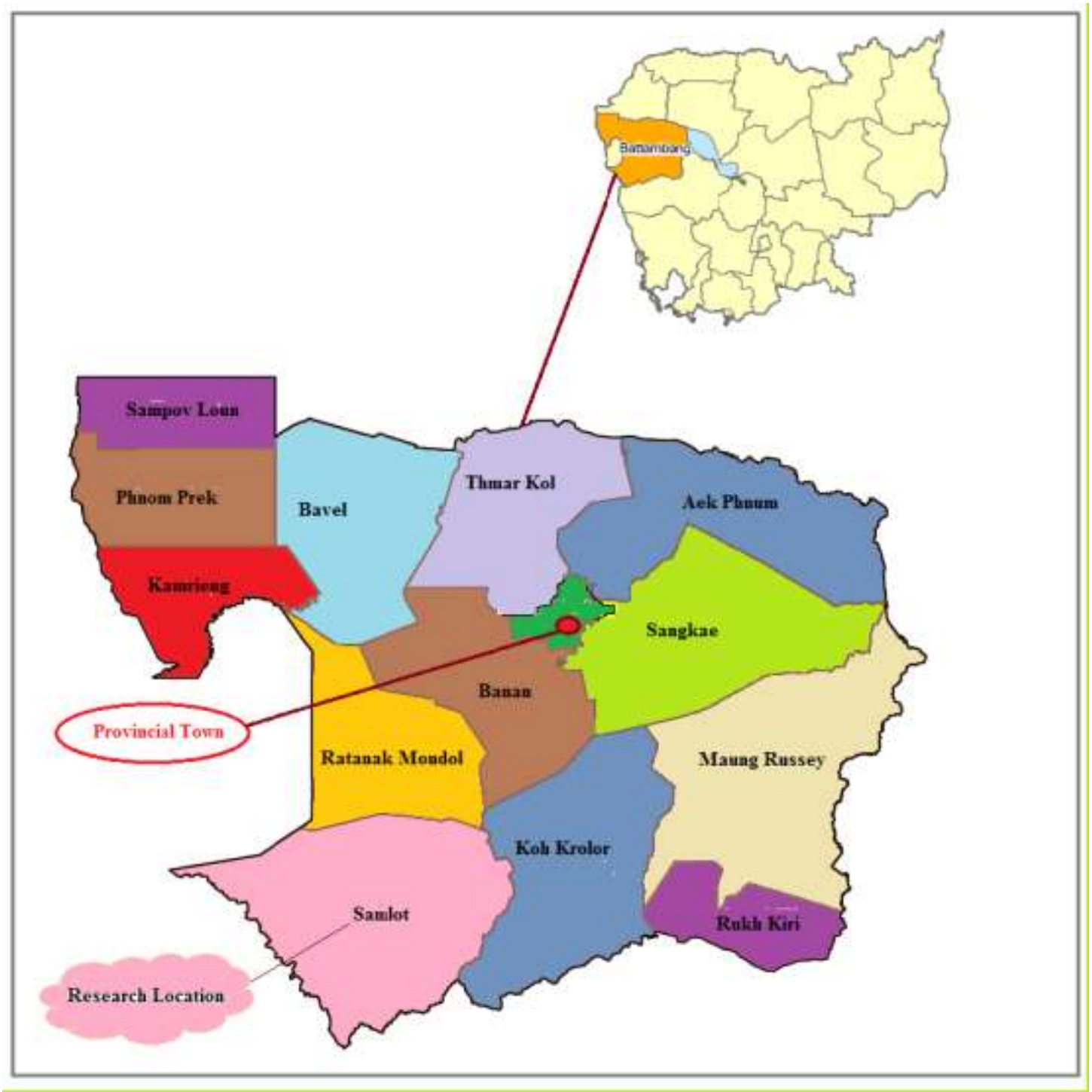

Source: Compiled by author, based on RGC, 2012, p.20

The education report in the academic year 2013-2014 shows that the promotion rate in the whole province was $83.00 \%$ ( $84.80 \%$ for girls); the repetition rate was $5.10 \%(4.20 \%$ for girls); and the dropout rate was 11.80\% (11.00\% for girls) (MoEYS, 2015b). The net enrolment rate in the whole province in the academic year $2014-2015$ was $96.8 \%$ (97\% for girls) (MoEYS, 2015b).

\subsubsection{Samlot District}

Samlot where the study was conducted is one of the most remote districts of Battambang province being about 80 kilometres from the provincial town. The district stretches over 
180,300 hectares of which around 80,181 hectares are forest, 55,200 hectares are cultivated land, and 6,410 hectares are residential land (MoI, 2010). The district is connected to the provincial town by the national road 10 . The road is in a bad condition. The first half of the road is concrete, but the second half is a dirt road which is bumpy, slippery, and dusty. The common modes of transportation from the provincial town to the district are bus, taxi and motorcycle. It takes about one and a half hours to travel by taxi and bus, or about two hours by private motor bike, from the provincial town to the district.

Figure 8: Map of Samlot District

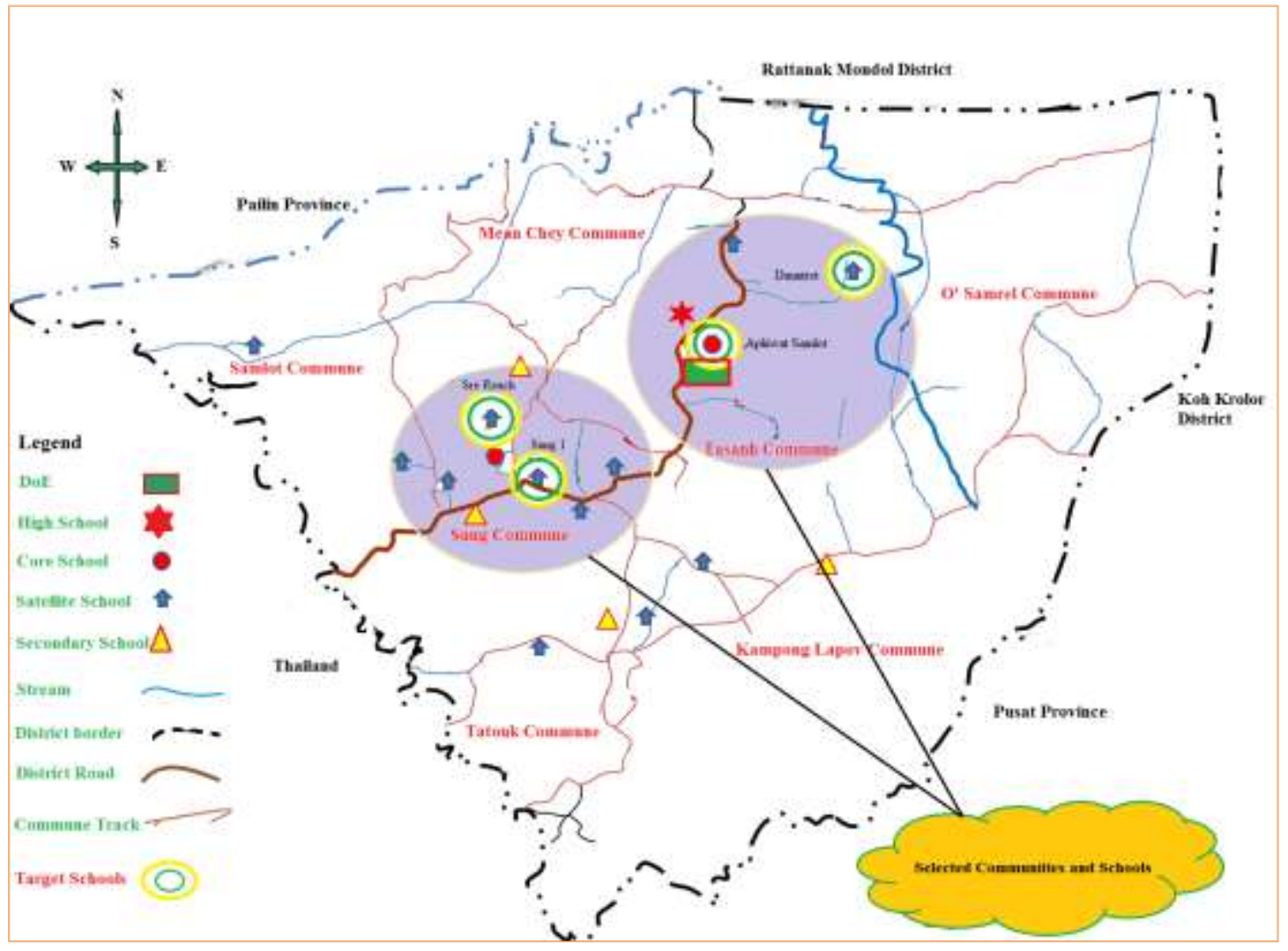

Source: Compiled by author, based on Samlot DoE, 2015

There are seven communes in the district. Based on the Commune Data Book 2015, the district has 10,599 families and 44,621 persons (MoP, 2014a). The average family size in the district is fairly small, at 4.2 . The statistics shows that $84.3 \%$ of the families rely on agricultural farming as their primary source of income. Based on the Ministry of Planning, 
$31.4 \%$ of households within the district are in the poverty criteria ${ }^{6}$ (poor $1: 10.6 \%$, poor 2 : $20.8 \%$ ) which equates to $45.4 \%$ of the population being poor people (RGC, 2012).

The most common means of transportation in the district are motorbikes. Children in the district go to school on motorbikes and bicycles, as well as on foot. Farmers use hand-held walking tractors known as Kor Yun as the means to transport their agricultural produce to the market.

According to the statistics from the DoE, Samlot district has forty primary schools which are grouped into eight clusters (DoE, 2015). As mentioned above, the school clustering approach is adapted nationwide in order to assist schools in consolidating and sharing local resources. Every primary school within the district has different characteristics and geographical layout. Some schools are on the main road and some are off the main road with scattered households. School buildings are also in different conditions. Of the forty schools, there are forty-five concrete buildings and twenty-four wooden buildings ${ }^{7}$ (DoE, 2015). Twelve school buildings do not have a proper roof ${ }^{8}$, thirteen do not have proper floors ${ }^{9}$, thirteen do not have proper walls, and four buildings are very old (DoE, 2015). The poor school conditions, and the proximity of the households to the school, are likely to influence the participation of children in schools and the participation of the community in education.

According to the currently available statistics, there are 6,827 children aged between six and fifteen years in the district. In the academic year 2013-2014, the overall promotion rate at primary school level in the district was $80 \%(82 \% \text { for girls })^{10}$, the repetition rate was $6 \%$, ( $4 \%$ for girls), and the drop-out rate was $15 \%$ (14\% for girls). The net enrollment rate for the academic year 2014-2015 is $101.3 \%$ (104.6\% for girls) (MoEYS, 2015b).

\footnotetext{
${ }^{6}$ The Identification of Poor Household (ID Poor) was conducted to identify poor household so that the government agencies and non-government organization can provide service to the poor to lift them out of poverty. The ID Poor assessment criteria are housing; assets; livestock; transportation; active members; income generation and food security. There are three poor category: Poor $1(59-68$ point $=$ very poor), Poor 2 $(45-58$ points $=$ poor $)$ and other $(<45$ points $=$ not poor $)($ RGC, 2012, p.5)

(Retrieved from http://www.idpoor.gov.kh/Data/En/Reference/IDPoor_ATLAS_Round 4 5 5_Eng-FINAL.pdf

${ }^{7}$ The buildings were made of local wood as contemporary buildings for teaching and learning.

${ }^{8}$ The buildings are leaking when raining.

${ }^{9}$ No tile floor

${ }^{10}$ Achievement rate means the rate of children promoted to the next grade in the new academic year.
} 
Figure 9: Comparison of education statistic

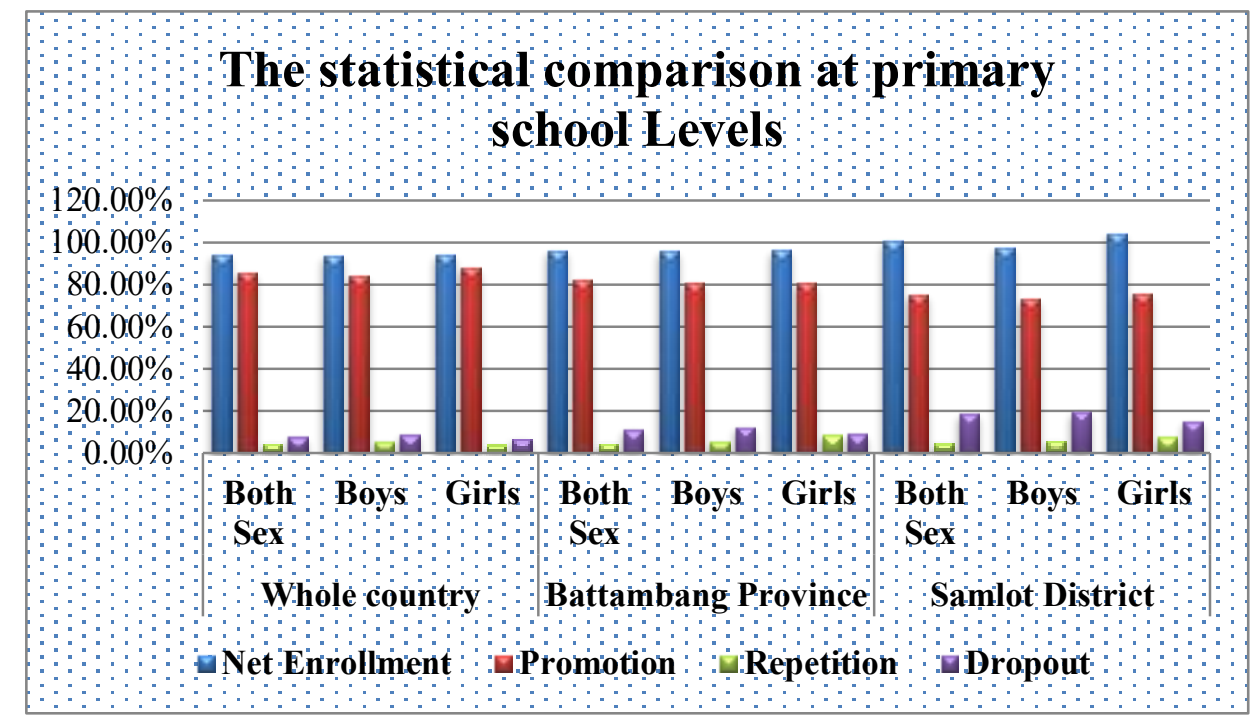

Source: Compiled by author, based on MoEYS, 2015a

This bar graph compares the education statistics at three levels in terms of enrollment, dropout and promotion: national, provincial and district level. The graph shows that the enrollment rate at the district level stayed at the top of the graph. In contrast, the promotion rate was the lowest and the dropout rate was the worst. This graph draws the attention of the MoEYS to the education performance in this district and they follow up by investigating the reasons for the high dropout rate. According to Save the Children Cambodia, students had more absences and dropped out of schools because their families move around a lot and they have poor living conditions (2015).

\subsubsection{The Four Selected Schools}

This case study selected four primary schools from two school clusters: Aphiwat and Sung 2 cluster (See Table 1). Aphiwat school cluster, which is in Tasanh commune, consists of four schools: Aphiwat Samlot (a head school) and three other satellite schools - namely Dauntret, Prey Romchek and Sahakum Dauntret. Sung 2 cluster, which is in the Sung commune, has four primary schools -Sung 2 is a cluster head school; Sung 1, Sre Reach and Santepheap primary school are satellite schools. Aphiwat Samlot and Dauntret primary schools are in Aphiwat school cluster and Sung 1 and Sre Reach primary schools (also selected) are in Sung 2 school cluster. 
Table 1: Selected Schools for the Study

\begin{tabular}{|c|l|l|}
\hline Cluster & \multicolumn{1}{|c|}{ Name of Schools } & \multicolumn{1}{c|}{ Remark } \\
\hline \multirow{4}{*}{ Aphiwat Cluster } & Aphiwat Samlot & Selected schools \\
\cline { 2 - 3 } & Prey Romchek & \\
\cline { 2 - 3 } & Dauntret & Selected schools \\
\cline { 2 - 3 } & Sahakhum Dauntret & \\
\hline \multirow{4}{*}{ Sung 2 Cluster } & Sung 2 & \\
\cline { 2 - 3 } & Sung 1 & Selected schools \\
\cline { 2 - 3 } & Sre Reach & Selected schools \\
\cline { 2 - 3 } & Santepheap & \\
\hline
\end{tabular}

\section{Aphiwat Samlot}

Aphiwat Samlot primary school is located in the centre of the district and it is next-door to the District office of Education (DoE). The distance from the school to the District Hall is 2 kilometers, the distance to the commune hall is 2 kilometers. There are two villages in the school's vicinity - namely O'Totem and O'Sgnuot. The average distance from the villages to the school is 1.66 kilometers. Children of primary school age from these two villages attend Aphiwat Samlot primary school (DoE, 2015).

\section{Dauntret Primary School}

Dauntret primary school is a satellite school of the Aphiwat cluster school. This school is located off the main road. The distance to the Tasanh commune hall is 11 kilometers, and the distance to the district hall is 12 kilometers. Dauntret is a complete school with two buildings and five rooms, and four teachers (two of whom are female). There is only one village in this school's vicinity, Dauntret village. The average distance from village to school is 1.66 kilometers. This village has 453 families with a population of 1,882 people (992 females) (DoE, 2015).

\section{Sung 1 Primary School}

Sung 1 is a satellite school of the Sung 2 cluster. Sung 1 primary school is located along the main road and is about 1 kilometer from the Sung commune hall, and about 20 kilometers from the district hall. Sung 1 has two buildings (with seven classrooms), one wooden and one concrete. There are nine teachers (seven of whom are females). There are two villages 
within the school's vicinity -Sung 1 and Chamkar Chek villages. The average distance from the villages to the school is 1.08 kilometers (DoE, 2015).

\section{Sre Reach Primary School}

Sre Reach primary school is in the same cluster as Sung 1 primary school. It is located off the main road. Sre Reach primary school is about five kilometers from the Sung commune hall and about 20 kilometres from the district hall. The school has three concrete buildings and 11 classrooms with 14 teachers (five of whom are females). There are two villages within the school's vicinity - namely Sre Reach, Kandal and Ponlok villages. The average distance between school and village is 1.08 kilometers (DoE, 2015).

\subsection{Conclusion}

The participation of the community in education has changed over time in Cambodia. Traditionally, Cambodian people participated in education through the wat-schools, as this traditional education was cohesive with Cambodian society. The participation of the community in education occurred through contributing available resources for school and education development. This chapter has discussed how community participation in education decreased dramatically due to the conflict and civil war in the country. Cambodian people experienced traumatic events that caused the loss of trust among community members.

In the last two decades and with the arrival of peace in the post-conflict era, the participation of the community in education shows an encouraging increase. The increasing community participation in education appears to be the result of both policy interventions and the collaboration among local people and governmental organizations, as will be further discussed in this thesis. It is clear that the constitution, education law, education policies and guidelines all encourage the participation of the community and other partners in promoting and supporting education. The five components of the Child Friendly School policy framework is an example of the focus of the government on community participation in education. 
Despite the description in the chapter of community participation in education in Cambodian history and recent policy interventions, the concepts and frameworks of participation and community participation in education have yet not been explored in depth. The next chapter will examine the literature on community participation in education in detail. 


\section{CHAPTER 3 \\ LITERATURE REVIEW ON COMMUNITY PARTICIPATION IN EDUCATION}

\subsection{Introduction}

The previous chapter showed how the Cambodian government has been promoting participatory development approaches in the education sector. Those indications are evidenced in the education policy frameworks at the national levels, for example the fifth component of the Child Friendly School policy is community participation. Another indication is the inclusion of local people in education development through the School Support Committee (SSC) which is a formalized community structure at the schools. Given the specific focus on the Cambodian context, the chapter did not engage with broader literatures and frameworks of community participation in education. This chapter addresses these issues.

This chapter will unpack the literature in community participation in education and community mobilization methods. In particular, Epstein's participation framework and Bray's degrees of participation framework, which are used in this study, will be reviewed. Prior to determining these two frameworks, the chapter will briefly discuss key concepts of development, and highlight typologies of participation. Community mobilization will then be discussed, before a discussion of recent studies on community participation in education in the Cambodian context. The gap in literature in community participation education will be identified in the last section of the chapter.

\subsection{Key Concepts in Development}

This section briefly engages with the concept of development and unpacks key terms concerning participation, community and community participation. 
Development is defined as the betterment and freedom of human-beings and it is a state of improved wellbeing of individuals, families, communities and societies (Cowen \& Shenton, 1995). The concept of modern development is said to have emerged after World War II when in 1947 US President Harry S. Truman advocated technical assistance to the allies and the extension of development assistance to the Third World (Cowen \& Shelton, 1995). Truman's idea about development emphasized making improvements, modernization, growth, and development in those _undeveloped' and _developing' countries. This development during that post-war period focused on economic growth at the macro level and using top-down approaches (Desai \& Potter, 2014). The aim of development was initially to reconstruct the allied countries' ${ }^{6}$ economies from the destruction of World War II, after which technical assistance was extended to both other developed and developing counties, largely in exchange for political allegiance.

In more recent decades alternative development approaches have focused on the improvement of the lives of local people at the local level through processes in which local people are included (Mohan \& Stokke, 2000). Local communities share roles and responsibilities in planning, implementing and evaluating development projects in their communities (Chambers, 1994). Participatory development emerged and became the focus of governments and development agencies. Many studies have shown that the community participation approach can enhance ownership, sustainability and success in development (Chambers, 1994; Pretty et al., 1995). Community participation is not only used in social development, but also in education development. A number of studies report that the participation of the communities in education can enhance children's learning (Epstein, 2006; Griffin \& Steen, 2010; Sheldon, 2007; Shanders, 2001).

\section{Participation}

Participation is generally understood as the involvement of agencies from both inside and outside a community to work together in development projects for common interest (Cornwall, 2006, 2008; Mohan \& Stokke, 2000). Participants can be relevant stakeholders who have influence and share control over development initiatives and communities and the public (Nelson \& Wright, 1995). However, Swanepoel and De Beer (2006) argue that participation does not exist unless people are mobilized to be part of decision making, 
planning and project management including implementation, monitoring and evaluation. Participation can occur in direct and indirect forms. In the former form, community participate in the development program, whereas in the latter community participate through their representatives such as committees, associations and clubs (Save the Children Cambodia, 2015). Arnstein (1969), Crocker (2007) and Pretty et al. (1994) relate participation to power in decision making. These three researchers suggest that people can be _participants “ even just by listening at meetings but they classify them as _passive participants' (Pretty et al., 1995) because they have no chance to speak. On the other hand, real participation is the process in which real power in decision making lies with the participants (Bray, 1999, 2001).

Participation in this study is the involvement of communities, children, parents, teachers, local authorities and education relevant stakeholders in enhancing children's learning (Epstein, 2006). Their participation can be in direct or indirect forms and may occur at schools, at home and/or in the community (Save the Children Cambodia, 2015). Using education services is also counted as participation (Bray, 2001). Their relationship to _power' in decision-making will be discussed in the findings and analysis chapters later on.

\section{Community}

Community is defined as a geographical area that consists of people who have social interaction and have one or more commonalities (Hillery, 1955). This contention is still valid and agreed by most theorists (DeRienzo, 2008; Epstein, 1995; Garcia, 2011; Rose, 2003; Wolf et al., 1997). Not only is a place referred to by _community‘, but also people and institutions in the community (DeFilippis \& Susan, 2008). DeFilippis and Susan (2008) suggested that _community ${ }^{6}$ is inclusive of people and places as people, places, and institutions that we encounter everyday life provide opportunities and support for our activities, as well as barriers and constraints" (p.1).

The Cambodian community in the past had strong connections with Buddhist pagodas as the social, cultural and religious centre of the community (Pellini, 2005). This behavior is still practiced in the Cambodia society of the present. The Cambodian community, according to Clayton (1995) and Pellini (2005), is socially hierarchical in which elderly are 
highly respected. Village leaders, laypeople, rich families and community members who are literate are reported as community leaders (Pellini, 2005).

In my research community ${ }^{6}$ refers to a fairly diverse group of education related stakeholders who have a collective purpose. This includes parents, local authorities, civil societies, community based organizations, NGOs, business people, microfinance institution, youth, churches, Buddhist pagoda, and other private institutions. These people and institutions which are visible in the community may or may not have a chance to be involved in education in school, at home or in the community.

\section{Community participation}

Based on the discussion of participation" and -emmunity" above, community participation is the circumstances in which individuals in the community are involved in the development processes in all levels of society through active contribution and for the purpose of sharing the benefits from development (Vandana, 1995). Community members participate in sharing responsibilities over development initiatives, decisions and resources which affect them (Nelson and Wright, 1995, p5). They (community members) also participate in development projects/programs through their representatives or directly participate in development activities (Arnstein, 1969; Pretty et al., 1995; Crocker, 2007). In short, community participation in the development refers to the process of including local people, families, local authorities, community leaders, development workers, and development professionals in the process of identifying problems, the planning, implementation, monitoring and evaluation of the development project in the community.

In the research context, to be more specific, community participation in education is the involvement of parents and communities in supporting children's learning at home, schools and in community (Swift-Morgan, 2006).

\section{Power}

The concept of power has connection with community. According to DeRienzo, power exists when people gather as a community and/or work together; in contrast, power vanishes when people are separated (2008). People gain power when they participate for a 
collective purpose. This means that power is closely connected with the participation of the people. To gain power in the development, community people form groups and community organisations. For example, community, local authorities and parents form school-familycommunity partnerships (Epstein \& Salinas, 2004) and Parent-Teacher Associations (Pang, 2004). Thus, power exists in everyone, and it is used in different ways; the power of the individual is weak, but can gain power when people are collective.

Power is always negotiable (Sultana, 2007). In power dependence theory, "the power of A over B is equal to and upon the dependence of B upon A" (Fragale et al., 2005, p801). Power can be increased and decreased depending on how people exercise power. One's power increases when his/her counterparts' power decreases. Thus, power has to be adjusted to the situation through negotiation. To negotiate power, Fragale et al. (2005) suggest consultation techniques to their participants. In the consultation technique, people interacted with one another in the discussion and decision-making.

\subsection{Politics of Participation}

A number of researchers have developed typologies of participation in order to highlight the different forms that participation can take, from passively participating and being largely _co-opted' into a process, through to being politically empowered through taking ownership of the process. Those typologies include ladders of citizen participation (Arnstein, 1969), typologies of participation (Pretty, 1994), degrees of community participation (Bray, 2001) and participation frameworks (Epstein, 2006). The first two typologies were created to serve generally in the development context and the last two were for the education context specifically. Bray's framework and Epstein's framework will be discussed later in this chapter.

Sherry R. Arnstein developed a Ladder of Participation to determine the levels of power of participants in the participation processes (1969) as shown in Figure 10 below. Arnstein argued that participants have different levels of power and each level of power is unequal in terms of strength and influence (1969). Arnstein put the eight types of citizen participation into three categories. First, nonparticipation' consists of two types, manipulation“ and =therapy 6 . People in this category are considered as non-participants because they do not 
intend to participate. Shaeffer describes this category as an involvement stage where these unintended participants are told or asked to be involved by outsider experts or researchers (1994). Arnstein's second category is degree of tokenism" which consists of three types, =informing', =consultation', and _placation'. Participants gain power when they move up to this category. They have voice, and their voices are heard to some extent. However, they are still influenced by powerful people. Participants are able to provide inputs or feedback although power still lies with the elites. Arnstein's third category is degree of citizen power $^{6}$ which consists of three types, _partnership', _delegated power', and citizen

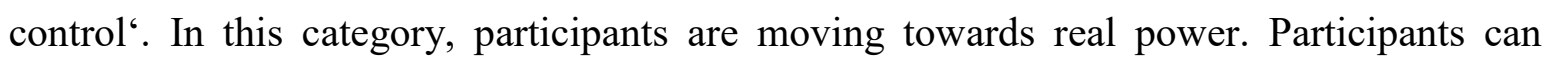
negotiate power with the power holders, and they have the right to make decisions for their own development.

Figure 10: Ladder of Citizen Participation

\begin{tabular}{c|c|}
8 & Citizen Control \\
\hline 7 & Delegated Power \\
\hline 6 & Partnership \\
\hline 5 & Placation \\
\hline 4 & Consultation \\
\hline 3 & Informing \\
\hline 2 & Therapy \\
\hline 1 & Manipulation
\end{tabular}$\quad$\begin{tabular}{l} 
Degrees of \\
citizen power \\
\hline
\end{tabular}

Arnstein, 1969, p217

Similarly, Pretty developed a typology of community participation with seven types of participation: from weaker to stronger in terms of power and influence; passive participation, participation in information giving, participation by consultation, participation for material incentives, functional participation, interactive participation, and self-mobilization (Pretty et al., 1995). Despite somewhat different terms being employed, the two typologies are very similar. Both focus on power distribution among participants within all types of participation. Community participation implies power in the sense that people can gain power when they gather together but power will dissipate when they separate (Arnstein, 1969). 
These two typologies are used to understand the meanings of community participation in various contexts such as rural development and community development. From these typologies, Bray (2001) contextualized the framework, =degrees of community participation', for the education context and this framework has been applied in many developing countries (Bray, 2001 see Section 3.5.2).

\subsection{Education in Development}

Education is said to be pivotal for development (Sachs, 2015). Development as mentioned above focuses on human development, meaning that humans are the object for development programs rather than economic growth for its own sake (Katie, 2005). According to the Human Development Index (HDI), education is one of key criteria for measuring human development (Kates, 2005). The HDI has three main categories to measure human development, namely life expectancy at birth, educational attainment, and standard of living (2005). In addition, education is one of the main sectors that global leaders believe will contribute to poverty eradication as indicated in the Millennium Development Goals (MDGs) (UN, 2015) ${ }^{11}$.

In the global development agenda 2015-2030, education continues to be pivotal for achieving sustainable development goals (Sachs, 2015). According to Sachs, regarding education, the SDGs have been set up to continue working on the remaining unachieved indicators and to minimize inequality of education attainment among children to result in development achievement (2015). To achieve the development goal, global leaders called on public and private sectors, international and local partners and local people to participate in development program implementation (UNESCO, 2013b).

\subsection{Participation in Education}

A number of education researchers argue that the participation of communities in education enhances children's performance at school, and is the motivating factor for children to continue through to tertiary education (Epstein, 2006; Griffin \& Steen, 2010; Sheldon, 2003; Shanders, 2001; UNESCO, 2013a, 2013b). These educational researchers agree that

${ }^{11}$ MDG 2: Achieve Universal Primary Education. All children have equal rights for free primary education. http://www.un.org/millenniumgoals/ 
community participation in education is the processes through which children, parents, community people, local authorities, teachers, the private sector, and other relevant stakeholders participate in school programs or in education related institutions.

Research shows that academic performance among children from different backgrounds varies (Griffin \& Steen, 2010). Children whose parents get involved in their learning generally receive better academic results than other students. This variation is argued to be partially caused by the disconnection between teachers, parents and community (Griffin \& Steen, 2010). Some communities may be very individualistic and this may cause the isolation within the community where children live, and not inspire collective action for supporting children. The participation of parents and communities in education is argued to bring substantial benefits for improving education (Epstein, 2006; Klein \& Ballantine, 1999; Sheldon, 2003; Shanders, 2001; Griffin \& Steen, 2010; Bryan \& Henry, 2012; Rose, 2003). These studies contend that the involvement of families and communities with schools, especially when they work together, increases the academic success of children.

To enhance participation and to promote collaborative work between schools, communities and families for children's learning, Joyce L. Epstein, who is a well-known education consultant, developed a school-family-community partnership framework for schools and education institutions (Epstein, 2006). This framework has been applied by several educational institutions and researchers in both developing and developed countries (Epstein, 2006; Klein \& Ballantine, 1999; Pang et al., 2004; Sheldon, 2003; Shanders, 2001; Griffin \& Steen, 2010; Bryan \& Henry, 2012; Rose, 2003). The following section provides the reviews of Epstein's participation framework which is useful in analyzing the different processes and forms that community participation can take.

\subsubsection{Forms of Participation: Epstein's Framework}

Epstein strongly believed that children can do better in their learning when teachers, families and the community work together to achieve learning and development goals of children (Epstein, 2006). To contribute to this contention, she suggests that educational institutions build strong partnerships. She suggests that: 
The strong partnerships are team based, with teachers, parents, and administrators working together to plan and implement goal-oriented programs, policies, and whole-school activities to create a sense of community between families and school (Epstein, 2006, p40).

To enhance strong partnerships, Epstein developed an involvement framework with six types of involvement (see Table 2). Epstein used the term _involvement ${ }^{6}$ to refer to various forms of participation but did not analyse them as being strong or weak (as in Arnstein's ladder of citizen participation). Thus, Epstein's framework is not judgmental because the concept of participation may change in accordance to the context, types of involvement and commitment of the implementers. This framework, as suggested by the author, is applicable in all levels of education, and in different contexts. In addition to Epstein's six types of participation, Griffin and Steen recommended Leading (2010) as an additional category for promoting partnership. Griffin and Steen recommend that in order to get communities and families to participate in education, leadership by school administrators and community leaders is required.

Table 2: Epstein's Framework for Forms of Participation

\begin{tabular}{|l|l|}
\hline \multicolumn{1}{|c|}{$\begin{array}{c}\text { Types of } \\
\text { involvement }\end{array}$} & \multicolumn{1}{c|}{ Description } \\
\hline Parenting & $\begin{array}{l}\text { The schools assist community and parents with parenting and childrearing } \\
\text { skills, in understanding child development, and in setting home conditions } \\
\text { that support children as students at each age and grade level. }\end{array}$ \\
\hline Communicating & $\begin{array}{l}\text { The schools keep community and families up-to-date on school programs and } \\
\text { student progress through effective school-to-home and home-to-school } \\
\text { communications. }\end{array}$ \\
\hline Volunteering & $\begin{array}{l}\text { Activities that support children and school programs, improve outreach, } \\
\text { training, and schedule to involve families as volunteers and improve family } \\
\text { attendance at events at school and in other locations. }\end{array}$ \\
\hline Learning at home & $\begin{array}{l}\text { The schools offer suggestions and techniques to involve families in learning } \\
\text { activities with their children at home. }\end{array}$ \\
\hline Decision making & $\begin{array}{l}\text { Include families as participants in school decisions, governance, and } \\
\text { advocacy through PTA/PTO, school councils, committees, and other parent } \\
\text { organizations. }\end{array}$ \\
\hline $\begin{array}{l}\text { Collaborating with } \\
\text { the community }\end{array}$ & $\begin{array}{l}\text { Coordinate resources and services for families, children, and the school with } \\
\text { businesses, agencies, and other groups. Provide services to the community. }\end{array}$ \\
\hline
\end{tabular}

Source: Epstein, 2006 
The aim of this framework is to provide guidance to school staff, families and communities to perform their partnership roles to ensure better academic achievement of their children. The concept of such partnerships is to build connections between schools, families, and communities so that the three partners assist each other in supporting children to have successful study outcomes in their future lives (Epstein, 1995).

The first type of participation is parenting. In Epstein's framework, parenting requires more awareness and understanding about the stages of child development (Epstein, 2006), so that parents, guardians or caretakers better understand the needs of children to develop mentally and physically (Bornstein, 2005). It is assumed that when parents are aware of child development, they provide better support to their children's learning both at school and at home, for example, parents motivate children to study at home, and bring children to school. The partnership works both ways with schools also assisting families in parenting and child rearing skills (Epstein, 2006; Griffin and Steen, 2010).

The second type of participation is communicating. This is crucial for school and parents to keep up-to-date information between home and schools. Effective communication allows teachers and parents to build common understandings about each other's needs and the encountered challenges in teaching and learning of teachers and children (Epstein, 1996; Griffin \& Steen, 2010). This shows children that school, communities and schools work together for them. Communication between school, families and community is the most effective way to link the home and school (Marockie and Jones, 1987). The school may receive constructive feedback from communities and parents with regard to school management, school environment, and quality of teaching and learning. In addition, the school can give updated information about school events to the parents, communities and local authorities. This type of involvement includes the culture of sharing information because parents often have little idea about their children's behavior at school. This communication enables teachers and parents to identify needs for supporting children's development. Schools play a dominant role in improving communication.

Conversely, poor communication is a barrier for parents to get involved in their child's education, and it can prevent children from achieving academic success (Griffin \& Steen, 2010). To improve the communication between teachers and parents, it is suggested that 
parents should be invited to participate in school planning, and any discussion which concerns children's learning and other education related issues (Griffin \& Steen, 2010).

The third form of participation is volunteering. This is the volunteer work of parents and the community at school events. The framework suggests that school programs should include or invite parents to join in training, outreach activities and increase family attendance in any events in the school (Epstein, 2006). This may build a connection between the school and family and familiarize families with school. Getting communities and parents to volunteer in the school program is not easy; it needs intensive effort on the part of school administrators (Griffin \& Steen, 2010). Griffin \& Steen have suggested the creation of a school program which enables parents and communities to volunteer to provide skills that relate to children's learning (2010).

The fourth type of participation is learning at home. Families may help children through checking homework, playing, and storytelling. The school program may provide assistance in terms of suggesting techniques and offering advice to parents to support children's learning at home. Research shows that the engagement of families in children's learning at home enhances children's performance at school (Klein \& Ballantine, 1999). Griffin \& Steen (2010) found that parents who themselves have a higher level of formal education are more involved in their children's learning at home than those who have a low level of formal education. Therefore, it is suggested that schools and school administrators coordinate training or workshops for parents that could enhance their understanding of the learning needs of children to assist their children learning at home (Griffin \& Steen, 2010). As an example, Epstein suggests developing a homework monitoring system for parents to help their children's learning.

The fifth type of participation is the inclusion of families in decision making. The framework suggests that families be included in any decision making which affects the common interests of children and the community. Communities and parents should be invited to join meetings, advocacy activities, school committees, and be involved in school governance. Involving families in school decision making is argued to be a main goal of school based management and school reform efforts (Epstein, 2006) because it enhances not only shared roles and responsibilities among partners, but also mobilizes talent and 
specific skills from parents and communities in accelerating the academic success of children (Griffin \& Steen, 2010). Parents and communities may also feel empowered which results in ownership within the community. However, to have meaningful participation, efforts must be made to ensure that the families of vulnerable children are included so that their voices are heard (Griffin \& Steen, 2010). The involvement of PTAs in school decision making processes is an example of type five involvement.

Sixth, collaborating with the community is perceived to be both effective and efficient. The school provides education services to families" children in the community; communities and parents mobilize resources and related skills to help the school (Epstein, 2006). This may enable learning processes and links theoretical learning from the classroom with the real world in the community wherein children live. For example, children improve their numeracy, literacy skills and social interaction through the collaboration of school, community and their parents. Each partner has a complementary role to another. Thus, according to DeFilippis and Susan (2008), it is not only parents and people directly in the education community who should get involved in this collaboration, but also relevant institutions such as business people, religious organizations, community clubs, youth clubs, and local investors within the school community.

Griffin and Steen (2010) found that Epstein's participation framework would not be effective unless leadership roles are applied by the educational administrators. The task of leading involved the facilitation, coordination, designing, implementing, monitoring and evaluation of the education or schooling program. Griffin \& Steen (2010) stressed that leading roles should be the responsibility of the educational institution leaders or/and school.

Research in Cambodia, has also found that the participation of families and community in education can increase the attendance of children in class and reduce trouble in schools (Pellini, 2010). Absenteeism is one of the common problems that occurs in Cambodian schools. The possible causes are children's slow learning, truancy and children's personal health problems, especially with girls (Pellini, 2010). Pellini suggests that parents can help in solving these problems, and that as a result of their involvement children are more likely to graduate from high school and attend college (2010). 
Despite its usefulness, Epstein's framework does not seem to address the levels of participation that describe power dynamics. Thus, while I will use Epstein's framework as a roadmap to investigate the forms and process of community participation in remote schools in Cambodia, I will complement it with Bray‘s framework (see Table 3) for analyzing different _degrees of community participation'. Bray's participation framework has been used in education in Asia and is particularly applicable for the Cambodian context.

\subsubsection{Levels of Community Participation in Education: Bray`s framework}

Mark Bray (2001) brought together the Arnstein's typologies about levels of participation with observed practices in education (Table 3). It should be noted that Bray's _practices` do not map exactly onto Epstein's forms of participation. Therefore, in Table 4, I merge the frameworks of Bray and Epstein to provide a comprehensive framework for my analysis in Cambodia.

Table 3: Degrees of Community Participation in Education

\begin{tabular}{|c|c|c|c|c|c|c|c|}
\hline \multicolumn{7}{|c|}{$\begin{array}{l}\text { Pseudo } \\
\text { Participation }\end{array}$} & $\begin{array}{l}\text { Genuine } \\
\text { Participation }\end{array}$ \\
\hline $\begin{array}{l}\text { Community } \\
\text { Role/Educati } \\
\text { on functions }\end{array}$ & $\begin{array}{l}\text { Use of } \\
\text { service } \\
\text { (1) }\end{array}$ & $\begin{array}{l}\text { Contribution } \\
\text { of resources } \\
\text { (2) }\end{array}$ & $\begin{array}{c}\text { Attendance } \\
\text { at meetings } \\
\text { (3) }\end{array}$ & $\begin{array}{l}\text { Consultation } \\
\text { on issues } \\
\text { (4) }\end{array}$ & $\begin{array}{l}\text { Involvement } \\
\text { in delivery } \\
\text { (5) }\end{array}$ & $\begin{array}{c}\text { Delegated } \\
\text { powers } \\
\text { (6) }\end{array}$ & $\begin{array}{c}\text { Real } \\
\text { powers (7) }\end{array}$ \\
\hline Planning & & & & & & & \\
\hline $\begin{array}{l}\text { Mobilizing } \\
\text { resource }\end{array}$ & & & & & & & \\
\hline $\begin{array}{l}\text { Monitoring } \\
\text { the schools }\end{array}$ & & & & & & & \\
\hline $\begin{array}{l}\text { Teacher } \\
\text { training }\end{array}$ & & & & & & & \\
\hline $\begin{array}{l}\text { Textbook } \\
\text { design }\end{array}$ & & & & & & & \\
\hline $\begin{array}{l}\text { Textbook } \\
\text { distribution }\end{array}$ & & & & & & & \\
\hline Certification & & & & & & & \\
\hline $\begin{array}{l}\text { Building and } \\
\text { maintenance }\end{array}$ & & & & & & & \\
\hline $\begin{array}{l}\text { Monitoring } \\
\text { the schools }\end{array}$ & & & & & & & \\
\hline $\begin{array}{l}\text { Teacher } \\
\text { training }\end{array}$ & & & & & & & \\
\hline $\begin{array}{l}\text { Textbook } \\
\text { design }\end{array}$ & & & & & & & \\
\hline
\end{tabular}

Source: Bray, 2001 modified by Author 
According to Bray (2001) participation in education is placed between two extremes: genuine participation' and _pseudo-participation'. Genuine participation is the process in which participants voluntarily participate in development process. They have equal rights, power and influences in making decision. In contrast, in pseudo-participation, people participate for consultation and information giving in development, research or in completing surveys. Participants do not have the power or rights to make decisions. Between pseudo-participation and genuine participation, certain types of participation are identified including (1) use of service, (2) resource contribution, (3) attending meeting, (4) consultation, (5) involvement in service delivery, (6) delegated power and (7) real power.

As shown in Table 3, Bray lists_practices ' of community participation in education that indicate the participation at all levels from grass roots to national level. In the Cambodian context, however, communities tend not to have much influence in decision-making at higher levels such as policy design, curriculum development, or employing teachers. Furthermore, in the Cambodian context the community participation at the grassroots level is the focus of the national education strategy.

In order to contextualize the frameworks for participation in education to the Cambodian context, and to allow for a full discussion of various forms of participation, I have amalgamated the frameworks of Bray and Epstein (see Table 4 below). This matrix will be used to assess the forms of community participation in education.

Table 4: New Matrix Forms and Degrees of Participation in Education

\begin{tabular}{|c|c|c|c|c|c|c|}
\hline \multirow[b]{2}{*}{$\begin{array}{c}\text { Forms } \\
\text { Participation }\end{array}$} & \multicolumn{4}{|l|}{$\begin{array}{l}\text { Pseudo } \\
\text { Participation }\end{array}$} & \multicolumn{2}{|c|}{$\begin{array}{r}\text { Genuine } \\
\text { Participation }\end{array}$} \\
\hline & $\begin{array}{cc}\text { Use of } & \text { Resources } \\
\text { service } & \text { Contribution } \\
(1) & (2)\end{array}$ & $\begin{array}{l}\text { Attending } \\
\text { meetings } \\
\text { (3) }\end{array}$ & $\begin{array}{c}\text { Consultation } \\
\text { (4) }\end{array}$ & $\begin{array}{l}\text { Involvement } \\
\text { in delivery } \\
\text { (5) }\end{array}$ & $\begin{array}{l}\text { Delegated } \\
\text { powers } \\
(6)\end{array}$ & $\begin{array}{l}\text { Real } \\
\text { powers } \\
(7)\end{array}$ \\
\hline \multicolumn{7}{|l|}{$\begin{array}{l}\text { Parenting } \\
\text { activities }\end{array}$} \\
\hline \multicolumn{7}{|l|}{$\begin{array}{l}\text { Learning at } \\
\text { home }\end{array}$} \\
\hline \multicolumn{7}{|l|}{ Communicating } \\
\hline \multicolumn{7}{|l|}{ Volunteering } \\
\hline \multicolumn{7}{|l|}{$\begin{array}{l}\text { Decision- } \\
\text { making }\end{array}$} \\
\hline $\begin{array}{l}\text { Collaborating } \\
\text { with the } \\
\text { community }\end{array}$ & & & & & & \\
\hline
\end{tabular}

Source: Compiled by the Author, based on Epstein, 2006 and Bray, 2000 


\subsection{Mobilization of Community Resources}

Community mobilization is one of the characteristics of community participation in education (Rose, 2003). According to Rose, community mobilization occurs when the government faces a budget deficiency to support education programmes (Rose, 2003). Communities and parents are called on to contribute their available resources for school development and maintenance and education development.

Similarly, in the Cambodian context, Save the Children Cambodia (2015), Clayton (2005), Pellini $(2005,2007)$ and Bray (2001) have remarked that as a form of community participation, community contributions commonly take place in education to fill the financial deficiency in the schools. Communities contribute their available resources such as money, construction materials, labour and/or at least ideas for school development (Pellini, 2007). The resource mobilization is reported by the school committee such as Parent-Teachers Associations (PTA) or School Support Committee (SSC) (Dykstra \& Kucita, 1997). The committee assists the schools in mobilizing local people to participate in school construction through contributions such as money, materials and labour. Cambodian society is socially hierarchical - better-off people, village leaders, Buddhist monks and clergy people who maybe members of SSCs are highly respected - and they are very effective in mobilizing resources for school development (Pellini, 2005).

\subsection{Recent Research in Community Participation in Education}

In the last few years, there have been a number of studies conducted on community participation in education in different locations in Cambodia ${ }^{12}$. Recently, for example, Save the Children (2015) conducted a study on a programme called Based Budget Reform and Community Participation in Primary Education in Cambodia. Nguoun, (2012) conducted a study on parental participation in education, and Pak (2012) studied school-familycommunity partnership. These studies focused on the participation of particular community groups in education in Cambodia, whereas this study focuses holistically on all community

\footnotetext{
${ }^{12}$ The studies on community participation in education include Pak (2012), Nguon (2012), Save the Children Cambodia (2013, 2014, and 2015), UNDP (2013) and World Bank (2013).
} 
stakeholders involved in education in rural Cambodia. As such, this study forms a valuable complement to previous research.

Although Save the Children Cambodia conducted studies with a similar brief to my own, their studies have been largely carried out with government officials, teachers and relevant NGOs, and did not involve parents and community members. The purposes of their studies were to assess the progress and challenges of community participation in primary education by using qualitative methodology. According to them community participation was categorized into two types: direct and indirect participation. First, communities (especially parents) participated through attending annual open ceremonies, signing monthly student study records, contributing resources for school development and giving their children private tutoring. Second, communities participated directly in education through SSCs who are their representatives. SSCs participated in collecting and encouraging children to go to school, mobilizing community resources, helping in school infrastructure development and ensuring children safety in the schools and community. Their studies also found some challenges of participation, such as the SSC having low management and financial capacity which hindered them in decisions about school budget management. There was also less transparency in sharing information about budget plans, slow responses of the government to solve the problems concerning poor quality teaching and less functionality of the SSC in some roles.

Even if their studies identified the processes and challenges of community participation in education, the study did not include the perspectives of parents and community members. Nor did it explore other types of participation such as communicating, parenting, learning at home, volunteering and collaborating. In addition, this type of study tends to be focussed on the ways that community groups participate rather than the two-way relationship between schools and communities which this study aims for.

Another recent large-scale study was conducted by Nguon (2012) to determine parental participation in children's learning in secondary school in Cambodia. However, the study did not cover the involvement of community people in the investigation. It focussed only on the parental involvement. The study found three types of parental participation: parental contributions to schools; school-based participation and home-based participation. Parental 
contribution concerned the contribution of money, materials and labour to respond to the request of the schools. School-based participation was the engagement of parents in the school events, meetings and consultation with the schools. Home-based participation was the involvement of parents in sending children to schools, checking children's homework, talking with children about their learning progress, ensuring children having the appropriate learning environment and constantly encouraging children to study.

A further study conducted by Pak (2012) was on community participation in education. He focused only on the channels of communication used by community and education stakeholder to communicate about children's learning. Pak found that the practices of partnerships among schools, families and communities community had not met the outcomes of community participation in the Child Friendly School policy. He suggested further research on the other forms of community and parental involvement in children's learning. This study, to some extent, is responding to this suggestion in exploring the additional forms of community participation in education.

\subsection{Conclusion}

Community participation in community development is the inclusive process of local people being involved in decision making, starting from identifying local problems to planning, implementation, monitoring and evaluation. In the education context, community participation is the involvement of community members and parents supporting children's learning at schools and in the community. Community members and parents may participate in education in several forms which can be categorized into six main types (Epstein, 2006), and the power and influence of participants varies depending on how they participate: pseudo-participation or genuine participation (Bray, 2001).

A number of studies reported that community participation in education provides substantial benefits to children's learning. There are several studies conducted in this topic in different contexts. In the Cambodian context, several studies have been conducted in education in the last ten years such as Bray (2001), Pellini (2007), Clayton (2005), Dy (2004) and Collins (2009). However, there are few recent studies conducted in community participation in education Cambodia (Nguon, 2012; Save the Children, 2015; Pak, 2012). 
Even if these studies found various forms of community participation in education, some types of participation which should be investigated were not explored. These include asking what the other forms of community participation are that may be occurring in rural Cambodian primary schools.

Hence, my study is conducted to complement the literature above in contributing to the body of knowledge on community participation in education in Cambodia. To fill the gap in the literature, my study aims to explore the forms and processes of community participation in education, degrees of community participation in education and methods of community mobilization. The study merges Epstein's participation framework and Bray's framework to explore multi-dimensional participation from families, communities and the schools. The method of data collection to create this knowledge will be described in the next chapter. 


\section{CHAPTER 4}

\section{RESEARCH METHODOLOGY}

\subsection{Introduction}

This chapter discusses the methodology that was designed for finding answers to the research question. In this chapter, the methods, approaches, tools and techniques used in this research are explained. The chapter starts by discussing the epistemological worldview underlying the research. The details of the research design are then given, followed by the research procedure and data collection methods. The methods of data analysis are described before a discussion about the limitations of the research. Ethical considerations and researcher positionality will be discussed in the latter section of the chapter. Considerations of the validity and reliability of the research are highlighted before the conclusion of the chapter is made.

\subsection{Epistemological Approach}

The aim of this study was to investigate community participation in local education in Cambodia with specific objectives: to investigate the forms and processes of community participation in education; to explore the community mobilization methods used by schools; and to investigate the degree of community participation in the local education.

There are different ways of understanding the world. The positivist view is more objective and contends that the material world has its own meaning independent of human interpretation (Becker \& Niehaves, 2007). In contrast, constructivism holds that the meaning of the material world depends on human interpretation. The interpretivist approach (Della Porta \& Keating, 2008) combines these two epistemologies in that it involves the interpretation of objective data along with, and in light of, the history, experience, culture and society of human beings.

The interpretive epistemological approach was used in my research because the research questions necessitated the interpretation of the meaning arising from the study of social phenomena. According to the characteristics of the research described in the introductory 
chapter, the objectives of this research are exploratory rather than confirmatory (Tashakkor \& Teddlie, 2003).

Interpretivism contends that the different ways in which the world is viewed arise from the influence of our beliefs and value systems (Walliman, 2011). This approach is used because it allowed me to acknowledge and interpret the community perspectives and understandings. The interpretation was carried out in a way that celebrates and supports different values, beliefs and cultures of the community, as discussed below. This is particularly important because historically (as shown in the literature review), research initially prepared for and focused on Western situations has been applied to Cambodia without a deep understanding of cultural differences. In addition, the interpretive stance accommodates my recognition of the way in which my analysis and interpretation has been influenced by my experience, knowledge, background and culture as an indigenous Cambodian.

\subsection{Research Design}

\subsubsection{Research Objectives}

Research Objective: To investigate community participation in education in the remote primary schools in Samlot district in Cambodia

\section{Specific Objectives:}

To determine the forms of community participation in education in the remote primary schools in Samlot district in Cambodia

To determine the processes of community participation in education in the remote primary schools in Samlot district in Cambodia

To find out community mobilization methods different schools used to mobilize community members to participate in education

To assess the degrees of community participation in the remote primary schools in Samlot district in Cambodia 


\subsubsection{Research Methods}

I used a case study approach to examine community participation in education. I intended to investigate the parameters of community participation in certain rural schools that had been the target of government efforts and the interventions of non-governmental organizations (NGOs) in mobilizing communities to participate in education. According to Chapters 2 and 3, community participation in education has already existed to a certain extent within schools throughout the country. This means that the dynamic of community involvement in education has been evolving differently in different places. Levels of community participation are sometimes dependent on the external interventions of governmental organizations and non-governmental organizations (Bray, 2001; Arnstein, 1969; Pretty et al., 1996).

To examine the participation of communities in education, I chose to use the case study approach to focus on four primary schools in the Samlot district of Battambang province, Cambodia. Yin (1994) has suggested that case study research is appropriate for examining organizations, individuals, communities, past events or ongoing events. More explicitly, as quoted in Della Porta and Keating (2008, p 225), Charles Ragin suggests that:

A case study is a research strategy based on in-depth empirical investigation of one, or a small number, of phenomena in order to explore the configuration of each case, and to elucidate features of a larger class of (similar) phenomena by developing and evaluating theoretical explanations (Ragin, 2000, p64-68 cited in Della Porta \& Keating, 2008, p 225).

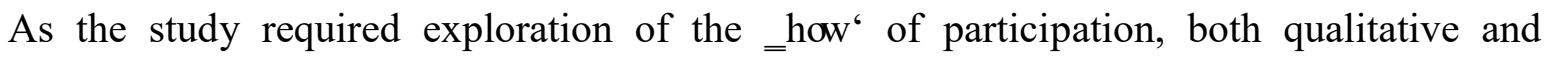
quantitative methods were chosen as appropriate for collecting and analyzing data. Qualitative research is an approach for exploring and understanding perspectives and interpretation of the individuals about the social contexts (Denscombe, 2010; Rubin \& Rubin, 2011). Qualitative data collection methods were used to collect data from local people in the field by using different tools such as interviews, group discussions, document review, and observation (Creswell, 2013). 
To triangulate the qualitative data, a quantitative method of a survey was used with parents and community members in selected school communities. This quantitative data collection tool was used to complement the qualitative data (Tashakkor \& Teddlie, 2003). Thus, this case study employed mixed methods. Even though mixed methods have been criticized as being weak for generalization (Yin, 199), I found these methods to be more insightful than

a single method (qualitative or quantitative) as they were better able to test inferences and seemed more robust (Tashakkor \& Teddlie, 2003).

\subsubsection{Research Location}

This case study was conducted in Samlot, a very isolated district of Cambodia (as described in the context chapter). The district is in some respects quite different to other districts. It is geographically isolated with bad road conditions. It has shown a marked improvement in education since early 1990s in terms of community participation and the enrolment rate for boys and girls (MoEYS, 2015a). It has received significant interventions from NGOs resulting in improvements in education in recent decades. It is for these reasons that I selected the district for the case study, particularly in order to determine their best practices.

Four primary schools were selected as individual cases for the study. For each school, the same numbers of participants were sought and they were asked the same sets of questions. The primary schools selected were Aphiwat Samlot and Dauntret, which are in Tasanh commune; and Sung 1 and Sre Reach which are in Sung commune.

There were four major reasons for selecting these four schools were as follows:

- The four schools have different physical layouts. These different layouts would allow me to analyze different forms of community participation and the methods of community mobilization. Two schools, Aphiwat and Sung 1 are on the main road (with people living along the road), and the other two, Dauntret and Sre Reach are off the main road (where the houses are sparsely located throughout the villages).

- The four schools, as suggested by Ministry of Education, Youth and Sport (MoEYS), have recorded levels of community participation which could be studied (personal communication with District office of Education officer). The 
involvement of local people in a school was established as already taking place in the area.

- The proximity of the schools to both the District Office of Education (DoE) and to the main road was considered. Schools that are close in proximity to the DoE and on the main road (Aphiwat) tend to receive more attention from the education authority and the public while the other schools do not. This difference, I hoped, would allow me to analyze different patterns of participation in the communities.

- Two schools in Sung commune are in an old village with a long history of continued residence. People within these two school communities were local people who have lived there for many years before the 1990s. The other two schools communities have a mixed population (newcomers and more established residents). The mixture of the population in these communities creates a diversity of personal education levels and aspirations and family cultures.

\subsubsection{Research Participants}

The selection of research participants was carefully made after consultation with my research supervisor, and in light of research literature and discussions with my peers. Eighty-one participants were selected to join in the study, including school directors, teachers, School Support Committee (SSC) leaders, parents, religious leader, local authorities, non-governmental organizations (NGOs) staff, a District office of Education (DoE) officer, and other relevant educational stakeholders. These participants were selected because they offered a diverse range of perspectives on the research questions and had different experiences of collaboration.

Four school directors were purposefully selected for the study as I was hopeful that they would share with me their thoughts about the community and education in their school. These four informants were interviewed to get answers for the research questions. Four SSC leaders from the four schools were selected for in-depth interviews to get information about their participation in education and the support that they had in mobilizing community participation. These interviews also helped me to verify the data from the interviews with school directors. Four teachers were selected for interviews to determine the participation of parents in their children's learning and the relationship between parents 
and schools. At the same time, local authorities such as one village leader and two commune council members were interviewed to explore their participation in education. To investigate the participation from NGOs, three staff from two NGOs were invited for interviews.

To obtain the parents' perspectives, a questionnaire survey and Focus Group Discussions (FGDs) with parents were conducted. Forty family members were selected for the questionnaire survey. This survey explored aspects of the parental participation in education. It was also hoped that this data would help to verify the information from the interviews with school directors, teachers, SSC leaders and local authorities. In addition, twenty-one parents were selected for focus group discussions. The discussions were on the parental participation in their children's learning, parental contributions to education and the challenges in participation in education. These discussions were important because all participants could be involved in the conversation about the same topics within the groups.

Table 5: List of Participants by Schools

\begin{tabular}{|l|c|c|c|c|c|}
\hline $\begin{array}{c}\text { Research } \\
\text { Participants }\end{array}$ & $\begin{array}{c}\text { Aphiwat } \\
\text { Samlot }\end{array}$ & Dauntret & Sung 1 & Sre Reach & $\begin{array}{c}\text { Methods of data } \\
\text { collection }\end{array}$ \\
\hline School director & $1(\mathrm{M})$ & $1(\mathrm{M})$ & $1(\mathrm{M})$ & $1(\mathrm{M})$ & KII \\
\hline Teacher & $1(\mathrm{~F})$ & $1(\mathrm{M})$ & $1(\mathrm{~F})$ & $1(\mathrm{M})$ & KII \\
\hline SSC leader & $1(\mathrm{M})$ & $1(\mathrm{~F})$ & $1(\mathrm{M})$ & $1(\mathrm{M})$ & KII \\
\hline Parents & $10(\mathrm{~F}=8)$ & 0 & $5(\mathrm{~F})$ & $6(\mathrm{~F})$ & FGD \\
\hline Monk leader & $1(\mathrm{M})$ & 0 & 0 & 0 & KII \\
\hline Village leader & $1(\mathrm{M})$ & 0 & 0 & 0 & KII \\
\hline
\end{tabular}

Table 6: List of Participants by Community/Institutions

\begin{tabular}{|l|l|l|c|}
\hline \multicolumn{1}{|c|}{ Institutions } & \multicolumn{1}{|c|}{ Participants } & \multicolumn{1}{c|}{ Sex } & Method used \\
\hline Tasanh commune & Commune Council member & $1(\mathrm{M})$ & KII \\
\hline Sung commune & Commune leader & $1(\mathrm{M})$ & KII \\
\hline Samlot DoE & Deputy director & $1(\mathrm{M})$ & KII \\
\hline $\begin{array}{l}\text { World Vision } \\
\text { Cambodia (WVC) }\end{array}$ & $\begin{array}{l}\text { Education Project coordinator/World } \\
\text { Vision Cambodia }\end{array}$ & $1(\mathrm{M})$ & KII \\
\cline { 2 - 4 } $\begin{array}{l}\text { Khmer Education } \\
\text { Network (KHEN) }\end{array}$ & $\begin{array}{l}\text { Development Transformational } \\
\text { Facilitator/WVC }\end{array}$ & $1(\mathrm{~F})$ & KII \\
\cline { 2 - 4 } $\begin{array}{l}\text { Tasanh \& Sung } \\
\text { commune }\end{array}$ & Project Coordinator/KHEN & $1(\mathrm{M})$ & KII \\
\hline
\end{tabular}

KII: Key Informant Interview 


\subsubsection{Timeframe of the Research}

The research took one year to complete, starting in March, 2015 and finishing in February, 2016. However, data collection in Cambodia took only eight weeks from the third week of April to the second week of June.

\subsection{Research Procedure}

I divided my research process into four stages: planning, fieldwork, analysis and writing. In the planning stage, I discussed the value of my research topic and the possibility of the research with academics. I also discussed my ideas with development practitioners from NGOs in Cambodia who were working in the proposed research area (this included a telephone call with WVC staff). I also sought feedback from former colleagues who were working in development NGOs in Cambodia (phone calls with WVC staff), postgraduate classmates (personal communication) and local people in Cambodia such as school directors and the deputy District Office of Education of Samlot District through phone calls. The consultation with these people concerned the aspects of community participation in education in the proposed research area, and the specific schools that I should select for the case studies. In addition, I consulted the literature in both development and education to further refine my research question.

From these discussions and from my preliminary review of the literature, I developed a research proposal and, after acceptance, I gained approval from the Victoria University of Wellington Human Ethics Committee (VUWHEC) to carry out the fieldwork in Cambodia (see Appendix 4). During my first two weeks in the field, I wrote to government officials and organizations that I wanted to interview (see Appendix 10,11, 12). Cambodia has a culture that can be considered hierarchical and bureaucratic, and people can be very politically sensitive towards issues, especially when working within the government sector (Pellini, 2007). For this reason I wrote formal letters to district authorities, community councils, DoE, as well as emails to WVC operational managers and the Khmer Education Network (KHEN) country director. I could not undertake data collection unless I got permission from these organizations (by e-mail). 
Once I had the necessary permissions, I began the data collection in the third week of my field work and continued for six more weeks. I transcribed the interviews on the same day as they took place as it was easier for me to recall and decipher my field notes and to relisten to the audio tape. Daily reflection and a journal were important tools for the research which were used to complement the interviews.

The analysis and writing stages included further revision of the literature and analysis of secondary data collected from the internet both whilst in Cambodia and when back in New Zealand. The methods of data analysis will be mentioned in Section 4.6.

\subsection{Data Collection Methods}

As mentioned in the section above, this case study used mixed methods. It involved multiple forms of data collection ranging from document analysis, interviews, focus group discussions, observation and a questionnaire survey.

\subsubsection{Document Analysis}

The first form of data collection was document analysis. I collected formal and informal documents which were relevant and available for my case study. Formal documents were documents that were compiled and analyzed by an organization for specific purposes and they were formalized by the organization through an organization stamp; for instance, a school development plan, new academic year report, mid-term academic report, annual academic reports and school regulations. Informal documents were those in the forms of charts, tables, organizational structure and hand written journals ${ }^{13}$.

Data from the webpage of the Ministry of Education, Youth and Sport (MoEYS) gave me important background information about the education system, statistics, school conditions, and management systems in the area, as well as the situation of community participation in education. From this source, I could also retrieve information about rates of enrolment, student dropouts, and transition rates.

\footnotetext{
${ }^{13}$ Schools in general have tables of statistics, organization structures and lists of volunteer groups and so on that hang on the walls.
} 
In Samlot district itself, I collected statistics about the schools and their students from the District Office of Education (DoE). The education reports at the district level were also collected from DoE officers. The documents from the DoE provided educational statistics at the district level and this enabled a comparison among schools.

At the individual school level I collected school development plans, school annual reports, minutes of meetings, SSC structure, Student Councils (SC) structure, school maps, statistical tables and charts, and activity photos displayed in the school office. The school development plans showed the inclusion of community people in the planning process. For instance, the school planning manuals included community roles in school development. These documents provided information about the level and extent of participation by the community in local education. I asked for permission from the document owners to take photos of these documents for research purposes.

\subsubsection{Key Informant Interviews}

Interviews were a key method to explore the social phenomenon of community participation in schools. The interviews gave me the chance to build relationships with the interviewees and allowed me gain some understanding of the lives of the research participants (Kayrooz \& Trevitt, 2004). To explore the various aspects of this issue in each school's wider community, I conducted interviews with a number of key informants. Key informants were people who could provide extensive and detailed information about the activities or organizations.

Key Informant Interviews (KII) started with school directors to explore community participation in education from their perspective. The primary questions for school directors were about the forms and processes of community participation in education and the methods of community participation that the schools used. These interviews gave me information about community participation from the perspective of the school directors and helped me to identify other educational stakeholders. I then sought interviews with different stakeholders for balance and to gather a diversity of opinions.

Although I interviewed school directors about the participation of SSC in education, I needed to conduct interviews with SSC leaders themselves (as representatives of families 
and communities in schools) to gain a deeper understanding of their experience with education and schools. The interviews with SSC leaders were focused on the process of the involvement of SSCs in education. In general, I found that the information gained from the SSC leaders was consistent with that of the school directors, helping me to feel confident in the validity of my research findings.

Interviews with local authorities, teachers, monk leaders, and NGO staff were conducted afterwards. The questions in the interviews with teachers were focused on the relationships between teachers and parents in enabling children's education, and any barriers that affected this relationship. The interviews with local authorities focused on how they got involved in education and their roles in getting community people involved in education. Monk leaders from one school were interviewed about the involvement of religious institutions in education and the relationship between schools and pagoda. Three development workers from two NGOs were interviewed about the involvement of NGOs in education. These interviews explored how NGOs provide support to education and how NGOs facilitate community participation in education.

I started every interview by introducing the research topic and the purpose of the study. After that, consent forms were read for participants. The research participants were often reluctant to sign the consent forms as they thought they could have trouble with the signed consent forms with the authorities. This was a sensitive issue for them so we agreed to use verbal consent. It took time to build rapport with participants, and I felt that the most valuable information was gained at the end of interviews, when we were more relaxed.

\subsubsection{Focus Group Discussions (FGDs)}

Focus group interviews were used to collect qualitative data. They were useful in helping me to collect a substantial amount of information from a group of people at one time (Marshall \& Rossman, 2006) and to generate diverse ideas (Barbour, 2008; Kayrooz \& Trevitt, 2004). They also allowed me to get a feel for the impression of the participants of the topics and I was able to gain information from both the discussion and from my observations (Freeman, 2006; Stewart \& Shamdasani, 2014). Three different FGDs were conducted following the interviews with school directors and teachers with three groups of 
parents within different school communities. The information gained from these discussions contributed to enhancing the validity and reliability of the research.

The focuses of these discussions was the participation of parents in education at home and at school (see Table 7). Open-ended questions were used with probing questions. My facilitation role was important in those discussions. I started the discussion with a selfintroduction and then introduced the research topic. After obtaining their consent to be interviewed I raised a question about the topic and this started the discussions. During the discussion, I encouraged every participant to have a say. Some participants questioned each other about the topic. When this was occurring, I listened to their discussion and carefully noted their position in the argument within the discussions. At the end of the discussion, I always asked participants for any questions or concerns about my research. To record these discussions, I used note taking techniques, and I asked permissions from the participants to record their voices.

Table 7: Data Collection Tools

\begin{tabular}{|c|c|}
\hline Participants & Primary questions \\
\hline \multicolumn{2}{|l|}{$K I I$} \\
\hline Four School directors & $\begin{array}{l}\text { - How has community participation occurred in your community? } \\
\text { - Who are the education stakeholders? Who participates? } \\
\text { - What are the forms of participation? } \\
\text { - How has each form of participation taken place? } \\
\text { - How do you mobilize community participation in education? }\end{array}$ \\
\hline Four Teachers & $\begin{array}{l}\text { - What is the relationship like between teachers and parents? } \\
\text { - How do you communicate with parents and community members? }\end{array}$ \\
\hline Four SSC leaders & $\begin{array}{l}\text { - In what ways do you participate in education? } \\
\text { - Can you describe each form of participation? } \\
\text { - How do you help schools to mobilize community members to } \\
\text { participate in education? }\end{array}$ \\
\hline Three Local authorities & - How do you participate in education? \\
\hline Three NGOs staff & $\begin{array}{l}\text { - What roles do NGOs have in education? } \\
\text { - How do NGOs intervene in education? } \\
\text { - How do you help the school to get the community involved in } \\
\text { education? }\end{array}$ \\
\hline \multicolumn{2}{|l|}{ Focus Group Discussions } \\
\hline 26 Parents & $\begin{array}{l}\text { - How do you support your children's learning? } \\
\text { - How do you support the school? } \\
\text { - } \quad \text { Do you have any challenges participating in school? }\end{array}$ \\
\hline \multicolumn{2}{|l|}{ Small Survey } \\
\hline 40 Families & $\begin{array}{l}\text { - What are the forms of community participation in education? } \\
\text { - How do you participate in education? } \\
\text { - Are there any challenges to participation? }\end{array}$ \\
\hline
\end{tabular}




\subsubsection{Observation}

I use observation techniques to collect additional information during my field research. Observation enabled me to gather information that was not being told by the participants (Kayrooz \& Trevitt, 2004). I prepared observation checklists (what, where and when) that were divided into two main categories, physical observation and behavioral observation. These checklists were used during the field work (see Appendix 3).

\section{Physical observation}

In each school, certain areas were observed and noted such as the school environment, the infrastructure, office systems, and the school's organizational structure. These aspects were informative for the study. For example, most school facilities displayed names of community people who had made financial contributions in the construction of amenities such as toilets, wells, playgrounds, buildings, fences and so forth. Not only were the names written on these tangible facilities, but also the amount of money contributed. These features provided me with additional information about the forms of participation by the community in their local school.

Observation of the school offices was also informative. The structure of SSCs, Student Councils (SC), photos of community participation/activities in school were all displayed in the school offices. These visual materials indicated aspects of community and student participation in education. To store these documents, I used my smartphone to take photos or made copies of those documents.

\section{Behavioral Observation}

I managed my time to allow for observing the routine activities at each school. During my six weeks of data collection in Cambodia, I spent one day per school observing the routine activities. I got up early in the morning to observe morning activities in the schools. Observations focused on who was visiting the school from the community, children's activities and the interaction between community people and teachers. These observations helped me to categorize the observed activities into various themes. Observation was also 
used during the interviews and discussions because the behavior and attitude of the interviewees could add further nuances to the information.

\subsubsection{Questionnaire Survey}

Semi-structured interviews were used with parents to provide supplementary information to the focus group discussions and to check the validity of other information (Kayrooz \& Trevitt, 2004). A questionnaire-style survey was chosen as it takes a short time to complete. The survey was conducted with forty families from the four school communities and aimed to identify and assess general forms of participation that occurred among community people in this context. The information gained from this survey was used to triangulate the information received from interviews and discussions. The questions in this survey included the general forms of participation in education and school development, motivation factors and the challenges of participation (see Appendix 2).

\subsection{Data Analysis}

\subsubsection{Data Transcription}

I translated and transcribed the interviews right after the interviews. Because I interviewed in the Khmer language (my mother tongue), I had to translate the interview into English before transcribing. Undertaking this task immediately after the interviews enabled me to make use of my fresh memories of the interview as I listened to the audio tape. In addition to the transcripts, I typed the report from my journal into soft documents. In my journal, I describe my mood, behaviours of the participants and my personal reflection so that I could evaluate the accuracy of the information given during the interview.

\subsubsection{Data Analysis}

I used Epstein's participation framework to investigate and analyze the forms and processes of participation of the communities in education and the methods of community mobilization (Epstein, 2006), and Bray's degree of participation (Bray, 2001) to evaluate

the degrees of community participation in education in the research area. I used NVivo 10 for data analysis. Adapting Epstein's framework, six main themes were created that accurately reflected my research findings: parenting, communicating, volunteering, 
learning at home, collaborating and decision making. These were further analyzed using sub-themes of each type of participation. With Bray's framework, the degree of participation in education (from pseudo-participation to genuine participation) was used to determine the degree of participation of the communities in the remote primary schools in Cambodia.

Thus the analysis of the data collected from the fieldwork can be summarized as having three steps: deducting the data, classifying the data into types of participation, and evaluating each type of participation.

\subsection{Limitations of the Study}

This case study was conducted for the fulfillment of my Master's degree in Development Studies. It had limitations in scope, the timeframe and capacity of interpretation. First, the scope of this case study was limited to four selected schools so findings cannot be used to generalize the context for either the district or provincial level (Yin, 2011). It was a small study that reflected the real experience of community participation in education in certain school communities. Even so, some new information has been generated from this study to add to what is known about community participation in Cambodia

The objective of the study was limited to the forms and processes of community participation in education at primary school levels, and the community mobilization techniques employed by the schools and SSCs. The study did not include aspects of participation above primary school level. To respond to the research objectives, I interviewed a limited number of participants in the community. I did not include the children in the study but some general observations of children's work and activities were carried out. In addition, some documents that I intended to collect from NGOs were not accessible because of the restrictions of the NGOs. I was able, however to obtain supplementary information from the interviews with NGO staff.

Secondly, this study was conducted over 12 months from February 2015 to February 2016. Statistics on student numbers were collected from the four schools and verified with the data from DoE, however the data available was from the fiscal year 2013-2014 even though some communes had updated data in 2014-2015. Thus, this case study investigated during 
this period had some limits (albeit minor) in accessing secondary data that was relevant to the time of the data collection.

Third, my interpretation was influenced by my identity, my educational background, my working experience, and my existing knowledge about education. I used interpretivism as the epistemological worldview in which to interpret my research, recognizing its subjective nature. My interpretations of the data were influenced by my identity in coming from a developing country, my work experience with the poor, and my empirical knowledge and practical experience. I have also been influenced by the Western education system in which this thesis is theoretically based. Thus my analysis is based on both empirical experiences and theoretical understandings.

\subsection{Ethical Issues}

The principle of ethical social scientific research is the notion of doing no harm (Bruce, 2009). I considered a range of possible ethical issues such as the importance of respecting research participants, causing no harm to participants and the Victoria University of Wellington (VUW), and being transparent with research participants, myself and VUW (VanderStoep \& Johnson, 2009). The local people wherein my research was conducted were sensitive to the politics especially between pro-government and anti-government factions. Thus, I told them clearly that I was not related to politics and their confidential information would not be reported.

Both signed and verbal consents were used with the researched. Prior to the interviews, consent information sheets were read to get research participants informed about the purposes of the research. Then, I read and explained the consent form for the illiterates before interviewing ${ }^{14}$. Some participants agreed to sign consent forms; whilst illiterates agreed to use verbal consents. In addition, in the focus group discussion, I reminded them that the group members should keep the confidentiality of their fellow group members.

\footnotetext{
${ }^{14}$ It was necessary to read and explain as some of the researched were illiterate. Most participants consented to the interview, but they did not sign the consent forms.
} 


\subsection{Positionality}

Positionality is a reflection process on the position a researcher chooses to adopt in relation to the subject, participants, context, and the processes of a research or development project (Hopkins, 2007). During my field research, I kept in mind about the self ${ }^{6}$ and _other'.

In thinking about my positionality, I considered some critical factors such as my gender, culture, education status, lifestyle, and political and social status and my previous work (Johnson-Bailey et. al., 2001; Hopkins, 2007; Sultana, 2007; Karnieli-Miller, 2009). I had general conversations with participants to build relationship before the interviews (Peake \& Trotz, 199). In addition, I respected the norms and customs of the community. For example, I paid higher respect to the elderly and monks in the conversations and interviews in line with Cambodian cultural expectations. Political status is another sensitive issue that $\mathrm{I}$ had to consider as the political context in Cambodia is authoritarian and hierarchical. The high position officers deserve and expect higher respect from the public. Thus, I carefully used formal conversation showing high respect with local authorities.

Dressing was another criterion to consider. I had to be flexible with different people (Barker \& Smith, 2001), so I dressed in casual clothes when interviewing community people and parents in order to situate myself at the same level as the participants. In contrast, I dressed in a smart uniform when I conducted interviews with school directors, teachers, local authorities and NGO staff because they were either professionally or semiprofessionally dressed. This could help me and the researched share a certain level of power in the conversations.

\subsection{Validity and Reliability Issues}

The validity and reliability of this research was a serious consideration at all stages (Kitchin \& Tate, 2000). In thinking about validity, I considered both theoretical and practical issues. Regarding theoretical issues of validity, before I selected the theoretical frameworks (community participation and involvement frameworks), I consulted with a number of books, journals, research documents and my supervisor. As stated in Chapter 2, the community participation typology and involvement frameworks are recognised in the field 
as valid theoretical tools and have been tested by numerous researchers and research institutions. In addition, these frameworks have been applied in different contexts and sectors.

To enhance the soundness of the investigation, I used multiple forms of data collection with a range of research participants from different sectors of the education community. The variety of data collection methods provided me with chances to triangulate the data for the research which resulted in good information for analysis and interpretation.

With regards to the reliability of the study, I always checked the consistency of the information collected from the field. During the interviews or discussion for example, I clarified the answers from participants before going further to the next question.

\subsection{Conclusion}

In order to investigate the participation of the local community in education, a case study approach was used in four selected primary schools and four school communities in a rural region of Cambodia. Information from different perspectives was pursued through mixed methods of data collection. Interviews were the main tools to obtain information within the community. The employment of multiple tools for data collection and the selection of people from different sectors strengthened the validity and reliability of the study.

The information collected from different sources was analyzed and interpreted with an interpretivist approach. Even though this epistemological approach was subjective, positionality and reflexivity were considered to minimize unintentional bias. 


\section{CHAPTER 5}

\section{COMMUNITY PARTICIPATION IN EDUCATION IN REMOTE PRIMARY SCHOOLS IN CAMBODIA}

\subsection{Introduction}

This chapter presents the findings of the data collection to answer the research question of how community participation in education is occurring in the remote primary school of the Samlot district in Cambodia. The research project had specific questions which were concerned with the perception of the research participants towards various aspects of community participation. These included exploring the types and processes of community participation, community mobilization approaches and the degrees of community participation. The central research question was answered by analyzing the responses to these specific questions.

\subsection{Range of Education Stakeholders}

The identification of education stakeholders in this research is central to answering the main research question as it has been important to identify the relevant people and institutions involved in schools and education. The term education stakeholders ' refers to the people, institutions or organizations that participate at various levels in education.

The data from the interviews was from governmental organizations, non-governmental organizations, religious institutions, community-based organizations, clubs, committees, for-profit organizations and individuals in the communities (see Figure 11). Each group of education stakeholders had different levels and frequencies of participation in education. The data from the interviews with school directors was consistent with the Student Councils, parents, SSCs, District Office of Education (DoE), village leaders, Buddhist pagodas and NGOs who had frequent participation in education. The rest of education stakeholders were reported as having occasional participation. 
Figure 11: Range of identified Educational Stakeholders

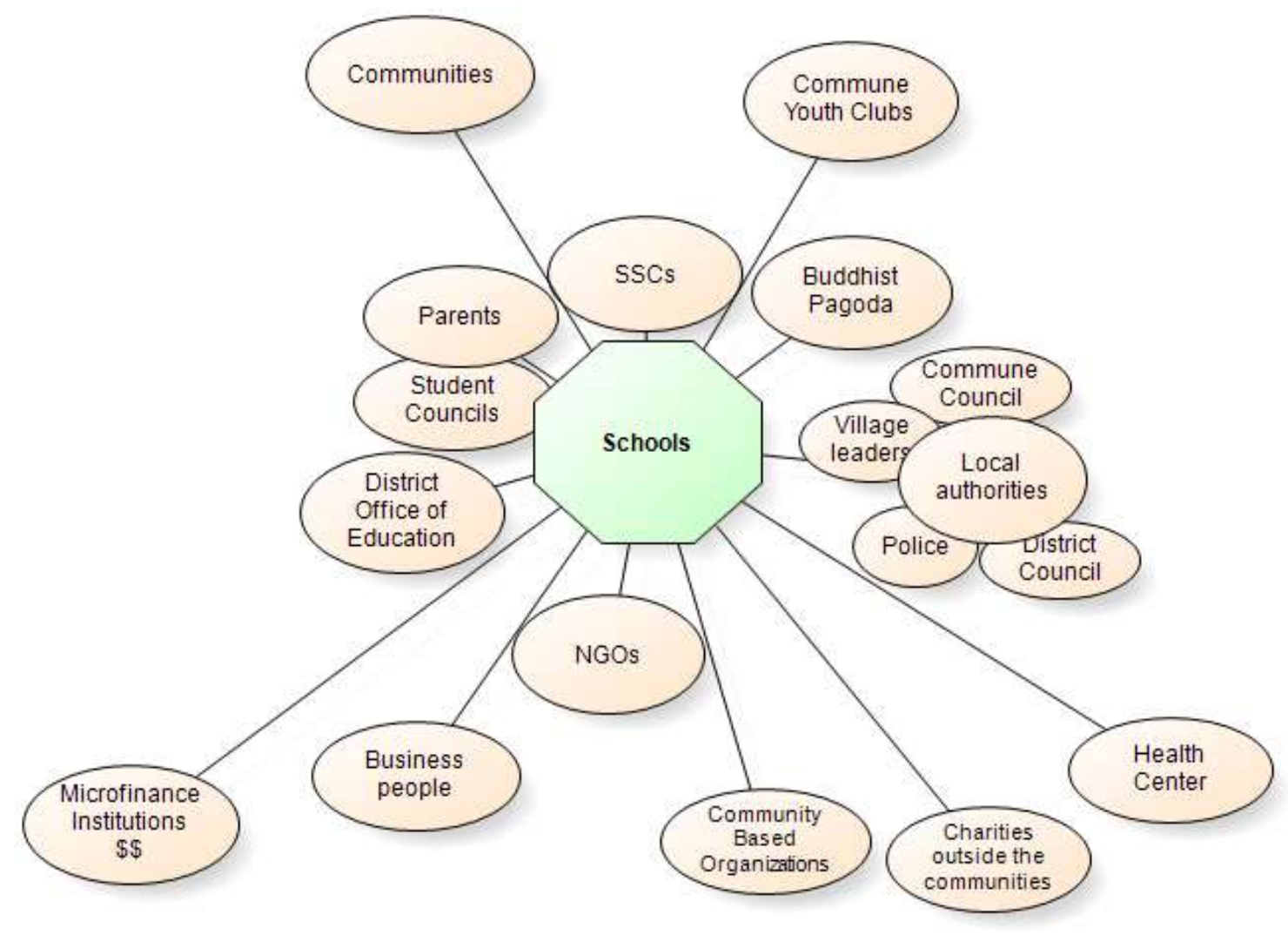

Each of the education stakeholders participated in the schools and education in different ways which are further explained later in this chapter.

\subsection{Perceptions about Community Participation in Education}

Since this research is based on an interpretivist epistemology, it is essential to determine the different understandings of the research participants towards community participation in education. This helps to discover how local people constructed their understandings about participation in education. Interpretivism contends that the different ways in which the world is viewed arise from the influence of our beliefs, value systems and cultures (Walliman, 2011).

The data from the interviews and discussion show that each group of participants had different perceptions about community participation in education. Their diverse understandings are reported in Table 8. 
Table 8: Perspectives of Participants on Community Participation in Education

\begin{tabular}{|c|c|}
\hline Respondents & Perceptions towards Community Participation in Education \\
\hline $\begin{array}{l}\text { School } \\
\text { directors }\end{array}$ & $\begin{array}{l}\text { Community participation in education is a process involving parents, authorities } \\
\text { and education relevant stakeholders in education. This involvement occurs in the } \\
\text { form of ideas, money, materials and labour contribution for school development. }\end{array}$ \\
\hline Teac & $\begin{array}{l}\text { Community participation in education is the participation in receiving education } \\
\text { information from schools and spreading in the community. Community } \\
\text { participates through sending their children to schools and contributing ideas, } \\
\text { money and materials whenever the school asks for help. }\end{array}$ \\
\hline SSC & $\begin{array}{l}\text { Community participation in education is the processes of receiving and spreading } \\
\text { education information in the community. It is the process of mobilizing resources } \\
\text { in the communities for school improvement. }\end{array}$ \\
\hline Parer & $\begin{array}{l}\text { Community participation in education is the contribution of money, materials, } \\
\text { labour and ideas for school improvement such as school construction, and } \\
\text { sending children to school and helping children learning at home. }\end{array}$ \\
\hline $\begin{array}{l}\text { Local } \\
\text { Authorities }\end{array}$ & $\begin{array}{l}\text { Community participation in education is the involvement in spreading education } \\
\text { information and value of education to local authorities and community in order } \\
\text { to get children get education. Community participates through resource } \\
\text { contribution such as money and labour for school and education development. }\end{array}$ \\
\hline NGOs & $\begin{array}{l}\text { Community participation in education is the contribution of materials, labour, } \\
\text { money, time and ideas from communities for school and education development. }\end{array}$ \\
\hline $\begin{array}{l}\text { Religious } \\
\text { leader }\end{array}$ & $\begin{array}{l}\text { Community participation in education is the participation in the discussion to } \\
\text { identify weaknesses of the school for improving children's learning. }\end{array}$ \\
\hline
\end{tabular}

Overall, even if the participants had different understandings, a common view on community participation was resource contribution such as material, money, and labour. The diverse understandings of the research participants on community participation in education which were mentioned above are interrelated with each type of Epstein's participation frameworks, and their understandings were also correlated with the behaviors of the community towards the participation in education which are reported in the next section. 


\subsection{Types and Processes of Community Participation in Education}

Results of the study indicate that the behaviors of the community towards education occurred in various forms by different education stakeholders. This section presents the research findings relating to the different forms of participation taking place, and how each form of participation has emerged. Epstein's (1995) participation framework was used as an analytical tool.

\subsubsection{Parenting}

With regard to parenting, families are basically held responsible for educating their children in the basic skills, knowledge, norms, behaviors, values and beliefs of the families and society (Bornstein, 2005). To assist families, Epstein's framework suggests the schools provide assistance to the families with parenting and childrearing skills, knowledge about child development stages and the home-setting for children's development (Epstein, 1992, 1995, 2006).

The study found some parenting activities carried out by parents and some parenting assistance undertaken by the schools. The participation in parenting in children's education occurred with parents, caregivers such as guardians and siblings, and children's relatives. Parenting activities of both parties were for serving children's learning. The table below indicates the main parenting activities undertaken by parents/caregivers and the schools.

Table 9: Parenting Activities

\begin{tabular}{|c|c|}
\hline Parents' parenting activities & Schools' parenting support \\
\hline $\begin{array}{l}\text { Parent made their children's accessibility to education } \\
\text { through: } \\
\text { - } \quad \text { Enrolled children in schools } \\
\text { - Ensured their children's attendance in schools } \\
\text { - } \quad \text { Accompanied small children during classes to get } \\
\text { them used to the schools }\end{array}$ & $\begin{array}{l}\text { Schools conducted education/enrollment } \\
\text { campaign } \\
\text { - Informed education information in the } \\
\text { community } \\
\text { - Encouraged parents to participate in } \\
\text { their children's learning }\end{array}$ \\
\hline $\begin{array}{l}\text { Pertained information about their children's learning } \\
\text { progress from teachers } \\
\text { - } \quad \text { Suggested teachers to provide extra support to their } \\
\quad \text { children } \\
\text { - } \quad \text { Suggested teachers to give them teaching methods }\end{array}$ & $\begin{array}{l}\text { Updated children's learning progress with } \\
\text { parents through student study records, } \\
\text { meetings and occasional conversations } \\
\text { - Helped parents with basic teaching } \\
\text { techniques to help children at homes. }\end{array}$ \\
\hline $\begin{array}{l}\text { Helped children with their daily schooling } \\
\text { - } \quad \text { Prepared children to dress up with tidy uniforms, } \\
\text { appropriate hair } \\
\text { - Prepared learning materials such as notebooks, } \\
\text { textbooks and pens and so on for children. }\end{array}$ & $\begin{array}{l}\text { Consulted with parents about children's } \\
\text { safety and security at schools and in } \\
\text { communities. } \\
\text { - Encouraged parents to pay attention on } \\
\text { their children's school attendance. }\end{array}$ \\
\hline
\end{tabular}


Communities, particularly parents, participated in their children's schooling through making the education accessible to their children. According to the results from the survey, $98 \%$ of parents reported going to the schools for enrolling their children at the beginning of the academic year. In addition, in order to retain children's school attendance, some parents dropped their children off at school and picked up them after classes every day (FGD with parents, Aphiwat Samlot, 01/06/2015), and some parents accompanied their little children to the classes and stayed with their children for a while to observe their children's learning (observation, Aphiwat Samlot, 01/06/2015). I also observed that parents, older brothers/sisters and relatives of the small children came to pick up small children at the end of their classes. According to my observation and FGDs with parents, only parents/caregiver who had little children did these activities.

The study also found that parents and caregivers consulted with teachers about their children's learning progress. The parents in the FGDs mentioned that they consulted with classroom teachers frequently about their children's learning progress and suggested teachers provide extra support such as paying more attention on their children's learning (FGD, 01/06/2015).

Parents were found performing their parenting roles in their children's schooling. Parents and caregivers were told by a teacher that they should pay attention to their children's schooling by preparing children for daily learning such as having appropriate clothes and learning materials for their children (Sre Reach teacher, interview, 25/05/2015).

I observe that most students in my school have a tidy uniform and an appropriate haircut. This means that parents and caregivers of those children provide supports for their learning (Sre Reach teacher, interview, 25/05/2015).

The study has not found any specific parenting programs implemented within the selected schools. Instead, according to the interview with Aphiwat Samlot school director (11/05/2015), the schools kept updating children's learning progress with their parents through student study records and verbal communication. He also suggested parents pay attention to their children's learning. A teacher from Sung 1 and Sre Reach also provided consistent responses that the schools usually suggested parents help and encourage their children to study at home and to teach morals to the children at home (interviews, 
$19 / 05 / 2015,25 / 05 / 2015)$. They also suggested parents come to the schools to talk about children' learning.

Teachers usually gave parents informal consultations about learning and the safety of the children in schools. According to the Aphiwat Samlot school director and my observations, the school had formed a student group to coordinate traffic in order to protect children from traffic accidents after class (observation and personal communication, 11/05/2015). According to the school director, this activity gained satisfaction from parents and local authorities.

The above parenting activities were carried out by parents, caregivers and teachers which occurred in different procedures. It served the children's education purpose. Likewise, the participation of the parental involvement in assisting children learning at home was found in the study.

\subsubsection{Learning at home}

This is a form of participation that involves the activities where families assist their children's learning at home such as homework and other curriculum-related activities. Teachers can provide basic knowledge about teaching to parents so that they can assist their children learning (Bornstein, 2005). Teachers can design homework that promotes the discussion that involves children and their parents (Epstein, 1992, 1995, 2006; Epstein \& Salinas, 2004).

With regard to leaning at home, the study found a variety of activities that parents had to support their children's learning. According to questionnaire survey results, in response to the question of how communities and families support their children's learning, all participants responded that they provided support to their children learning at home. Table 9 shows three categories of parent activities supported children's learning. The table shows that $25 \%$ of parents helped their children with teaching and encouraging children, and checking their children's learning materials; 37\% of parents helped with encouraging children to study and by checking their study record; and $38 \%$ of parents responded that they help only by telling children to focus on studying. 
Table 10: Parental Activities at Home

\begin{tabular}{|l|r|}
\hline Parents' participation in children's learning at home $(\mathbf{n}=\mathbf{4 0})$ & $\%$ \\
\hline $\begin{array}{l}\text { Teaching children, encouraging children to study, and checking student academic record } \\
\text { and notebooks }\end{array}$ & \\
\hline Encouraging children to study and checking study records & $25 \%$ \\
\hline Telling children to focus on studying & $37 \%$ \\
\hline Total & $38 \%$ \\
\hline
\end{tabular}

Even if the survey results indicated the participation of parents in supporting their children learning at home such as teaching activities at home, the study did not explore how frequently they undertook these activities.

The focus group discussions with parents provided more information about parental involvement in their children's learning. The FGD results show that the most common activities parents had at home were encouraging their children's learning, but it was less common that they got involved in teaching their children. The response of Aphiwat Samlot school director was consistent with this finding. He told me that:

Not all parents helped their children's learning. Parents who have themselves had an education and who have better living standards paid more attention to supporting children's learning at home.

[....... some parents follow up their children every day. Parents in the market bloc paid more attention on their children's learning. Those parents usually checked with their children's teachers about the homework that their children have (Aphiwat Samlot school director, interview, 11/05/2015).

The information from the interview with the school directors is likely to be more valid as it was reflected in findings from the FGDs with parents. Parents from Aphiwat Samot said that:

We taught our children at home, checking daily homework and notebooks, followed up children's learning and went to talk with teachers about our children's learning. Sometimes we came to talk to the teachers about the lessons and asked for an explanation from the teachers so that parents could help teaching their children at homes (FGD with parents, Aphiwat Samlot, 02/06/2015). 
The common tasks we regularly did with regards to their children's learning after school were encouraging children to study hard and told them to do reading before bedtime (FGD with parents, Sung 1, 03/06/2015).

Despite the survey and FGD results indicating the engagement of the parents in supporting children's learning, the school director and teachers from Dauntret expressed their concerns about less attention of parents in supporting their children learning and that parents focused on their own work rather than their children's education (interview, 18/05/2015). The results of the questionnaire survey provided similar information that $50 \%$ of parents blamed other factors such as being poor and too busy to get involved in their child's education.

Table 11: Obstacles of Participation in Education

\begin{tabular}{|l|c|}
\hline Obstacles of participation in education $(\mathbf{n}=\mathbf{4 0})$ & $\%$ \\
\hline Busy at work & $35 \%$ \\
\hline Living conditions & $15 \%$ \\
\hline No obstacles & $50 \%$ \\
\hline Total & $100 \%$ \\
\hline
\end{tabular}

The Dauntret school director told me that:

Most families are poor and they usually leave their home to work in the farms and they return in the evening. They are too tired to help their children's learning (Dauntret school director, interview, 18/05/2015).

The interviews with school directors and teachers show that teachers encouraged parents to have conversations with teachers about their children's learning and teaching methods so that they can assist their children learning at home. For example, a librarian from Dauntret showed his passion to get parents involved in helping children's reading. He encouraged parents to come and observe their children's reading in the library so that they could help their children at home. Some parents were happy to see their children's reading (Dauntret teacher, interview, 18/05/2015).

The study also found the support from Buddhist monks in getting parental involvement in education. In the community Buddhist monks usually advised communities and parents to assist children learning at home. A monk leader from Aphiwat Samlot community told that: 
I usually educate families and children in the community not to be addicted to TVs programs. Rather, parents should encourage children to study hard, and parents should send their children to schools (Monk leader, interview, 12/05/2015).

The responses of the monks indicate the intervention of religious institution in supporting children's learning at home and in the communities. Likewise, communicating is another type of participation in education, which served children's learning purpose that the study has found occurring in the selected community.

\subsubsection{Communicating}

This type of participation refers to the communication between the schools and families about the education program and the children's learning progress at school (Bornstein, 2005). Typical means of communication which vary between schools are memos, notices, phone calls, report cards, and letters and so on (Bornstein, 2005). Two-way communication is an effective method in sharing information about children's learning progress between the schools and families (Epstein, 1992, 1995, 2006).

According to the interview data and my observation, the schools and communities used several methods of communication to send and receive information to/from the communities/schools, and the communication occurred in multi-dimensions (schoolfamily-community). The study identified three main aspects of communication between the schools and communities: school-to-community communication, community-to-school communication and the agent of communication.

School-to-community communication: The direction of this communication occurred at the schools to the community (included families). According to the interviews with school directors and teachers from the four schools, the schools used both written and verbal communication. Written tools were student study records and communication books which occurred only between teachers and families. Verbal tools were telephones, meetings and community outreach which occurred within schools, families and communities (interviews, $11 / 05 / 2015,18 / 05 / 2015,19 / 05 / 2015,25 / 15 / 2015)$. Each of these means were used in different circumstances which are demonstrated in Table 23. 
Table 12 demonstrates five common means of communication that the four schools used with the communities. The table shows means/tools of communication, characteristics and functions, and disadvantages of each means of communication.

Table 12: Communication Tools in School-to-community

\begin{tabular}{|c|c|c|}
\hline Tools & Characteristics and functions & Difficulties \\
\hline \multicolumn{3}{|c|}{ Written communication } \\
\hline $\begin{array}{l}\text { Student Study } \\
\text { Records }\end{array}$ & $\begin{array}{l}\text { The student study records were used on a monthly basis to track } \\
\text { individual students' achievement in class. Parents were required } \\
\text { to read the reports and then write any comments on their } \\
\text { children's study records before sending back to the schools. }\end{array}$ & \multirow[t]{2}{*}{$\begin{array}{l}\text { Impracticable } \\
\text { with illiterate } \\
\text { parents }\end{array}$} \\
\hline $\begin{array}{l}\text { Communication } \\
\text { Books }\end{array}$ & $\begin{array}{l}\text { These books were used to communicate with parents when } \\
\text { students were absent for several days with no notice, and when it } \\
\text { was difficult to contact parents by phone. These books would be } \\
\text { sent via a student who lived close to the absentee student's } \\
\text { family. }\end{array}$ & \\
\hline \multicolumn{3}{|c|}{ Verbal communication } \\
\hline Telephone Calls & $\begin{array}{l}\text { Each of the four schools used the telephone to contact parents, } \\
\text { communities and local authorities for schooling and education } \\
\text { purposes. The schools called SSCs and local authorities for } \\
\text { formal and informal meetings. } \\
\text { Teachers used telephones to follow up their children's absence. } \\
\text { I observed the four schools had lists of phone numbers of local } \\
\text { authorities. This indicates that the schools used telephone to } \\
\text { communicate with local authorities. }\end{array}$ & $\begin{array}{l}\text { Teachers had } \\
\text { to pay their } \\
\text { own money to } \\
\text { recharge }\end{array}$ \\
\hline Meetings & $\begin{array}{l}\text { The schools sometimes conducted meetings with parents, SSCs } \\
\text { and local authorities to share education information and policies. } \\
\text { At these meetings, the schools can get feedback and comments } \\
\text { from the participants on ways of improving the education } \\
\text { system. }\end{array}$ & $\begin{array}{l}\text { Communities } \\
\text { and parents } \\
\text { were too busy } \\
\text { to join the } \\
\text { meetings }\end{array}$ \\
\hline $\begin{array}{l}\text { Community } \\
\text { outreach }\end{array}$ & $\begin{array}{l}\text { School director sometimes visited } \text { students }^{6} \text { families when } \\
\text { necessary. Classroom teachers sometimes visited, or were } \\
\text { encouraged to visit, students with frequent absence. }\end{array}$ & $\begin{array}{l}\text { Spent much } \\
\text { time to visit } \\
\text { the difficult } \\
\text { places }\end{array}$ \\
\hline
\end{tabular}

The Aphiwat Samlot school director and the Sre Reach school director complained about communication with the community and parents. They said that the use of student study records and communication books which required parents' ability to read and write was generally ineffective for communication with students ' parents who were illiterate.

When teachers wrote student follow up record to the parents, some parents returned with comments on those student study records, but some did not because they did 
not know how to read and write (Aphiwat Samlot school director, interview, $11 / 05 / 2015)$.

The illiteracy of the parents was the barrier of the communication between the schools and communities and families, and it limited the parents' participation in their children's education (Sung 1 school director, interview, 19/05/2015).

It is hard for some parents who are illiterate to follow up their children's learning. For example, we send follow up letter to the family, they do not know how to write or comment, they just return the book blank (Sre Reach school director, interview, 25/05/2015).

Community-to-school communication: This communication had direction from the community to the schools and was carried out by communities or parents. A school director said that parents used telephones to communicate with teachers to receive information about their children's learning (interview, 11/05/2015). This finding was supported by the FGD with parents that parents sometimes contacted the teachers or school director to follow up their children's learning at schools and clarify their children's homework. Some parents called teachers when they did not see the student study records at the end of the month. Some parents called teachers for permission for an upcoming absence (FGD with parents, 02/06/2015).

Some parents visited schools and some were invited to get further education information and information about their children's learning. According to the questionnaire survey, $98 \%$ of parents had been to the schools. Despite this, only $25 \%$ of parents were invited by the schools to assist in planning and consultation meetings, as well as to join the award ceremonies.

Agents of communication: On top of the means of communication above, the study found five groups of community people who were information carriers between the schools and the community. Those information carriers were students, SSCs, Buddhist monks, local authorities and parents who participated in the school. These people spread information about education throughout the villages. 
Table 13 shows five specific groups of communities who carried messages from and to schools. The table includes the agents of communication; how the messages were spread and examples of responses by the research participants.

Table 13: Agents of Communication

\begin{tabular}{|c|c|}
\hline How the messages were spread & Example \\
\hline & Students \\
\hline $\begin{array}{l}\text { Students brought information from the } \\
\text { school to their families. } \\
\text { However, the information carried by } \\
\text { the students was not clearly understood } \\
\text { by the parents and communities. Thus, } \\
\text { some parents called the teachers to } \\
\text { clarify the information. }\end{array}$ & $\begin{array}{l}\text { Classroom teachers told students about fund raising for } \\
\text { school renovation. Students brought the information to } \\
\text { the families. } \\
\text { After receiving information from the children, parents } \\
\text { called teachers to clarify the money contribution for } \\
\text { school repairing the kindergarten (Aphiwat Samlot } \\
\text { school director, interview, 11/05/2015). }\end{array}$ \\
\hline \multicolumn{2}{|c|}{ School Support Committee } \\
\hline $\begin{array}{l}\text { SSC members helped in spreading } \\
\text { information about school activities in } \\
\text { their communities. }\end{array}$ & $\begin{array}{l}\text { SSC leaders brought information about fund raising to } \\
\text { spread in the villages and in the pagoda (Dauntret school } \\
\text { director, interview, 18/05/2015) } \\
\text { SSC members helped to spread education information } \\
\text { during education campaign at the beginning of the new } \\
\text { academic year in order that parents and caregivers } \\
\text { brought their children for enrolment (SSC leader, } \\
\text { interview, 18/05/2015). }\end{array}$ \\
\hline \multicolumn{2}{|c|}{ Buddhist Monks (Religious institutions) } \\
\hline $\begin{array}{l}\text { Monks occasionally helped spreading } \\
\text { the education information in the } \\
\text { communities when they preached in } \\
\text { the Buddhist ceremonies in the } \\
\text { communities. }\end{array}$ & $\begin{array}{l}\text { SSC requested the pagoda to spread the education } \\
\text { information during enrollment campaign in the religious } \\
\text { event. - Soclergymen in the pagoda helped us to spread } \\
\text { the information" (Dauntret SSC leader, interview, } \\
18 / 05 / 2015 \text { ). }\end{array}$ \\
\hline \multicolumn{2}{|r|}{ Local authorities } \\
\hline \multicolumn{2}{|c|}{\begin{tabular}{l|l} 
Village leaders, commune council and & \\
district council spread information & \\
about education and value of education & \\
in the meetings with local authorities. & \\
\end{tabular}} \\
\hline \multicolumn{2}{|c|}{ Participating parents } \\
\hline $\begin{array}{l}\text { Parents who attended the meetings } \\
\text { with teachers and who received } \\
\text { information from the teachers spread } \\
\text { the information in their communities. }\end{array}$ & $\begin{array}{l}\text { - spread the information about the school } \\
\text { development project [electrification of the school] to our } \\
\text { neighbors after attending the meeting" (FGD with } \\
\text { parents, 03/06/2015) }\end{array}$ \\
\hline \multicolumn{2}{|r|}{$N G O s^{15}$} \\
\hline Spread information in their target area & $\begin{array}{l}\text { WVC staff spread the information about education in } \\
\text { meetings with local authorities and communities and } \\
\text { encouraged parents to assist their children's learning at } \\
\text { home. }\end{array}$ \\
\hline
\end{tabular}

${ }^{15}$ World Vision Cambodia and Khmer Education Network 
This table indicates that students and communities who had participated in schools to some extent were involved in spreading and interpreting information within their communities. These groups were the connectors, agents, interpreters and mediators between the schools and communities who were found supportive for children's education. This section can be summarized that communication was predominantly initiated by the schools rather than by the communities. Despite this, the communication process was assisted by students, communities, and parents who participated in the schools.

\subsubsection{Volunteering}

Volunteering concerns the involvement of parents and others volunteered to assist teachers, administrators, and children in classrooms or in other areas of the school to improve quality of education and children's learning (Epstein, 2006). Parents, community members and others come to schools to support student performances, sports, or other events. Epstein suggested schools recruit and train volunteers so that they are helpful to teachers, students, and school improvement efforts at school and in other locations (Epstein, 1992, 1995, 2006).

Through my observations, all the four schools had two formal groups each that carried out volunteering work for the schools: the School Support Committee (SSC) and the Student Council (SC). SSCs were formed or reformed annually (DoE deputy director, interview, 22/05/2015). I collected relevant documents from the four schools and DoE to review. I observed that all four schools had the same SSC structures as shown in Figure $12^{16}$. According to the School Development Plans (SDPs) of the schools, even if the four schools had the same SSC structures, each of SSCs had mixed and different components ranking from commune council, village leaders, monks, clergymen/women to retired teachers and teachers (Aphiwat Samlot, 2014; Sung 1, 2014; Sre Reach, 2014) ${ }^{17}$. These committees had roles in supporting the school operation and mobilizing community resources for school and education development (MoEYS, 2015).

\footnotetext{
16 The four schools had SSC structures displayed on the office walls and documented in the school offices.

${ }^{17}$ SDP from Dauntret was not available but the structures of SSC and SC were seen in the office.
} 
Figure 12 and Table 14 show the similar SSC structures and the components of the SSCs of the four schools. Figure 12 shows the hierarchy of the SSCs while Table 14 depicts mixed components of SSC members.

Figure 12: Structure of School Support Committee

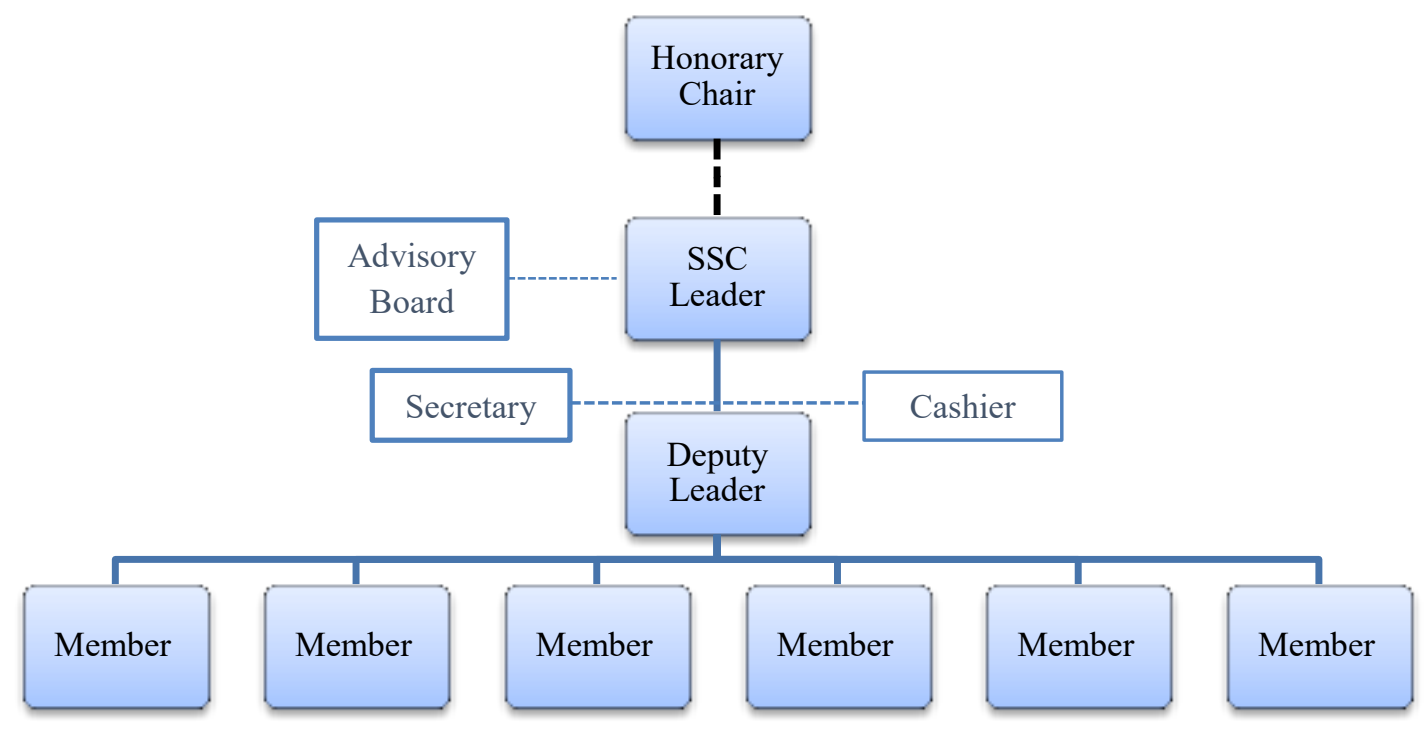

Table 14: Mixed Components of School Support Committee

\begin{tabular}{|llll|}
$\begin{array}{l}\text { School } \\
\begin{array}{l}\text { Aphiwat Samlot } \\
\text { (10 SSC } \\
\text { members) }\end{array}\end{array}$ & $\begin{array}{l}\text { SSC leaders } \\
\text { Former school } \\
\text { director }\end{array}$ & $\begin{array}{l}\text { Advisory board } \\
\text { Buddhist monk leader, } \\
\text { commune council member, } \\
\text { school director }\end{array}$ & $\begin{array}{l}\text { Deputy and Members } \\
\text { Commune council member, } \\
\text { teachers, parents, deputy } \\
\text { village }\end{array}$ \\
\hline $\begin{array}{l}\text { Dauntret } \\
\text { (11 SSC } \\
\text { members) }\end{array}$ & Village leader & $\begin{array}{l}\text { Buddhist monk leader, } \\
\text { school director, retired } \\
\text { teacher }\end{array}$ & $\begin{array}{l}\text { Deputy village, teachers, } \\
\text { village assistant, parents }\end{array}$ \\
\hline $\begin{array}{l}\text { Sung 1 } \\
\text { (11 SSC } \\
\text { members) }\end{array}$ & Village leader & $\begin{array}{l}\text { Commune leader, Buddhist } \\
\text { monk leader, school } \\
\text { director }\end{array}$ & $\begin{array}{l}\text { Village deputy, village } \\
\text { assistant, village health } \\
\text { support volunteer, parents, } \\
\text { village development leader }\end{array}$ \\
\hline $\begin{array}{l}\text { Sre Reach } \\
\text { (10 SSC } \\
\text { members) }\end{array}$ & Village leader & $\begin{array}{l}\text { Commune leader, school } \\
\text { director }\end{array}$ & $\begin{array}{l}\text { Village deputy, village } \\
\text { assistant, parents, village } \\
\text { development leader }\end{array}$ \\
\hline
\end{tabular}

Overall, SSC leaders were village leaders except for Aphiwat Samlot school. Commune leaders and Buddhist monk leaders voluntarily played advisory roles, as did deputy village leaders and community members who were also members of the SSCs. These SSC members were the representatives of the communities in the schools. 
I observed that Student Councils (SCs) consisted of mixed ages and genders from different grades in which student representatives from grade 3 to grade 6 were elected for SCs every year. The Aphiwat Samlot primary school director told that the council was helpful for school and education development (interview, 11/05/2015). As shown in Figure 13 below, SCs were grouped, and each of the groups had specific tasks to perform such as enhancing school regulation; assisting classroom teaching and learning; emergency tasks for any incidents in the schools; administration and finance activities such as involving soliciting money; information; arts and culture; hygiene, sanitation, environment and sports; and children`s club.

Figure 13: Structure of Student Council

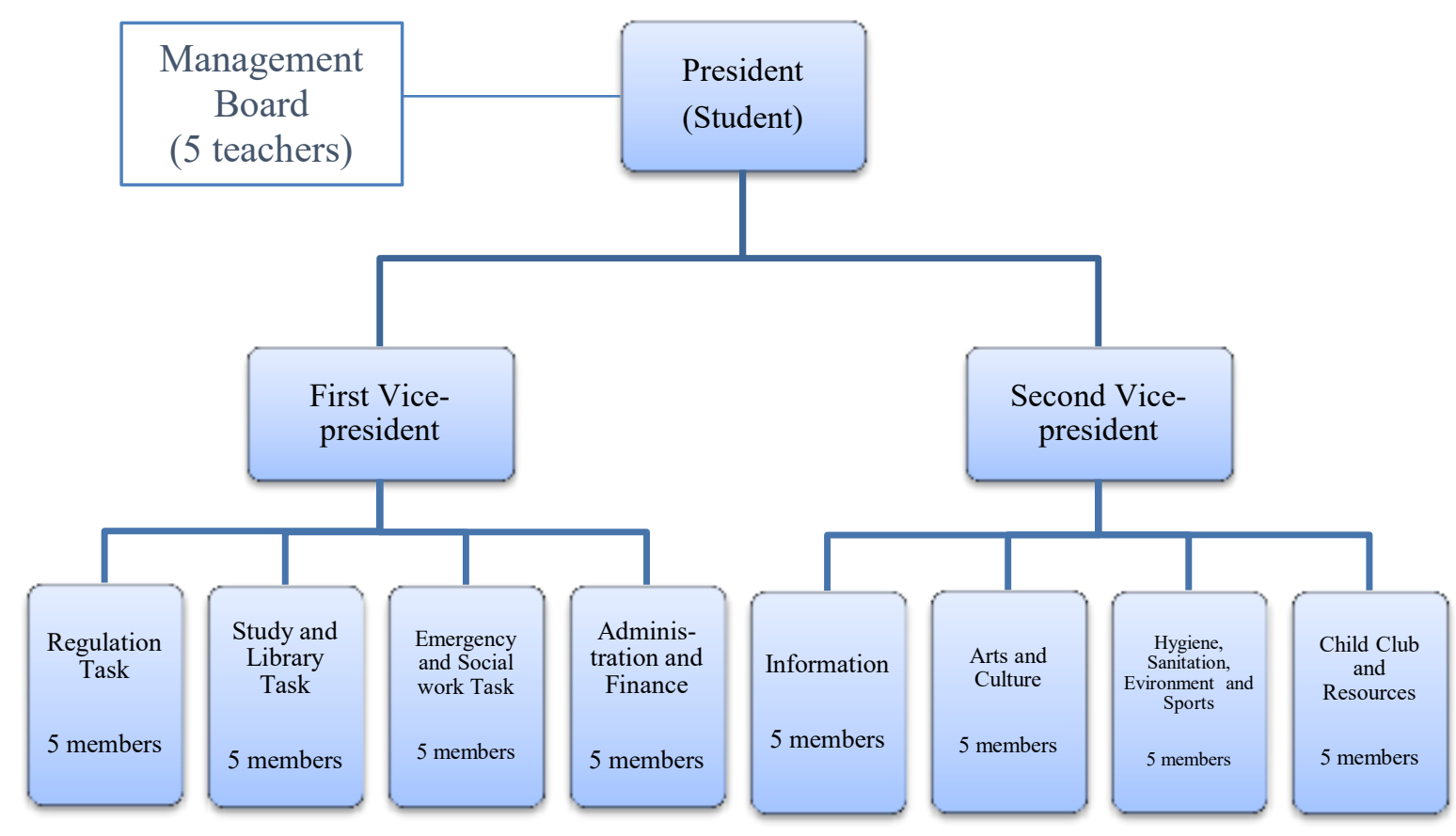

SC members performed their tasks voluntarily for the school and education development. The Aphiwat Samlot school director told me that SC helped teachers in cleaning the environment, such as cleaning the toilets and helped to strengthen the school regulations (Aphiwat Samlot school director, interview, 18/05/2015).

The research did not find any kinds of volunteering efforts by communities and parents in assisting teachers in curriculum-related activities. However, communities and parents did 
participate in the schools through providing training, attending school events, meetings and implementing school activities. Table 15 highlights the voluntary activities individuals and groups of people were involved with in the schools and education.

Table 15: Voluntary Activities

\begin{tabular}{|c|c|}
\hline $\begin{array}{l}\text { Communities/ } \\
\text { groups }\end{array}$ & Volunteering activities \\
\hline $\begin{array}{l}\text { School } \\
\text { Support } \\
\text { Committee }\end{array}$ & $\begin{array}{l}\text { SSCs had three formal meetings every year: at the beginning, mid-year and at } \\
\text { the end of the academic year. The meetings were conducted to develop school } \\
\text { development plan, monitoring and follow up the plan (interview with school } \\
\text { director and SSC leaders). } \\
\text { Fund raising and school development activities. } \\
\text { Looking after school properties } \\
\text { SSC leaders actively participated in the schools both in formal and informal } \\
\text { meetings with the teachers (interview with school directors). }\end{array}$ \\
\hline $\begin{array}{l}\text { Student } \\
\text { Council }\end{array}$ & $\begin{array}{l}\text { Worked in the schools at improving the school environment, aspects of } \\
\text { sanitation, discipline, learning, sports and child safety both in the schools and in } \\
\text { the communities }\end{array}$ \\
\hline Youth Club & $\begin{array}{l}\text { Youth club volunteered in sharing knowledge to the young students in the } \\
\text { schools and raised awareness about social issues in the communities (interview } \\
\text { with World Vision staff). } \\
\text { World Vision Cambodia support these youth groups to raise awareness on } \\
\text { issues such as child protection, domestic violence, hygiene and sanitation and } \\
\text { raised the value of education to parents, children and young people in both the } \\
\text { community and schools within the commune (interview with WVC staff). }\end{array}$ \\
\hline Parents & $\begin{array}{l}\text { Parents were reported coming to schools when they were invited for events such } \\
\text { as the school opening ceremony, school closing ceremony and awards } \\
\text { ceremony for outstanding students. }\end{array}$ \\
\hline $\begin{array}{l}\text { Local } \\
\text { Authorities }\end{array}$ & $\begin{array}{l}\text { Local authorities usually participated in the main events in the schools as part of } \\
\text { an honorary board (Sung commune leader, interview, 20/05/2015). }\end{array}$ \\
\hline $\begin{array}{l}\text { Buddhist } \\
\text { Monks and } \\
\text { Clergymen/ } \\
\text { women }\end{array}$ & $\begin{array}{l}\text { Buddhist monks participated in the meetings in the schools and in disseminating } \\
\text { the education information in the community (interviews with SSC leaders). } \\
\text { I have attended the meeting with Aphiwat Samlot primary school for two times } \\
\text { this year. The meetings were about the discussion about budget expenses which } \\
\text { supported by the MoEYS (monk leader, interview, 12/05/2015). }\end{array}$ \\
\hline
\end{tabular}

In Figures 14 and 15, children are involved in cleaning the roadside environment and coordinating traffic safety for small children after class. 
Figure 14: Children's Volunteering Activity

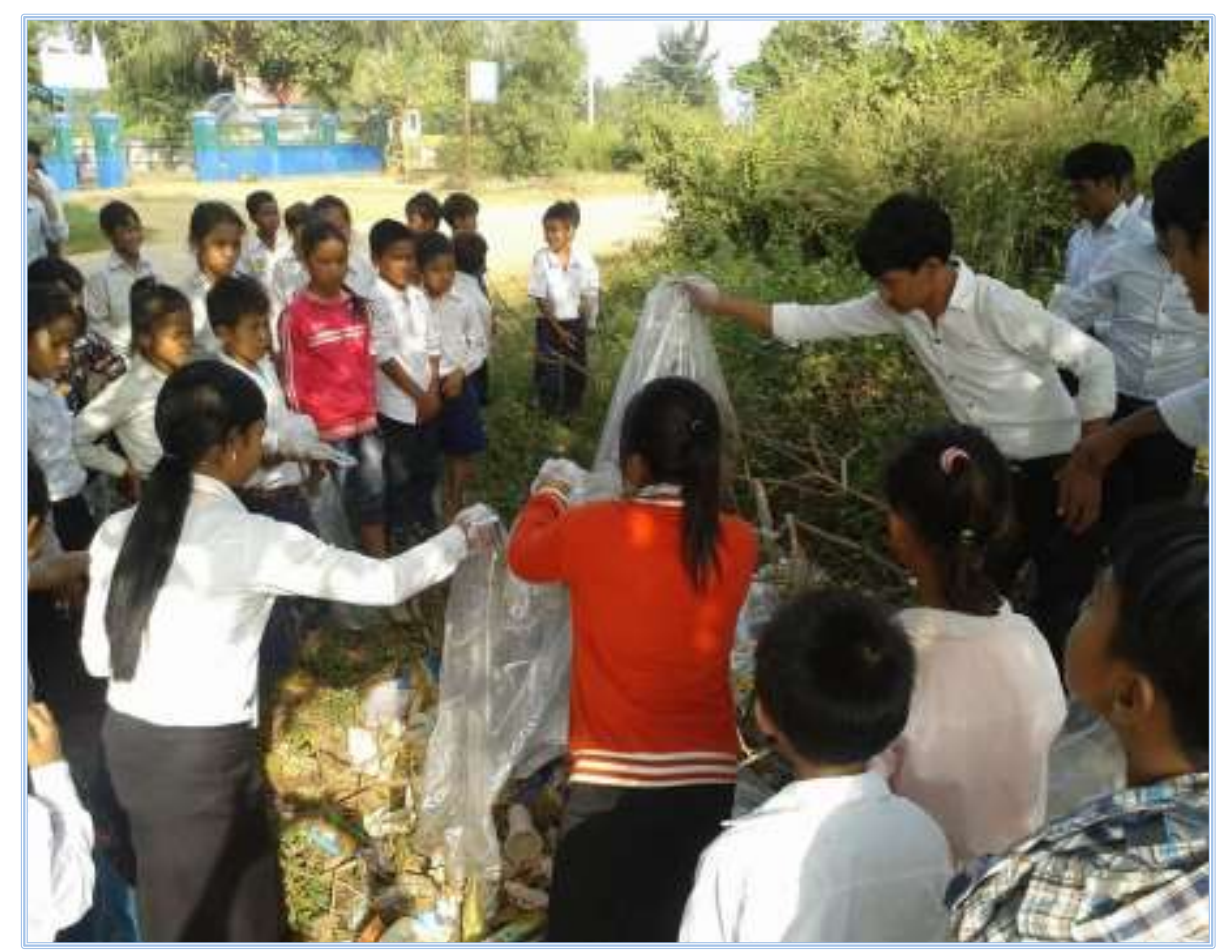

Source: Aphiwat Samlot, 2015

Figure 15: Children Coordinate the Traffic after Class

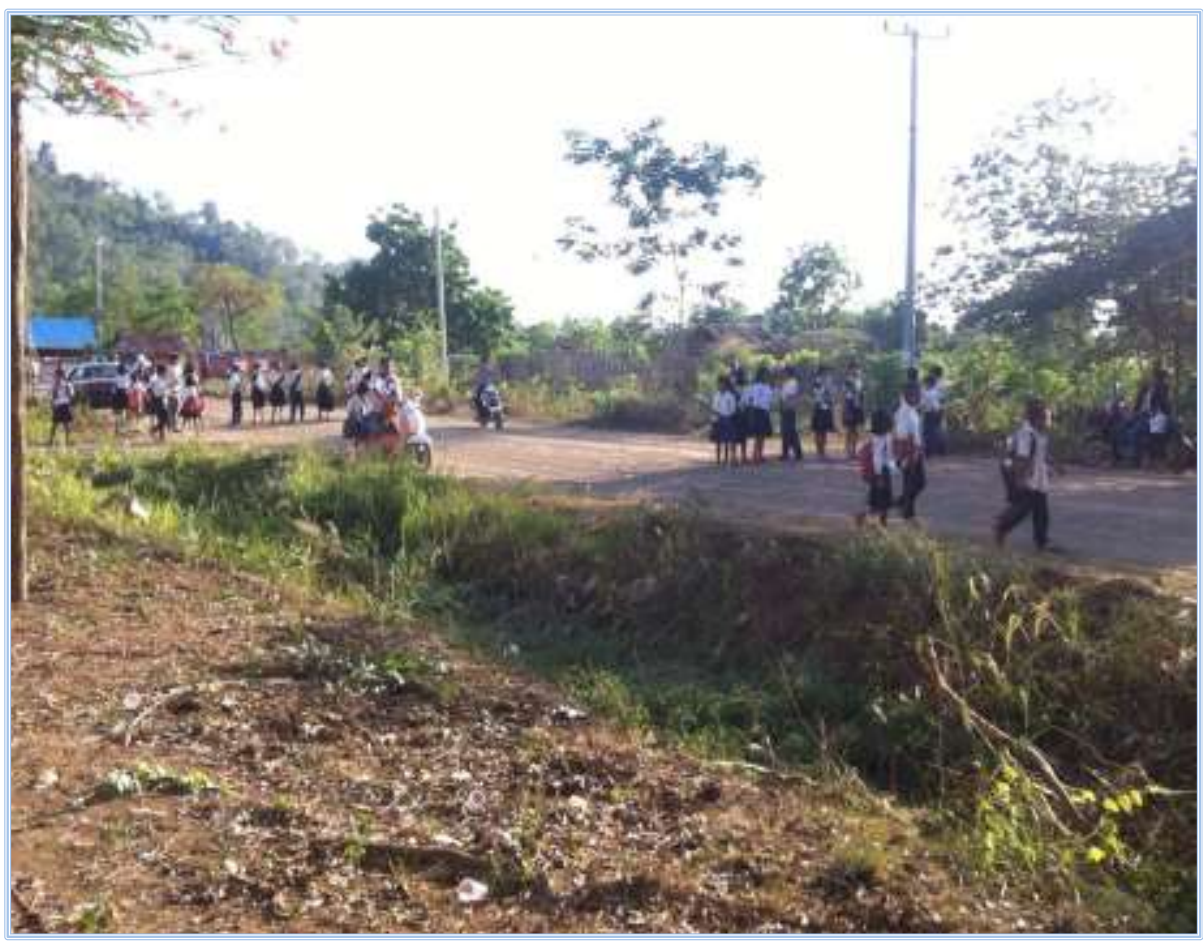

Source: The author, Aphiwat Samlot, 2015 
In general, the study found different groups of communities voluntarily participated in their schools through different types of activities both in the school and the community. Those communities included local authorities and parents who were members of SSCs as well as children and youth groups.

\subsubsection{Decision-making}

Participation in the decision-making process is the involvement of parents and community members in school decisions, governance, and advocacy activities for school and education development through the school committee (Epstein, 1992, 1995, 2006; Epstein \& Salinas, 2004).

The interview data shows that communities in the research area participated in decisionmaking through the School Support Committee (SSCs). As reported in sub-section 5.4.4 above, SSCs consisted of mixed components including local authorities, religious leaders, retired teachers and parents. As members of SSCs, these people had roles and responsibilities in the decision-making in the schools they were elected to work for. Based on the guidelines of MoEYS (2012), the SSC is purposefully formed as a representative of parents and communities in the schools and it plays roles in the decision-making and governance in the schools.

The study found that SSCs participated in the decision-making in school/education management. According to the interviews with the four school directors, SSCs participated in developing annual school development plans (SDPs), implementing and monitoring SDPs. The Aphiwat Samlot school director commented that the SSC leader and its members were invited to join formal meetings with teachers to develop school development plans at the beginning of the academic year (interview, 11/05/2015).

Last year we planned to build concrete school yard to stop soil erosion and muddy school compound, but communities (SSC) prioritized putting Buddhist statues in the school because they had a strong belief in Buddhism. They thought children who could not go to Buddhist pagoda could pray at school. We did not oppose their ideas because communities were the main sources of budget for school development (Sre Reach school director, interview, 20/05/2015). 
This finding shows that communities ' ideas were respected and prioritized for planning for school and education development. This finding was consistent with the responses of SSC leader from Sung 1.

[...] in the planning stage, $\mathrm{SSCs}^{6}$ ideas were suggested by the schools to include into the SDP. SSCs ${ }^{6}$ ideas in the meetings were respected (Sre Reach school director, interview, 20/05/2015).

[... ] I was the one who initiated the plan. When the school playground was muddy in the rainy season (no concrete playground), I saw mud stained on the walls. Then I discussed with the former director about the issue (only two of us). Then, we set up a meeting with teachers and community. We got the consensus in the meeting to build a concrete playground (Sung 1 SSC leader, interview, 19/05/2015).

According to his comments, the Sung 1 SSC leader shared his responsibilities and roles in the decision making for school and education development.

SSCs were reported as being involved in the school administration and budgeting. According to the budget guidelines of MoEYS, the schools could not use the government grants without the acknowledgement or involvement of SSCs (MoEYS, 2015). All school development plans and budget plans were made with the involvement of teachers and SSCs (School Development Plan, 2014-2015). A Buddhist monk leader, who was a member of SSC reported participating in budget planning and fund raising. He told me that:

This year I have attended two meetings with the school, one was about the school development plan and another one was about planning budget given by MoEYS and NGOs (Monk leader, interview, 12/05/2015).

The Sung 1 school director showed me the documents on which SSC signed for purchasing materials for electrification for the school which indicated the participation of the communities in budget spending. On top of that, during my visit to Aphiwat Samlot primary school, the teachers invited a SSC leader to witness the money solicited from the community. These two examples show that the SSCs are involved in the budget management and budget expenses for school development. 
The research found that SSCs particularly the leaders had significant power in the decision making process in school development. Two school directors provided similar responses that SSC leaders were influential.

SSC leader is an important person in the school and the community; he has power of mouth as he is a village leader who has power over community members and he is an old, respected person. He always quickly responds to the school needs such as doing fund raising for school maintenance and looking after the school because he lives next door to the school (Sre Reach school director, interview, 20/05/2015).

The SSC leader has power in the communities. As a village leader and SSC leader, she (SSC leader) had high commitment in school and education development (Dauntret school director, interview, 18/05/2015).

These findings indicate that those who provide the budget and who were officially sanctioned by the government were more likely to be able to wield influence in decisionmaking. The interview data also shows that District office of Education (DoE) and commune council participated in the decision in the forming of SSCs. They were invited to the election meetings and other official meetings with schools (DoE deputy director, interview, 22/05/2015). Commune council members and/or leaders were invited to the SSC election process to give technical advice as well (Sung Commune leader, interview, 20/05/2015)

\subsubsection{Collaborating}

This form of participation is concerned with the collaboration of the schools, agencies, businesses, organizations and other groups to share responsibilities for improving schools and education (Epstein, 1995). The study found different education stakeholders participated in education and school development through collaborative works. Each of the stakeholders engaged in education either directly, indirectly, or both. The collaboration activities among schools and communities are summarized in the table below. Table 16 shows four micro-projects which reflect the collaborative works between communities and schools. 
Table 16: Community Collaboration for Education

\begin{tabular}{|c|c|c|}
\hline $\begin{array}{l}\text { Participants in } \\
\text { the projects }\end{array}$ & How participants got involved & $\begin{array}{c}\text { Sources of } \\
\text { information }\end{array}$ \\
\hline \multicolumn{3}{|c|}{$\begin{array}{l}\text { a. Construction projects: Each school had different small construction projects every year for } \\
\text { school and classroom renovation. }\end{array}$} \\
\hline $\begin{array}{l}\text { Teachers, } \\
\text { SSCs, } \\
\text { Local authorities }\end{array}$ & - Conducted fundraising for the constructions & $\begin{array}{l}\text { School } \\
\text { directors and } \\
\text { SSC leaders }\end{array}$ \\
\hline $\begin{array}{l}\text { Parents, } \\
\text { Community } \\
\text { members }\end{array}$ & $\begin{array}{l}\text { - Contributed money, materials and labour for/in the } \\
\text { construction processes. }\end{array}$ & $\begin{array}{l}\text { School } \\
\text { directors, } \\
\text { SSC leaders, } \\
\text { parents }\end{array}$ \\
\hline $\mathrm{NGOs}^{18}$ & $\begin{array}{l}\text { - Provided construction materials such as wood, cements, sand } \\
\text { and so on. }\end{array}$ & $\begin{array}{l}\text { WVC and } \\
\text { KHEN staff }\end{array}$ \\
\hline $\begin{array}{l}\text { Local business- } \\
\text { people }\end{array}$ & - Contributed money and materials for the constructions. & $\begin{array}{l}\text { School } \\
\text { directors }\end{array}$ \\
\hline \multicolumn{3}{|c|}{$\begin{array}{l}\text { b. Education Campaign: All schools conducted education campaign annually to collect all school } \\
\text { aged children }{ }^{19} \text { to enroll in school. School mapping and student census were parts of education } \\
\text { campaign. }\end{array}$} \\
\hline $\begin{array}{l}\text { Teachers, } \\
\text { SSCs, } \\
\text { SCs }\end{array}$ & $\begin{array}{l}\text { - Teachers, SSCs and students worked together to count number } \\
\text { of households and children in the school vicinities. } \\
\text { - Teachers, SSCs and SCs spread education information to } \\
\text { families } \\
\text { - Students, led by teachers and SSCs, matched in the community } \\
\text { to spread education information }\end{array}$ & $\begin{array}{l}\text { School } \\
\text { directors and } \\
\text { SSC leaders }\end{array}$ \\
\hline Local authorities & $\begin{array}{l}\text { - Local authorities guided teachers and students to reach } \\
\text { households in the community } \\
\text { - Local authorities spread education information in the } \\
\text { community and encouraged communities to send their children } \\
\text { to schools }\end{array}$ & $\begin{array}{l}\text { School } \\
\text { directors and } \\
\text { commune } \\
\text { leader }\end{array}$ \\
\hline $\begin{array}{l}\text { NGOs } \\
\text { World Vision } \\
\text { Cambodia and }\end{array}$ & $\begin{array}{l}\text { - WVC conducted training on student census and school } \\
\text { mapping } \\
\text { - Supported stationaries and refreshment to the schools during } \\
\text { school mapping }\end{array}$ & WVC staff \\
\hline \multicolumn{3}{|c|}{$\begin{array}{l}\text { c. Networking for child and women protection: This network was coordinated by the district } \\
\text { authorities aiming for women and child protection against violence }\end{array}$} \\
\hline $\begin{array}{l}\text { Schools, } \\
\text { Health Centers, } \\
\text { Local authorities, } \\
\text { Women and } \\
\text { Child Protection } \\
\text { Committee }\end{array}$ & $\begin{array}{l}\text { - All governmental organizations and NGOs shared roles and } \\
\text { responsibilities in preventing violence against women and } \\
\text { children in the communities. } \\
\text { - All parties reported the issues that happened with children and } \\
\text { women in their communities. }\end{array}$ & $\begin{array}{l}\text { School } \\
\text { directors and } \\
\text { commune } \\
\text { council }\end{array}$ \\
\hline \multicolumn{3}{|c|}{ d. Capacity building: Build capacity of SSCs and teachers } \\
\hline $\begin{array}{l}\text { SSCs, } \\
\text { Teachers }\end{array}$ & $\begin{array}{l}\text { WVC provided capacity building to SSCs on leadership and } \\
\text { management, and teaching methods to teachers } \\
\text { - On leadership and management for SSC and teaching and } \\
\text { learning methods for teachers }\end{array}$ & $\begin{array}{l}\text { WVC } r \text { staff } \\
\text { and school } \\
\text { directors }\end{array}$ \\
\hline
\end{tabular}

${ }^{18}$ World Vision Cambodia and Khmer Education Network

${ }^{19}$ Children who are in their sixth birthday have to enrol in schools (MoEYS, 2015). 
The research findings indicated that, as summarized in Table 16, the most common form of collaborative work between schools and communities was in construction projects for school renovation and environment improvement. The interviews with school directors show that the schools and SSCs conducted fundraising for constructing infrastructure like a kindergarten floor, school fence, improving the school environment and repairing a school building. The four school directors provided similar responses that their schools conducted fundraising to solicit money to complement the budget deficiency for construction of infrastructure. Community members, families and NGOs were found contributing resources in the school development projects (see the findings about resource contribution).

In addition, schools and communities worked together to collect children to enroll in schools. The walls of the each school office had photos of the education campaign with the participation of the parents, communities and local authorities, and maps of the feeder area for students were drawn by teachers and communities (observation). According to interviews with school directors and teachers, drawing the school maps was a collective effort. The schools conducted meetings and formed village networks to identify households and the number of school aged children in the communities (Aphiwat Samlot school director, interview, 11/05/2015).

Next to the government, non-governmental organizations (NGOs) were the most prominent supporters in terms of material contributions for school and education improvements. During the research period, the four schools received support from three NGOs namely WVC (World Vision Cambodia), MJP (Maddox Jolie Pitt) community development organization and KHEN (Khmer Education Network) (Sre Reach school director, interview, 20/05/2015). At the present time, WVC supports training for school directors, teachers, librarians, SSCs and youth clubs in leadership and management, effective teaching and learning, skills to prevent human trafficking and library skills (WVC staff, interview, 21/05/2015).

This research also found that the schools had networks with local authorities to enhance education, and protect women and children against violence and other kinds of abuse. The schools had a joint monthly meeting with the Child and Women Protection Committee 
(CWPC) at the district level ${ }^{20}$. All member stakeholders shared their information and reported in the meeting which was facilitated by the district council (Aphiwat Samlot school director, personal communication, 11/05/2015).

\section{Resource contribution}

Results of the study show that community people contributed their local resources in the school construction projects. The contributions were financial, labour and materials.

Table 17: Type of Community Contribution in the School Development

\begin{tabular}{|l|r|}
\hline \multicolumn{1}{|c|}{ Community contribution $(\mathbf{n = 4 0 )}$} & Percentage \\
\hline Money & $63 \%$ \\
\hline Labor & $20 \%$ \\
\hline Materials & $13 \%$ \\
\hline No contribution & $5 \%$ \\
\hline Total & $100 \%$ \\
\hline
\end{tabular}

\section{Financial contribution}

According to the survey results, financial contribution towards school development was the major form of contribution that communities gave. In response to the question of forms of contribution for school development" in the questionnaire survey, 63\% of participating families selected financial contribution, 20\% selected labour contribution, $13 \%$ selected material contributions and 5\% did not contribute any resources.

The interview with DoE deputy director also demonstrates that the four primary schools had received from their communities a financial contribution of $40 \%$ of the government's annual budget for each school ${ }^{21}$ (interview, 22/05/2015). I observed that the figures given by the DoE deputy director matched with the figures from the four schools. The four

\footnotetext{
${ }^{20}$ School directors were members of the Children and Women Protection Committee at the district level. This committee was formed by the government to protect children and women and to ensure children and women had child rights and human rights (Tasanh commune council member, personal communication, 21/05/2015).

${ }^{21}$ All the four selected schools are state run and receive financial support from the government. However, the government budget was inadequate for school development, and this budget was always late to arrive during the academic year (Sre Reach school director, personal communication, 5/05/2015). The contribution of communities was not compulsory, but it was necessary to complement the budget shortage from the government (Dauntret school director, personal communication, 18/05/2015).
} 
schools had written flipcharts on the walls highlighting the amount of money contributed by the community in the academic year 2014-2015.

Table 18 shows the financial contribution made by communities and families in school and facility construction. The table shows the names of the schools, the amount of money each school received from communities and government in US dollar. The last column shows the comparison of the community contribution against annual government budget.

Table 18: Financial Contribution for School Development (2015)

\begin{tabular}{|l|r|r|r|}
\hline \multicolumn{1}{|c|}{ Schools } & \multicolumn{1}{|c|}{$\begin{array}{c}\text { Financial } \\
\text { Contribution(US\$) }\end{array}$} & $\begin{array}{c}\text { Government } \\
\text { Budget (US\$) }\end{array}$ & $\begin{array}{c}\text { Comparison with } \\
\text { government budget }\end{array}$ \\
\hline Aphiwat Samlot & 438 & 2,668 & $16 \%$ \\
\hline $\begin{array}{l}\text { Dauntret \& its annex } \\
\text { school }\end{array}$ & 1,425 & 2,373 & $60 \%$ \\
\hline Sung 1 & 1,350 & 1,753 & $77 \%$ \\
\hline Sre Reach & 150 & 1,697 & $\mathbf{4 0 \%}$ \\
\hline $\begin{array}{l}\text { Total of the four } \\
\text { schools }\end{array}$ & $\mathbf{3 , 3 6 3}$ & $\mathbf{8 , 4 9 1}$ & \\
\hline
\end{tabular}

According to the table Sung 1 and Dauntret primary school both of which had big construction projects received the highest financial contribution from the communities (DoE deputy director, 22/05/2015). He added that the two schools had big projects such as the animal statues, school fences and community school buildings. These big projects needed additional money from communities and families. For Aphiwat Samlot and Sre Reach there were smaller construction projects but still they raised a fair amount of money to complement their budget shortage.

Another specific reason of discrepancy was the economic hardship of the community. The Sre Reach school director complained that:

Financial contribution is postponed until the next harvest season because the rainfall is late this year which affects farmers' ${ }^{6}$ crops. [.....] we could not request more [money] contributions at a moment. [.....] we cannot do more than that because

${ }^{22}$ The contribution was in Riel currency, but I converted into US dollars with rate of 4,000 riels per US dollar. 
communities are on loan to microfinance institutions (Sre Reach school director, interview, 25/05/2015)

During my field research, I observed that on all the school facilities, there was evidence of financial contribution by the communities. All the four schools bore the names of financial contributors on the school facilities and buildings that had been supported by them. For example, in the photos below, names of charities and communities who contributed money to build the statues were written behind or below the statues (see Figures 16).

Figures 16: Constructions with Communities' Resource Contribution

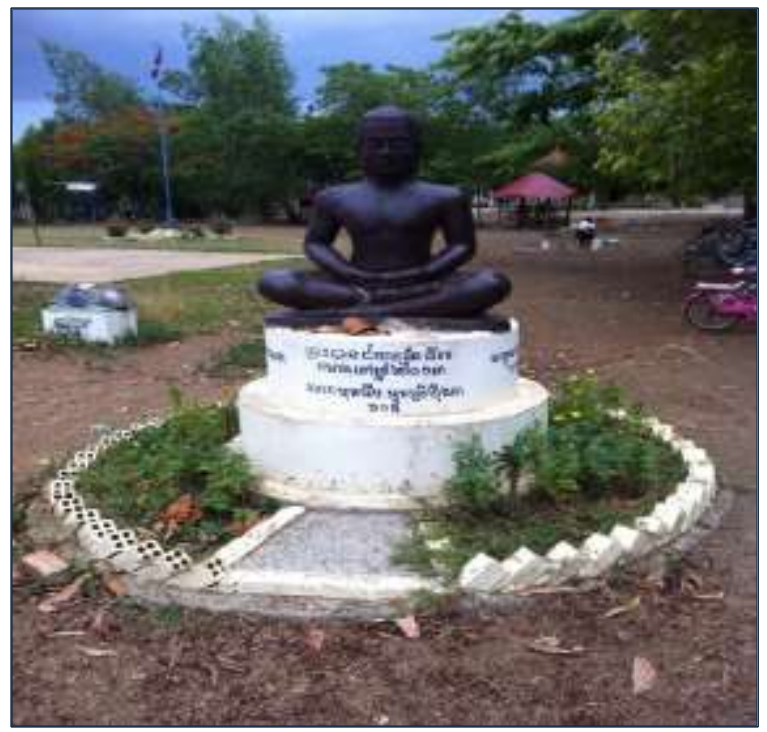

Source: Author, Aphiwat Samlot, 2015

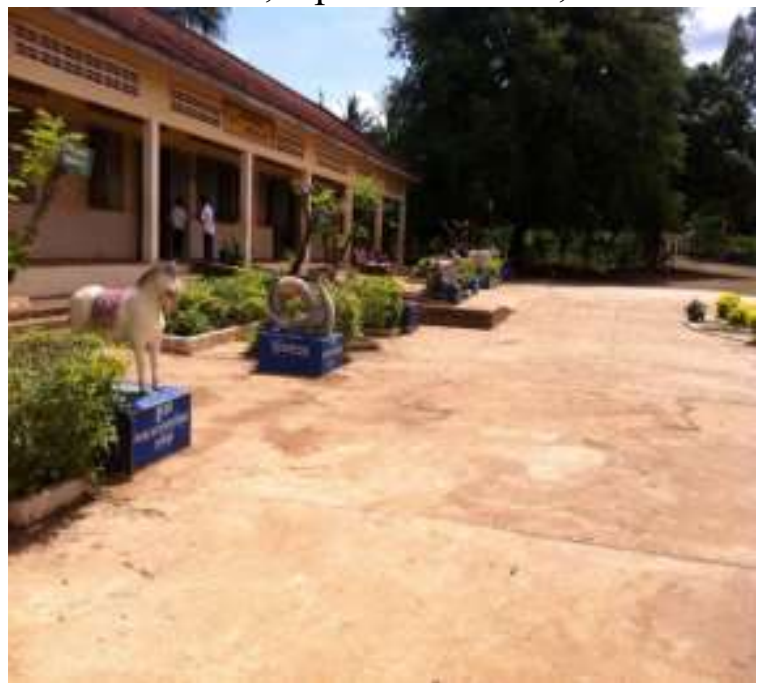

Source: Author, Sre Reach, 2015

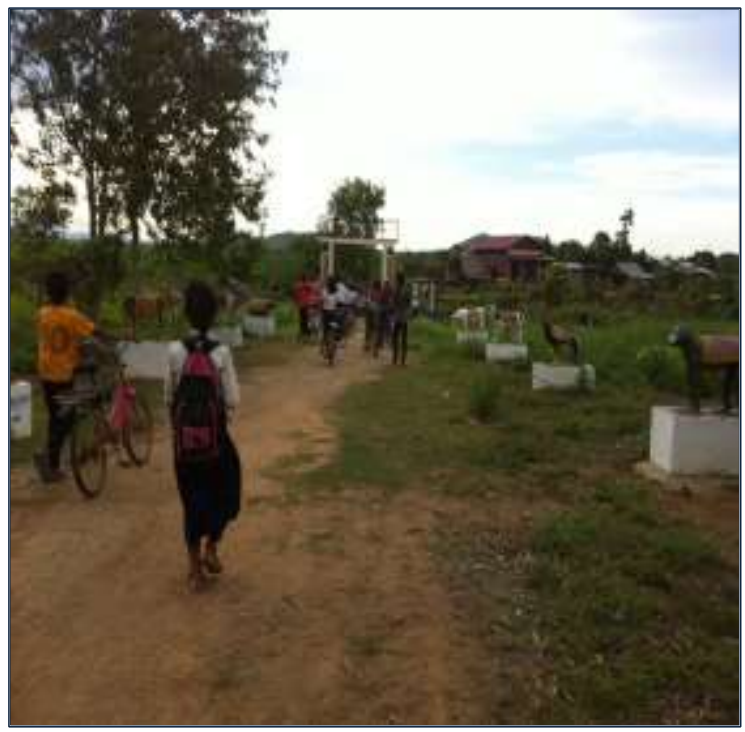

Source: Author, Dauntret, 2015

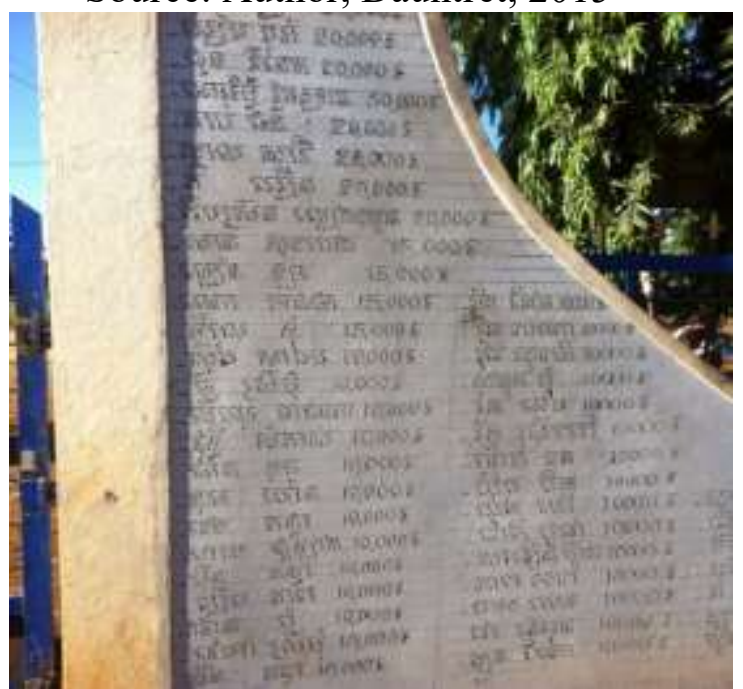

Source: Author, Sung 1, 2015 
According to the interview and survey data, the sources of these financial contributions were teachers, parents, communities, local authorities, Buddhist pagodas, business people, microfinance institutions, banks and international charities. The process of leadership and community mobilization to achieve these contributions are presented in section 5.6.

\section{Material contribution}

The data from the research findings show that some community people were reported contributing materials rather than money, including Buddhist pagodas, business people and NGOs for any school construction projects. They contributed construction materials such as sand, cement and bricks for the construction of school playgrounds and fences:

When the school needs to build school facilities, the local Pagoda contributed cement and bricks for the construction (Dauntret school director, interview, 18/05/2015).

This material contribution was less from parents. The survey result reveals that only $13 \%$ of parents contributed materials on top of their annual financial contribution.

During the research period, WVC and KHEN also contributed construction materials. In Dauntret's annex school, WVC and KHEN provided zinc, wood, cement, sand and bricks for the buildings, concrete playground and school entrance (Dauntret SSC leader, interview, $18 / 05 / 2015)$. On top of that, WVC provided teaching and learning materials such as whiteboards, tables and chairs to the schools (WVC staff, personal communication, 21/05/2015). Figure 17 is the result of collaborative work of the school, community people and NGOs to build an annex school in the community. 


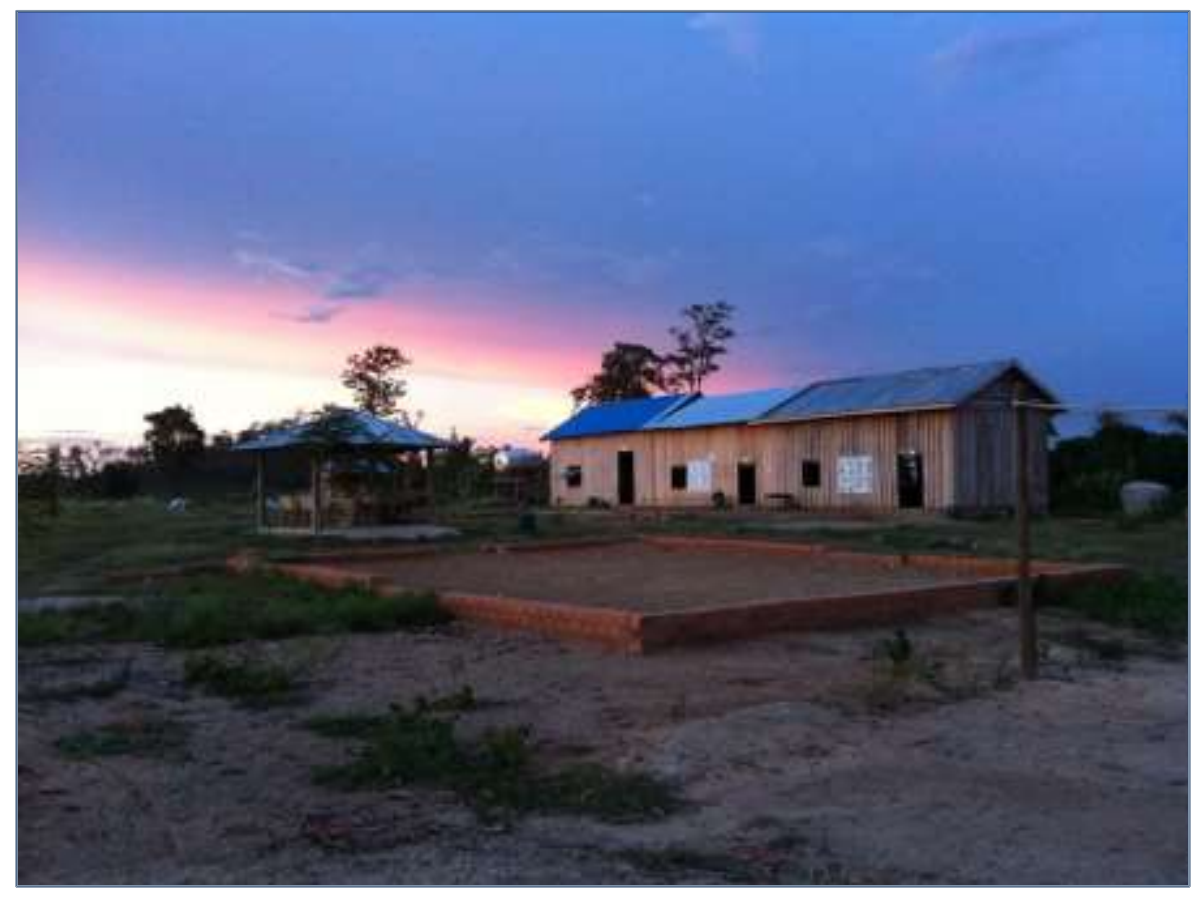

Source: The Author, Dauntret, 2015

Local authorities and communities contributed local materials and construction materials as well. The Sre Reach school director said that:

Communities from the two villages contribute 10 bags of cements, 1 meter cube of sand to construct 40 square meters of concrete school yard (interview, 20/05/2015).

Communities and families were reported as supporting teachers with meals ${ }^{23}$. Teachers who were not from the community were provided accommodation in the schools ${ }^{24}$. According to an interview with a librarian, parents usually provided rice to teachers every month. The Buddhist pagoda also shared the pagoda resources such as rice and food to the teachers who stayed in the school.

\footnotetext{
${ }^{23}$ This is common in Cambodia. This data reflect my personal experience when I was a primary school teacher in a remote school. Students ' parents, communities and Buddhist monks usually gave me food such as uncooked rice, vegetables and fish while I was staying in the community to teach children. This was because communities understood that I had a low monthly paid (my salary was about USD40, but now is about USD100 per month). At the time I was struggling to meet my daily living expenses.

24 The schools had teacher accommodation buildings in the school campus for the whole academic year and teacher returned home during the school holidays.
} 
The pagoda also provided food to the teachers when there is a religious occasion in the pagoda, food left over was usually brought to the teachers who were living in school (Dauntret school director, interview, 18/05/2015)

\section{Labour Contribution}

The data from the questionnaire survey reveals that roughly $18 \%$ of the parents contributed labour in addition to their financial contribution in school development. For example, communities with skills in minor construction came to help to fix school buildings and maintain school facilities (Sre Reach school director, interview, 20/05/2015). Some communities in Dauntret village were mobilized by the village leader to construct the school basement. She (the Dauntret SSC leader) told me that:

In the process of building a new school, we gathered around people in the community to help $[\ldots . .$.$] . We requested them to help filling the land in the school so that the$ compound becomes smooth for the building. All families in the village who had tractors were called in to help in this work (Dauntret SSC leader, interview, 18/05/2015).

In this way, communities spend their time and effort voluntarily to establish the school so that their children could access education.

\subsection{Community Mobilization}

This section presents the mobilization approaches which were used by the selected schools for community participation and education/school development. This section answers the research question How have different schools mobilized the community to participate in education?" The focus of the question is the mobilizing of resources for school development.

\subsubsection{Local Resource Mobilization for School Development}

Local resources from the communities were vital in school and education development and supplemented the government budget for the school operation. According to the interviews with the school directors, the budget from the government was not enough for the school 
development, sometimes the budget was late, or the schools had to follow strict budget guidelines from the MoEYS which made it difficult for the school to respond to the real needs. As such, the schools had to mobilize community resources such as materials, money and labour/services to address these restrictions.

In this research I found no unified approach to community resource mobilization applied in the four schools, but there were some similarities. Each school took an approach that had several steps and processes and these are illustrated through a specific micro-project from each school. Table 19 depicts the different micro-projects which were being carried out by the four schools during the research period.

Table 19: Micro Projects in the Four Selected Schools

\begin{tabular}{|c|c|c|c|}
\hline School & Projects & Activities & Actors \\
\hline \multirow[t]{3}{*}{$\begin{array}{l}\text { Aphiwat } \\
\text { Samlot }\end{array}$} & \multirow{3}{*}{$\begin{array}{l}\text { Kindergarten Renovation } \\
\text { (To construct the floor in } \\
\text { kindergarten) }\end{array}$} & \multirow{3}{*}{$\begin{array}{l}\text { School director, teachers and } \\
\text { SSC leader initiated activities } \\
\text { for fund raising }\end{array}$} & $\begin{array}{l}\text { School } \\
\text { director }\end{array}$ \\
\hline & & & SSC leader \\
\hline & & & Teachers \\
\hline \multirow[t]{3}{*}{ Dauntret } & \multirow{3}{*}{$\begin{array}{l}\text { School environment renovation } \\
\text { (To install concrete statues in } \\
\text { the school compound) }\end{array}$} & \multirow{3}{*}{$\begin{array}{l}\text { SSC leaders conducted } \\
\text { activities for fund raising in } \\
\text { the villages }\end{array}$} & $\begin{array}{l}\text { School } \\
\text { director }\end{array}$ \\
\hline & & & SSC leader \\
\hline & & & Teachers \\
\hline \multirow[t]{3}{*}{ Sung 1} & \multirow{3}{*}{$\begin{array}{l}\text { Building school fence and } \\
\text { installing water system } \\
\text { (To build school fence and } \\
\text { install running water) }\end{array}$} & \multirow{3}{*}{$\begin{array}{l}\text { SSC leaders conducted } \\
\text { activities for fund raising in } \\
\text { the villages }\end{array}$} & $\begin{array}{l}\text { School } \\
\text { director }\end{array}$ \\
\hline & & & SSC leader \\
\hline & & & Teachers \\
\hline \multirow[t]{3}{*}{ Sre Reach } & \multirow{3}{*}{$\begin{array}{l}\text { Repairing roof and constructing } \\
\text { school yard } \\
\text { (To repair the leaking roof and } \\
\text { build concrete school yard) }\end{array}$} & \multirow{3}{*}{$\begin{array}{l}\text { SSC leaders conducted } \\
\text { activities for fund raising in } \\
\text { the villages }\end{array}$} & $\begin{array}{l}\text { School } \\
\text { director }\end{array}$ \\
\hline & & & SSC leader \\
\hline & & & Teachers \\
\hline
\end{tabular}

The evidence shows that in general the schools and SSCs worked collaboratively to mobilize community resources for school development. Both schools and SSCs shared decision-making in planning, roles and responsibilities in carrying out the tasks in the mobilization process.

According to primary data from the interviews, secondary data from the schools and my observation, two broad approaches of community resource mobilization can be identified. In the first approach the school was more active in generating funds and in the second 
approach, SSCs were more active than the schools in mobilizing resources in the community.

In beginning of the process of mobilization, for all the schools, the school director called for a meeting with SSC members and teachers to review the school development plan and start the implementation. Then, the four schools identified target groups of communities to raise funds and a target amount of money to solicit. During the discussion, roles and responsibilities of teachers and SSC members were assigned. In addition, the time frame and target communities for fundraising were discussed. The difference between the approaches occurred in the second layer as shown in Figure $18 \& 19$.

\section{First approach}

Initially, teachers wrote money soliciting letters to parents through students after providing information about the fundraising project. Aphiwat Samlot communicated this information by calling for a meeting with parents and by sending the information through students with the details of budget plans in the letter (see printed fundraising letter in Khmer language in Appendix 13). The meeting aimed at building understanding of parents about the project in order that they contribute their resources to its implementation. The school director believed that communities and parents would participate more when the information was clearly understood.

First, we tell them about general situation of our school, our difficulties, and our needs and tell them about the reasons for what the school wants to have. We told them about the benefit of implementing the project for the children and everyone in the communities. When communities understand about the issues, they agreed to participate and contribute money (Aphiwat Samlot school director, interview, $11 / 05 / 2015)$.

The information about fundraising was spread in the community through the parents, teachers and students. In the first method, school-based fundraising, the school director sent printed letters to students' parents through students. Some parents put money in the envelope and sent it back to the school through their children. Some parents came to the school to contribute money directly. 
Figure 18: The First Model of Community Mobilization (M1)

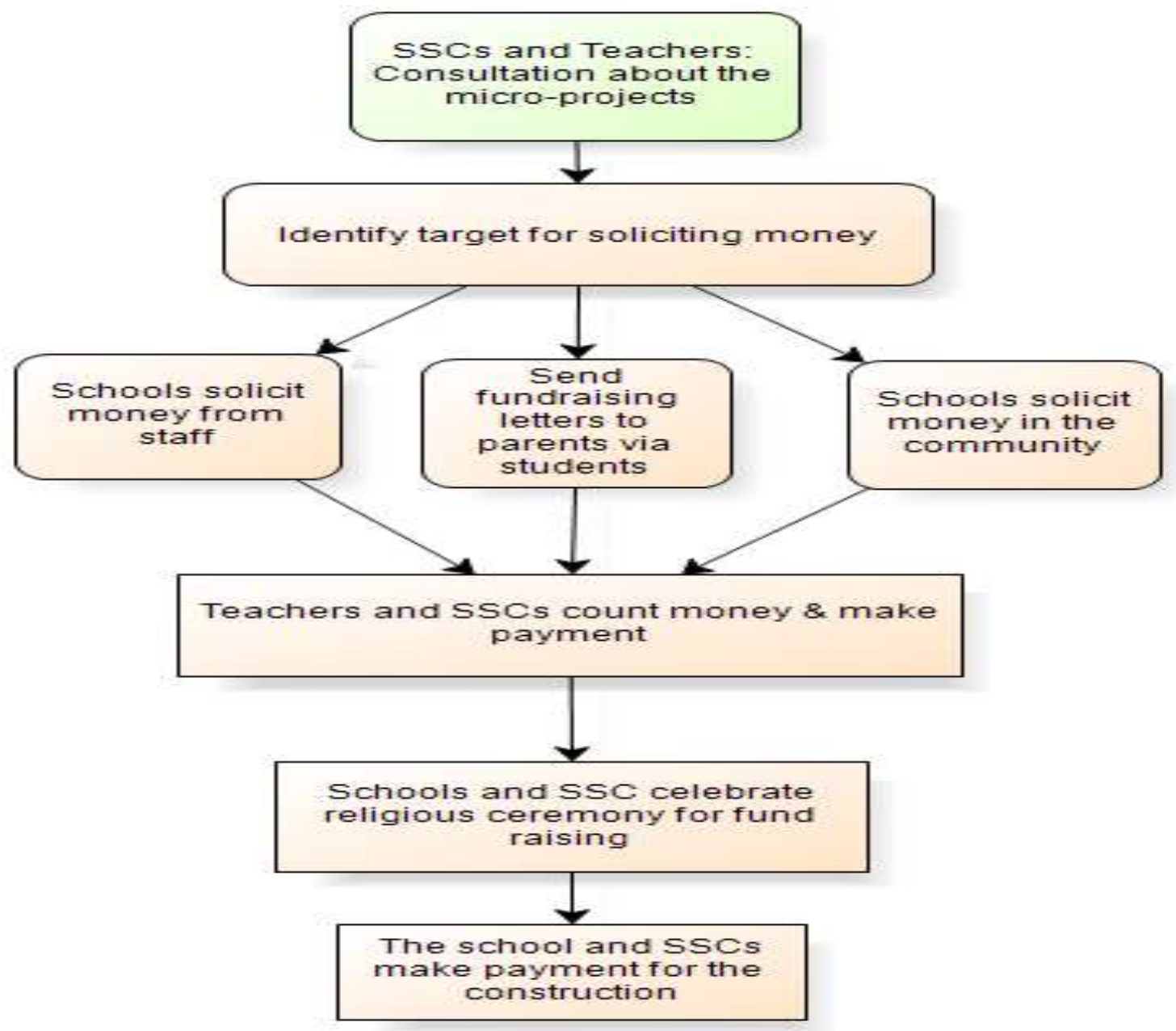

Source: The Author, generated in Nvivo 10

After that, fundraising was carried out by the school director and teachers. They went through the communities to meet the wealthy people, authorities, microfinance institutions, banks and business families to raise funds. Teachers and the school director were asked for more information about the purpose of raising funds because the sponsors were sometimes in doubt about the use of the money. The financial contributors were worried that the money would not be used for the purpose of the school development and they only contributed money after clear explanation was given as to its purpose (Aphiwat Samlot school director, interview, 11/05/2015).

In order to build trust, each sponsor was given a thank you letter'. The letter stated the name of contributor, amount of money, name of receiver and the purpose of the project (see Appendix 14: Letter of contribution in Khmer version). This letter helped contributors to 
feel confident and trust teachers. In addition, teachers promised to write the names of the contributors on the board to indicate that their money was used for the construction. The practice of writing names of sponsors who contributed money served three purposes: to ensure transparency of the budget expenses and to motivate the community to participate in the school as well as to give the businesses a good reputation in the community. The observed evidence of financial contribution is shown in Figure 16.

Once the money was collected (the money was put in the envelope by contributors), teachers, the school director and the SSC came together in the office to open the envelope and counted the money. The names of contributors and the amount of money that they contributed were recorded in a book. Teachers and the SSC leader witnessed this record.

\section{The second approach}

The second approach of community mobilization was used by three primary schools, Dauntret, Sung 1 and Sre Reach primary schools that had village leaders as SSC leaders. In the implementation stage, SSC leaders played roles as village leaders, facilitators and supporters in the communities and schools.

As with the first approach, the process of community mobilization started with planning. As required by MoEYS, the schools developed school development plans with the involvement of SSC members, local authorities, parents, children and teachers. In this planning stage, school directors were the facilitators of the meetings. School directors raised the problems that the schools encountered before proposing for solutions from the meeting. For instance, Sung 1 primary school raised plans to build a school fence, but did not have enough in the budget. Thus, the concerns about budget shortages for the construction project were discussed. Once the plans were approved, teachers and SSCs shared their roles and responsibilities to implement the projects. 
Figure 19: The Second Model of Community Mobilization (M2)

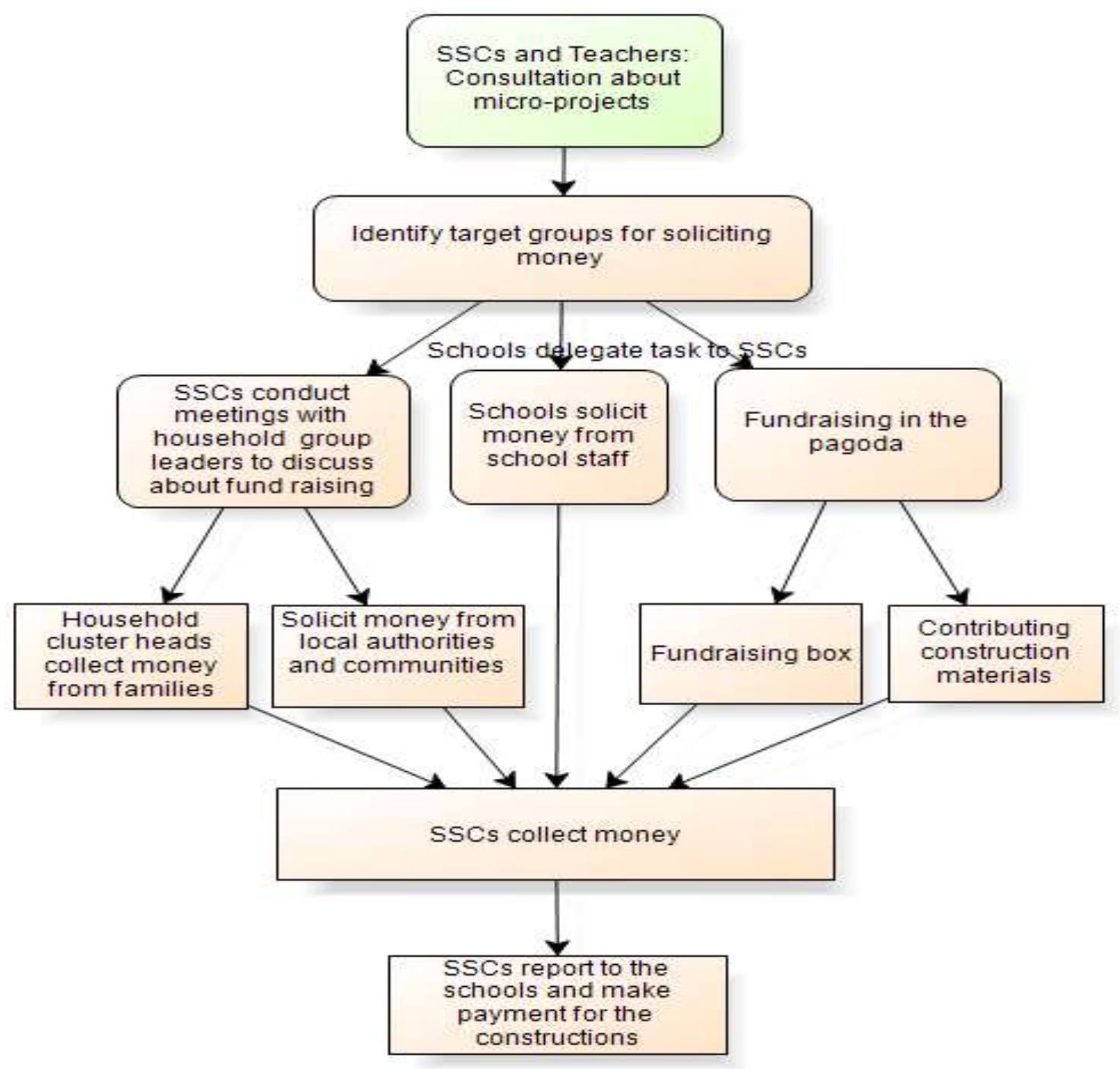

Source: The author, generated from NVivo 10

Following the planning, a series of meetings with parents and communities were conducted to communicate the projects' purposes and benefits for education. In these meetings, the schools built understanding with parents and communities about the benefits of the project.

First, the school shows the school needs, what we are lacking in [...]. So, when we show them the project to do, they understand. When they understand, even though not much but they try to help [...] little by little. First, we show them our plan, second, show actual result. They see the issue, the school's lack of materials, they understand. We invite some communities to join, then, they inform their neighbors 
about the issues. Then, some spend time to participate (Sung 1 school director, interview, 19/05/2015).

According to the interviews with school directors, there was more participation from communities and parents when information about the project was clearly communicated.

When the SSCs received information from the schools about the school development plan, they then conducted meetings to communicate the projects with communities and parents. At this stage, SSC leaders have a role as village leaders in the communities. According to the SSC leader from Dauntret primary school, she conducted meetings with household group leaders after the meetings with teachers and school director to spread information about the project and fund raising activities. Household group leaders take the information to the families in their own villages. The meeting also discussed the amount of money to collect from the parents. They decided to collect a limited amount of money from each family, 5,000 riels which is about US \$1.25. However, this amount was not the upper limit and families were welcome to contribute more. Village leaders and household cluster leaders started their financial contribution in the first meeting in the community, leading by example. Household cluster leaders were responsible for collecting money from their member families.

First, SSC called for voluntary contribution. They do not limit the amount of money. They decide how much to take from each family. The money raised from the family and community was kept by community. The school does not keep the money (Sre Reach school director, interview, 20/05/2015).

Another source of funding was from the Buddhist pagoda. Dauntret primary school is close to a pagoda. The two institutions have a connection and the school director from Dauntret primary school has always asked for financial and material contribution from the pagoda. The school director and SSC leader, who is a Buddhist supporter, initiated putting a fundraising box in the pagoda to raise funds for school development.

We put a fund raising box in the pagoda to raise money for the school development. At some religious occasions [Bon], we can raise 100,000 riels [equal to USD 25]. Because of the good connection with the school, the Buddhist pagoda leaders 
usually contribute money and cement for school renovation (Dauntret SSC, interview, 18/05/2015).

Sung 1 also had Buddhist pagoda support. Even though far from the pagoda, Sung 1 has connections with pagoda because some SSC members are Buddhist clergy people. Sung 1 school director commented that clergy people who were SSC members coordinated fund raising in the pagoda in religious occasions for the schools (interview, 19/05/2015).

Thus, community resource contribution can be summarized having two models; the schoolled resource mobilization (the first model) which was carried out by the schools with consultation and support from SSCs, and delegated-resource mobilization which were responsible by SSCs to solicit money in the community. The first method of mobilization had the teachers to take responsibilities to solicit money from the community and education stakeholders. SSCs only provided advisory support in this method. Meanwhile, there was the delegation to SSCs to conduct fund raising within the second method of community mobilization. SSCs that had village leaders as SSC leaders had influences on the people in the community. SSCs were in charge of collecting money and make payment for the construction. In addition, SSCs had power in the decision-making in school development.

\subsection{Leadership}

According to the data from the interviews, FGDs and observation, the schools and community leaders played leading roles in community participation. Leadership was very important in mobilising community participation in education. In the four selected primary schools, the research found that the leadership of school directors and SSCs (especially SSC leaders) was crucial not only for ensuring the school was well operated, but also for facilitating community participation and mobilizing community resources for school development.

\subsubsection{School Leadership}

The interviews with the school directors show that the four school directors had significant leadership roles in managing the schools. Leadership was shown through transparency, which was the first response by the four school directors when asked about the factors that made communities participate in education. The data from the interviews reveal that the 
schools gained trust from the communities because teachers and school administrators (school directors and admin staff) were transparent in conducting school operations.

Community participation has become better than in the past because we [the school] are transparent. We show the parents what we spent for the money on and how much was spent. For example, when we build Cheyvaraman Seven statue, I show them the result and money that we spent (Aphiwat Samlot school director, interview, $11 / 05 / 2015)$

School administrators were transparent not only with communities, but also with the teachers in the school in planning and using the budget.

[....... when the government budget was granted to the schools, teachers and SSCs conducted discussion meetings about budget allocation and involved SSCs and teachers in all aspects of financial decision making (Sre Reach school director, interview, 20/05/2015).

This finding was backed by the response of a Buddhist monk leader saying that one of the meetings that he had attended was about budget allocation receiving from MoEYS and NGOs (Buddhist monk leader, interview, 18/05/2015).

The interview data with school directors and SSCs show another leadership quality in that school directors and teachers were good at building relationships. School directors made good connections with communities, parents, local authorities and religious institutions. As a result, these groups of communities contributed to the school development. Additionally, the four school directors provided consistent responses that parents trusted the schools because of the teachers' performance and commitment to their teaching (with only a few days of absenteeism). A school director from Sre Reach also agreed with the punctuality of the teachers.

The school directors were flexible enough to substitute teachers who were absent. This regular attendance of the teachers minimized the return home of the students because of absent teachers (Sre Reach teacher, interview, 20/05/2015). 
School directors were aware of the value of networking. The interviews show that school directors as well as their staff built connections with parents, communities, local authorities and NGOs for improve education. For the Aphiwat Samlot school director:

Communities are contributors for school and education improvement. They contributed money, labour and materials for school development and help to protect the school properties (Aphiwat Samlot School director, interview, 11/05/2015).

\subsubsection{SSC Leaders}

The interviews with school directors and SSC leaders reveal that SSC leaders were consistently willing to support their schools. The SSC leaders had an intrinsic motivation to help their school. Even though they were unpaid, they were enthusiastic about spending their time to help the schools because they perceived that helping the schools would have long term impacts in their communities. The children in the next generation would then also develop their communities.

SSC leaders were influential in the schools and in the communities. Three out of four SSC leaders were also village leaders. SSCs were responsive and focused on the school development. One SSC leader was a former school director, so he also had influence in his community even though his level of power was not equal to that of the village leaders.

$[\ldots \ldots \ldots . .$.$] If the school has problems, we just tell her [the SSC leader] then she informs$ the community members to help. That point is very good. When we inform her, she help right away. She is always helpful. One day, she contacted charities outside the school community to build Buddhist statues. The statues turn up surprisingly in the schools as the school was not informed (Dauntret school director, interview, 18/05/2015).

SSC leaders were observed using their positional power as village leaders to influence their community. According to the interview with school directors and SSC leaders, as local authorities, the village leaders, who are also SSC leaders, spread education information in their villages, and tell parents to send their children to schools and encourage families to support children learning at home. Village leaders were reported to be effective in resource mobilization. 
[...] we selected and voted for the one who has authority roles such as village leader or deputy village leader to be an SSC leader [....] if we have local authorities as leader in SSC, he has power of mouth. For example, when we make plans to raise funds, he is influential and can raise funds from communities for the school [........] (Sre Reach school director, interview, 25/05/2015)

This section can be concluded that SSCs and school administrators were the driving force in bringing community people and parents together to participate in children's education.

\subsection{Motivation of Participation}

The question about which factors motivated communities to participate in education received different answers from research respondents. They are summarized in Table 20 below:

Table 20: Motivation Factors of Participation in Education

\begin{tabular}{|c|c|}
\hline Respondents & Motivation Factors \\
\hline $\begin{array}{l}\text { Teachers and school } \\
\text { directors }\end{array}$ & - $\quad$ Being fascinated in helping children‘s learning \\
\hline SSC leaders & $\begin{array}{l}\text { - Want to see the school improve. } \\
\text { - Want to see children become good citizens and good leaders in } \\
\text { the communities. } \\
\text { - } \quad \text { Good understanding between schools and SSCs }\end{array}$ \\
\hline $\begin{array}{l}\text { Parents } \\
\text { (FGDs with parents and } \\
\text { questionnaire survey) }\end{array}$ & $\begin{array}{l}\text { - Want children to have knowledge } \\
\text { - Want to help the school development } \\
\text { - } \quad \text { Some children who graduated from the communities were able to } \\
\text { get good jobs which have an effect on parents' expectations. } \\
\text { - } \begin{array}{l}\text { Punctuality of teachers in their daily teaching created trust with } \\
\text { communities }\end{array}\end{array}$ \\
\hline Authorities & $\begin{array}{ll}\text { - } & \text { Driven by policy of the local government to support education. } \\
\text { - } & \text { Want to build the next generation }\end{array}$ \\
\hline $\begin{array}{l}\text { Communities } \\
\text { (KII with a monk leader) }\end{array}$ & $\begin{array}{l}\text { - Interested in seeing children have knowledge so that they can } \\
\text { contribute to community development. }\end{array}$ \\
\hline
\end{tabular}

Table 20 shows that different groups within the communities had different factors that brought them together to participate in education. These factors could be categorized into two groups, intrinsic and extrinsic motivations. Teachers and local authorities had external factors such as their roles and responsibilities which were assigned by the government. However, teachers and local authorities also demonstrated personal compassion for helping 
children learn. Parents, SSCs and communities reported that they were passionate to help children to get a good education as they thought the investment in this education would result in the development of their community in the future.

\subsection{Obstacles to Participation}

The question about the obstacles to participation and getting people to participate also had diverse answers from research participants. Table 21 depicts the different obstacles as described by each stakeholder.

Table 21: Obstacles of Participation in Education

\begin{tabular}{|c|c|}
\hline Respondents & Obstacles \\
\hline $\begin{array}{l}\text { Teachers and } \\
\text { school director }\end{array}$ & $\begin{array}{l}\text { - It was hard to get parents and communities who lived far from the school } \\
\text { to participate in the school (problems with communication) } \\
\text { - Poor living condition of the parents causes children to have regular } \\
\text { absences and leads to them dropping out of school. } \\
\text { - Parents prioritized their livelihood before study even though they } \\
\text { understood that education was important for their children. } \\
\text { - Hard to contact parents because of poor network in the area and bad road } \\
\text { conditions to reach students' homes. } \\
\text { - Families migrate frequently (parents usually bring along their children } \\
\text { when they move) } \\
\text { Difficult to communicate through the student study record for illiterate } \\
\text { parents. }\end{array}$ \\
\hline SSC le & $\begin{array}{l}\text { - No external motivation from local authorities and DoE even though they } \\
\text { were fascinated by education. } \\
\text { - } \quad \text { Prioritized personal work over the school needs } \\
\text { - } \quad \text { Only SSC leaders had frequent participation in the schools. }\end{array}$ \\
\hline Parents & $\begin{array}{l}\text { - Only } 35 \% \text { of parents responded -bsy", } 15 \% \text { of parents responded -pon } \\
\text { living condition and far distance from school" } \\
\text { - Some parents were illiterate making it difficult to communicate through } \\
\text { writing }\end{array}$ \\
\hline $\begin{array}{l}\text { Authorities } \\
\text { (commune } \\
\text { village } \\
\text { authorities) }\end{array}$ & $\begin{array}{ll}\text { - } & \text { Busy at work } \\
\text { - } & \text { Not prioritizing education } \\
\text { - } & \text { Prioritized socio-economic development in the community than education }\end{array}$ \\
\hline Communities & $\begin{array}{l}\text { - Communities could not contribute for school development because they } \\
\text { contributed their money in other sector development such as health, } \\
\text { agriculture and road construction. }\end{array}$ \\
\hline
\end{tabular}

Common responses related to barriers in communication, being too busy with work, some unwillingness on the part of parents to participate, poor living conditions of the parents, 
less motivation from the local authorities to carry out voluntary works (SSCs) and less understanding of the communities on the importance of their participation in education.

The table shows some interesting contradictions. The participants highlighted these difficulties because they had higher expectations about their participation and the participation of the community in education than they were able to meet. For instance, teachers expected to use student study records to communicate with the parents, but parents were unable to read and write which caused ineffective communication. In another example, local authorities expected to voluntarily participate more frequently in the education, but they were also busy with their jobs. Another possible reason for some of these discrepancies is that the participants tended to show their positive attitudes towards their participation in education in interviews, but these challenges revealed limits to their actual participation.

\subsection{Conclusion}

To summarize, the research found a range of education stakeholders in the research area who had different perspectives on community participation in education. Most of them emphasized the contribution of money, materials and labour in school development as an important part of the community participation.

The analysis of the data responded to the central questions regarding the types and processes of community participation in education that are currently occurring in rural schools in Cambodia. The types of participation mapped well on to Epstein's involvement frameworks' which defines six types of involvement: parenting, volunteering, communicating, learning at home, decision making and collaborating with communities. In addition, another form of participation was community contribution which commonly occurred in the research area. This contribution included money, materials and labour for school development, and it was categorized as collaborating with the community.

As the contribution of money and materials was common, approaches to community resource mobilization for school development were explored. Two approaches to resource mobilization were found within the four schools. The first approach concerned the active role of the school in soliciting money for the school development, while the second 
approach was more concerned with the empowering of the SSC leader in generating funds within the communities.

The participation of the communities (in different ways) was influenced by the leadership quality of the schools and SSCs. These two partners appeared to be the driving force behind such participations and contributions.

The research found both intrinsic and extrinsic motivations to be important in accelerating the participation of the community in education. However, some barriers of participation were found such as the unwillingness of people to participate, a lack of time or resources, poor means of communication and the limited understanding on the value of participation in education among communities. The next chapter presents the discussions of the research findings. It seeks to respond to the research question with regards to the degree of community participation in education adopting Bray's degrees of community participation framework. 


\section{CHAPTER 6}

\section{DEGREES OF COMMUNITY PARTICIPATION IN EDUCTION}

\subsection{Introduction}

This study explores the nature and level of community participation in education in remote schools in Cambodia. The focus of the study was the nature of the participation of local people in education in the four primary schools in a remote district in Cambodia. To investigate this participation, a mixed method approach was used to explore the attitudes and behaviors of families and communities in four remote schools. Epstein's participation framework and Bray's degrees of community participation were used as analytical tools for this research. The result of the study is expected to contribute to the body of literature on community participation in education in the remote schools in a developing country. This chapter discusses the literature and the research findings.

\subsection{Degrees of Community Participation}

Analysis from this study showed a noticeable discrepancy among communities, parents and education stakeholders with regard to their participation in education. Their participation is spread over the various levels of participation described in Bray's degrees of community participation (2000) which is shown in Table 22. The six types of community participation are situated into different levels according to the nature of their participation. 
Table 22: Types and Degrees of Community Participation in Education in the four Primary Schools in Samlot District

\begin{tabular}{|c|c|c|c|c|c|c|c|}
\hline \multirow{2}{*}{$\begin{array}{l}\text { Forms of } \\
\text { participation }\end{array}$} & \multicolumn{6}{|l|}{$\begin{array}{l}\text { Pseudo } \\
\text { Participation }\end{array}$} & \multirow{2}{*}{\begin{tabular}{|l}
$\begin{array}{r}\text { Genuine } \\
\text { participation }\end{array}$ \\
$\begin{array}{l}\text { Real } \\
\text { powers (7) }\end{array}$
\end{tabular}} \\
\hline & Use of service (1) & $\begin{array}{c}\text { Resources } \\
\text { Contribution } \\
\text { (2) }\end{array}$ & $\begin{array}{l}\text { Attendance at } \\
\text { meetings (3) }\end{array}$ & $\begin{array}{c}\text { Consultation } \\
\text { (4) }\end{array}$ & $\begin{array}{c}\text { Involvement in } \\
\text { delivery (5) }\end{array}$ & $\begin{array}{l}\text { Delegated } \\
\text { powers (6) }\end{array}$ & \\
\hline Parenting & $\begin{array}{l}\text { Sent children to } \\
\text { school and } \\
\text { assisted children's } \\
\text { daily schooling }\end{array}$ & $\mathrm{n} / \mathrm{a}$ & $\begin{array}{l}\text { Attended meetings } \\
\text { and school events }\end{array}$ & $\begin{array}{l}\text { Consulted with } \\
\text { teachers about their } \\
\text { children's learning } \\
\text { progress }\end{array}$ & $\mathrm{n} / \mathrm{a}$ & $\mathrm{n} / \mathrm{a}$ & $\mathrm{n} / \mathrm{a}$ \\
\hline $\begin{array}{l}\text { Learning at } \\
\text { home }\end{array}$ & $\begin{array}{l}\text { Encouraged } \\
\text { children, taught } \\
\text { children at home } \\
\text { and checked } \\
\text { homework }\end{array}$ & $\mathrm{n} / \mathrm{a}$ & $\begin{array}{l}\text { Attended meetings } \\
\text { when invited by } \\
\text { teachers }\end{array}$ & $\begin{array}{l}\text { Consulted with } \\
\text { teacher about how to } \\
\text { help children's } \\
\text { learning at home }\end{array}$ & $\mathrm{n} / \mathrm{a}$ & $\mathrm{n} / \mathrm{a}$ & $\mathrm{n} / \mathrm{a}$ \\
\hline Communicating & $\mathrm{n} / \mathrm{a}$ & $\mathrm{n} / \mathrm{a}$ & $\begin{array}{l}\text { Received information } \\
\text { in the meetings and } \\
\text { school events }\end{array}$ & $\begin{array}{l}\text { Teacher and parents } \\
\text { communicated about } \\
\text { children's learning in } \\
\text { various ways }\end{array}$ & $\begin{array}{l}\text { Communities and } \\
\text { students shared } \\
\text { information in the } \\
\text { wider community }\end{array}$ & $\mathrm{n} / \mathrm{a}$ & $\mathrm{n} / \mathrm{a}$ \\
\hline Volunteering & $\mathrm{n} / \mathrm{a}$ & $\begin{array}{l}\text { Communities } \\
\text { voluntarily } \\
\text { spent time to } \\
\text { look after } \\
\text { schools }\end{array}$ & $\begin{array}{l}\text { SSCs, parents, local } \\
\text { authorities attended } \\
\text { the meetings and } \\
\text { school events }\end{array}$ & $\begin{array}{l}\text { Consultations among } \\
\text { SSCs, local } \\
\text { authorities for } \\
\text { education/school } \\
\text { development }\end{array}$ & $\begin{array}{l}\text { Education campaign, } \\
\text { network for child } \\
\text { protection, trainings }\end{array}$ & $\mathrm{n} / \mathrm{a}$ & $\mathrm{n} / \mathrm{a}$ \\
\hline Decision-making & $\mathrm{n} / \mathrm{a}$ & $\mathrm{n} / \mathrm{a}$ & $\begin{array}{l}\text { SSCs attended the } \\
\text { meetings to establish } \\
\text { annual school } \\
\text { development plan }\end{array}$ & $\begin{array}{l}\text { SSC conducted fund } \\
\text { raising; DoE and } \\
\text { local authorities gave } \\
\text { technical advices }\end{array}$ & $\mathrm{n} / \mathrm{a}$ & $\begin{array}{l}\text { Decision } \\
\text { making in } \\
\text { planning, fund } \\
\text { raising, } \\
\text { construction, }\end{array}$ & $\mathrm{n} / \mathrm{a}$ \\
\hline Collaborating & $\mathrm{n} / \mathrm{a}$ & $\begin{array}{l}\text { Contributed } \\
\text { resources for } \\
\text { school } \\
\text { infrastructure }\end{array}$ & $\begin{array}{l}\text { SSCs and parents } \\
\text { attended the meeting } \\
\text { to get information } \\
\text { about school micro } \\
\text { projects }\end{array}$ & $\begin{array}{l}\text { SSCs consulted with } \\
\text { the schools about } \\
\text { how to do fund } \\
\text { raising }\end{array}$ & $\begin{array}{l}\text { Teachers and SSCs } \\
\text { conducted fund } \\
\text { raising together }\end{array}$ & $\begin{array}{l}\text { Networking for } \\
\text { child protection; } \\
\text { SSCs raised } \\
\text { funds }\end{array}$ & $\mathrm{n} / \mathrm{a}$ \\
\hline
\end{tabular}


According to this table, _parenting' and _learning at home' are the lowest degree of participation, while communicating' and =volunteering' reach service delivery and =collaborating with community ${ }^{\star}$ and _decision making' involves delegated power. These forms of participation are further explained below.

Parenting: Results of the study show that parental involvement in children's learning varied from home to school. The evidence was shown through the activities of sending their children to schools and supporting children daily schooling such as preparing their children for school with learning materials and appropriate dressing. Parents were also reported to approach teachers to get information about their children's learning progress. They consulted with their children's classroom teachers about their children's learning. These activities are counted as parenting because parents created opportunities for children to have knowledge through education (Bornstein, 2005; Epstein, 1995). The involvement demonstrates that parents cared for the future of their children. They responded to the government policy which suggests parents send their children to school. It also reflects parents' understandings of the value of education.

To assist parents with parenting, the schools were found to have encouraged parents to send their children to schools and advised parents to provide learning support to the children. Their suggestions indicated that teachers had the intention to support parents with regards to parenting. Teachers appear to understand the importance of the participation of the parental involvement in children's learning. However, no specific parenting skills were given to parents and caretakers, except for the consultations and informal discussions between parents and teachers about children's learning progress and challenges of children's learning. This indicates that the parenting knowledge, which is important to enhancing children's learning (Epstein, 1995), was not the focus of the schools. This might be because of no attention being given by the government to these skills.

Learning at home: Parents were found assisting their children studying at home after class. Participating parents were reported supporting their children at home with their studies but only a minority of them helped in teaching and checking their children's books, and most of the parents only provided encouragement and told the children to study before bed. The research findings were consistent with Nguon (2012) that educated parents tended to get 
much more involved in their children's learning than their counterparts. Poorer families had less involvement because they were busy working. Some educated parents came to the schools to consult with the teacher on their teaching method so that they could help their children's learning at home. In order to get parents more involved in supporting their children's learning at home, teachers motivated parents to come to talk with them about their children's learning progress. Teachers provided advice on how to assist their children.

From these findings it can be assumed that parents attempted to get involved in their children's learning, but this was under-utilised because of the limited abilities of the parents. The research findings show that most parents had difficulties in reading and writing which are barriers for them in supporting their children. In addition, parents appeared to have a dependent perception on teachers to help their children's learning. To assist parents, teachers seemed have the intention to get involved in children's learning through suggesting to the parents to come and talk about their children's learning. Buddhist monks were also seen as helpful in encouraging parents to focus on their children's learning. They advised parents in religious ceremonies to help their children's learning. Despite the advice, the lack of focus of the parents in children's learning is a sign of inequality among children (Sachs, 2015). According to Sachs, this could have a long-term impact on the inequality among the next generation.

The degrees of participation of the parents in these two forms, parenting and learning at home, were found to be moderate influences. The parents were involved in discussions and informal talks without any evidence of taking part in actual decision-making. These forms of participation, therefore, are undoubtedly at the consultation level (level four of degrees of participation). Consultation, according to Bray (2000), is a degree to which the participants get involved in sharing information and discussing education programs and their children's learning progress.

Communicating: It is evident that community people and parents participated in education through communicating education information. The schools and parents communicated children's learning through various aspects such as meetings, written and verbal communication tools. Non-parents, local authorities and other stakeholders received updated education information through meetings, letters and phone calls. Receiving the 
education information, communities and parents spread the information in their community so that community members understood the value of education and got involved in children's learning. These processes imply that parents and community members got involved in delivering and interpreting education information to a wider community. In addition, local authorities and SSCs were found using several means of communication such as meetings, phone calls and school visits.

The schools' diversified means of communication to reach parents and community members was evident with teachers using appropriate channels of communication with even the most remote families to follow up children's learning. The study found that the official written communication tools were challenging for some parents and community members because they had difficulties in reading and writing. It was hard to create a twoway communication system which resulted in less effective communication as suggested by Epstein $(1995,2004)$. It was fortunate then, that the schools had the community, parents and SSCs to assist spreading information to the wider community, especially those with lower levels of literacy.

These findings show that the written communication tools which were used officially to communicate children's learning performance between schools and parents tended to be not always appropriate and sometimes ineffective due to the ability to read and write of the parents. The other options that could be applied such as meetings, home visits and phone calls require an added commitment of the teachers and the parents themselves.

Volunteering: The study found two groups in each school that consisted of volunteers. School Support Committee (SSCs) which were community representatives in the schools had mixed members such as local authorities, retired teachers, Buddhist monks, clergy people and parents. These people participated in the committee voluntarily. SSCs participated in the meetings with teachers to develop school development plan and discuss about school and education development; conducted fundraising for school development; and looking after school properties. Students through Student Council (SCs) assisted the schools in environment, learning, school safety and other administrative works in the schools. In addition, in the research area, the study found active Youth Club (YCs) supported by World Vision Cambodia (WVC) to provided awareness raising on child 
protection, domestic violence and hygiene and sanitation in the community and schools. Community members, families and local authorities were volunteers who participated in the school meetings and some schools events when they were invited. The study did not find any voluntary activities related to curriculum development, as this area seemed to be left to the teachers.

These findings demonstrate that community people had a strong commitment to helping to improve schools and education. Even if the schools did not provide training to the volunteer groups, the schools received the assistant from NGOs to build the capacity of teachers and SSCs as well as Youth Clubs.

The research findings above indicate that community people got involved in education through communicating education information and voluntary work to assist the schools. Despite no evidence of unequal power relations between the schools and community people, these community people were reported to be active in spreading education information. The nature of the involvement of the community and parents in education above matched the fifth degree of participation (Bray, 2000) which has a tendency of becoming between the schools and community as described by Arnstein (1969).

Participation in decision-making is the involvement of parents and community members in school decisions, governance, and advocacy activities for school and education development through the school committee (Epstein, 1992, 1995, 2006; Epstein \& Salinas, 2004). It is evident from the findings that SSCs had various rights and a degree of power in the decision-making process. Schools and SSCs were observed sharing power in decisionmaking. SSCs were normally invited to participate in establishing school development plans and the budget plans, and in monitoring and evaluating education programs and school development projects. The schools worked in partnership with SSCs for education and school development where power was distributed. Arnstein (1969) suggests that: power is in fact redistributed through negotiation between citizens and power holders" (p.221). It became clear that genuine participation lies where power is distributed among participants, reflecting the work of Bray (2001).

Collaborating: This form of participation is concerned with the collaboration of the schools, agencies, businesses, organizations and other groups to share responsibility for 
improving schools and education (Epstein, 1992, 1995, 2006). Collaborative activities of the community and parents were reported to take place at different levels ranking from = resource contribution' to _delegated power'. The community, parents, students, NGOs, Buddhist monks, teachers and local authorities were reported as working collaboratively on school construction, collecting children to go to school, networking for child protection and capacity building. In this case, SSCs were reported to be a working partner in fundraising for school development. Community resources were mobilized. This participation indicates that community and teachers respected each other in decision-making. Thus, their collaborative participation can be assumed as reaching Bray's level of delegated power'.

The participation of community in decision-making and collaborating forms (delegated power) is close to genuine participation. According to Bray (2001), genuine participation is the participation in which all participants have equal rights in decision making (it is the partnership rung in Arnstein 1969).

The degrees of community participation in education can be summarized in the following figure.

Figure 20: Degrees of Participation in Education in Four Schools of Samlot District

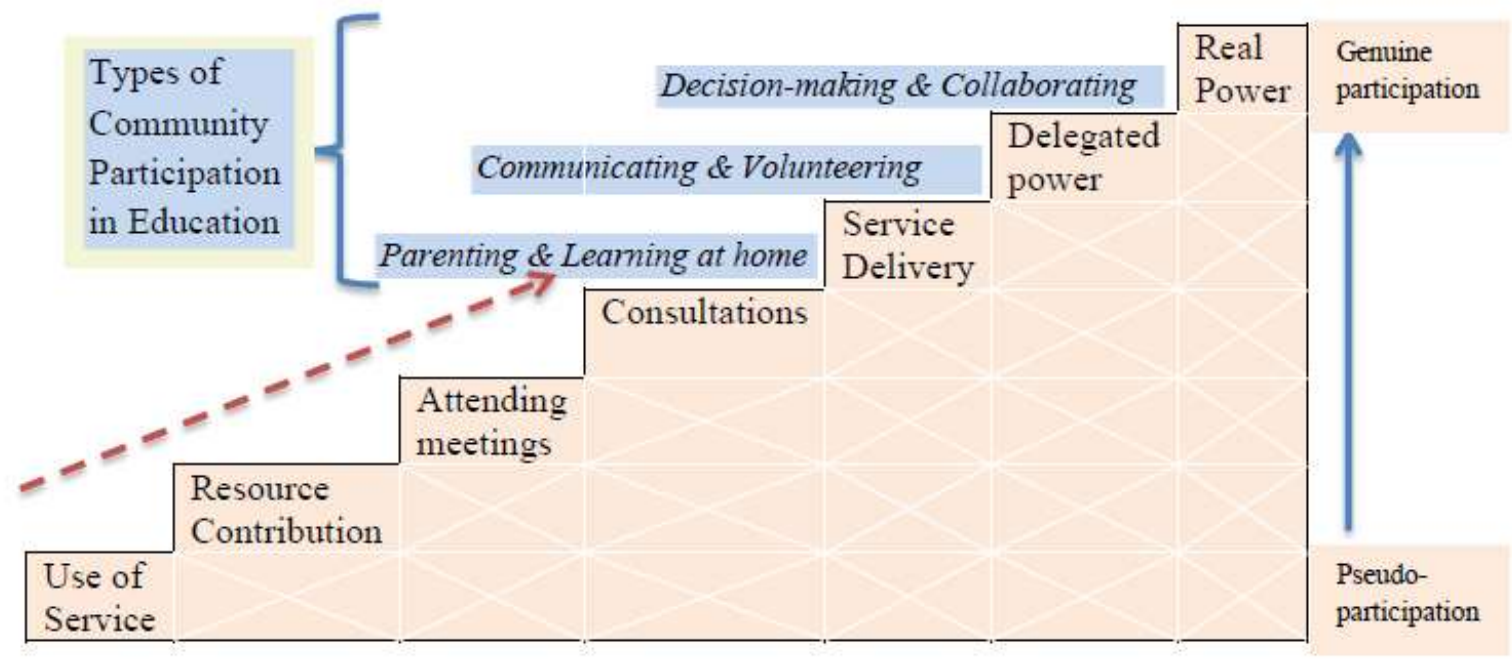

\subsection{Community Participation Policy and Practices}

The fifth dimension of the policy of Child Friendly Schools (CFS) has as an outcome, to promote the relationship and participation between/of schools and communities in order 
that this relationship becomes a collective resource for school/education development (MoEYS, 2007). The school Support Committee (SSCs) framework was developed to include community representatives in the schools. The basic idea of this framework was to enhance ownership of the community within the schools because the schools are community assets where community involvement is necessary (MoEY, 2014). According to this policy, the Cambodian government attempts to work in tandem with communities to improve education. The guideline suggests mixed components of SSC to extend community representativeness. The research findings to a certain extent reflect that this community participation policy is working effectively.

The structure of SSCs of the four schools shows strong power and the ability of community resource mobilization. According to the study, the four remote primary schools had village leaders or retired teachers as leaders of the committee. This included Buddhist monks, the elderly and parents as well as commune authorities who were also on the board of management of the SSC. This collective, mixed component committee enables the SSCs to gain more power in their decision-making in education development as DeRienzo (2008) has suggested that power appears when people are collective. In addition, the inclusion of such a mixed group in the committee increases the ability of the SSCs towards pooling resources from a wider section of the community (De Beer, 2006; Rose, 2003). According to Pellini (2007), local authorities and the elderly in Cambodian society are highly respected so by including them in the committees they increase the $\mathrm{SSCs}^{\text {‘ }}$ power.

SSCs were found to be active in most aspects of participation and especially in the decision making in school development plans. The most commonly observed tasks that the study found were community resource mobilization. According to the research findings, SSCs helped the schools in sourcing resources from community members for school construction and school renovation activities. Community people could indirectly participate in education through their resource contribution through SSCs.

In spite of this, the SSCs structure could be more inclusive of other governmental departments and agents such as health centres and district agriculture offices, educated families or retired better off people so they too can influence the participation practice. A greater, more multi-sectoral committee could enhance the ability of SSCs to support 
school/education development not only through mobilizing resources, but also promoting the culture of sharing and participation within the community.

\subsection{Traditional Practices of Community Participation}

The results of the study show that the most common form of participation in education was resource contribution. Community people and families contributed their available resources such as money, materials and labour in school renovations and environment improvements when requested by the schools. Their contributions were shown to be important for school development as it could respond to the real needs of the schools, unlike the government budget which could not respond so quickly. The practices reported in the study reflect the contention of Rose (2003) that community contribution is desirable when public resources are insufficient.

This finding reflects the social norms and culture of the local community towards the participation in education. This resource contribution practice has been reportedly practiced in Cambodian society in the past. According to Pellini (2007) and Clayton (2000), after the decolonization period and the destruction by civil war in the $1980 \mathrm{~s}$, the government of Cambodia called for resource contribution for schools ${ }^{6}$ construction for children's learning. Community resources were significantly complementary to the challenging budget shortage of the government for education development. This practice has been passed on to the next generation as presented in my study. In line with the findings of Save the Children Cambodia (2015), this study shows that community people become participatory when called for contributions. This trend of participation practice may stay unchanged unless community people change their perception about what contribution and participation entails.

The practice of resource contribution influences the ways local people construct their knowledge about community participation in education. According to the research findings, community people perceived participation in education as resource contribution in school development more than their involvement in their children's learning. There is some supporting evidence that the schools mobilized community people to provide resource contributions for physical infrastructure and environment improvement. The perception could be influenced by the government policies and guidelines and the policy 
interpretation. According to the SSC's guideline, the focus of participation is resource contribution, which may mean that it seems more important and is prioritized over other forms of participation.

It is true that a good school environment and facilities could have emotionally positive impacts on children and attract children to schools (Bernstein \& Brannen, 1996; Hughes, 1996). It can be substantially beneficial in enhancing children's learning outcome when it is a necessity and appropriately reflects the real situations and needs of the schools and the availability of the resources. For instance, kindergarten renovation is very important and beneficial for children's learning as little children should have appropriate classrooms to learn in and they are likely to come to school regularly if the environment is a positive one. Nevertheless, in my opinion, some school facility construction tends to be wasteful such as the animal statues and Buddha statues even though these statues were educative for children. They did not reflect the real needs of the schools. In this example, the community of people suffer economic hardship and $45 \%$ of the community in the study area were poor (RGC, 2012). In addition, according to the research findings, farmers encountered late rainfall in the current year which affected their crops. Consequently, this affected the incomes of the farmers. On top of their hardship, communities were called on for multisectoral development projects including health, agriculture and education. Thus, there are many demands on farmers who are already struggling financially.

Even though resource contribution was of importance for school development, in my opinion the practice tended to narrow the concept of participation. In addition, it was likely to affect the behaviour of community people towards their participation. This practice should be changed through changing the perception of teachers and the community. The schools should consider the capacity of the school and community when proposing school development projects. To optimize the community resources, the schools should run development projects that contextually benefit children's learning. The school administrators should shift their focus to the participation for children's learning, although attention to collecting children to schools should still be made. More attention could go on increasing numeracy and literacy skills rather than certain structures or facilities. 


\subsection{Schools and SSCs for Participation}

On top of the six types of community participation in education, the study investigated the leading roles of the schools and community to mobilize community participation. The schools were found to possess leadership characteristics that entrusted the communities to get involved. The study found the schools were transparent in the school administration. The schools presented their plans to the community members, and the money that community members contributed was displayed on the school facilities. School staff were reported as having good relationships and being good network builders. They built connections with community members and encouraged community people to get involved in children's education.

SSCs were reported as having positive leadership roles in supporting education programs in the schools. More specifically, SSC leaders were the main supporters for school development. They were confident and powerful in the community. Because they were local authorities and former school directors, SSC leaders of the four schools gained high respect from the community and teachers. They were reported to have commitment in supporting the schools as well.

The findings of the current study were consistent with Sanders in terms of the factors that enhanced community participation in education. Sanders (2010) found that leadership roles of the school leaders were important for making partnerships between school, family and community. This contention indicates that to ensure the six types of Epstein's participation take place, school leaders and staff could play roles in facilitation, coordination, designing, implementing, monitoring and evaluating the community participation in education.

Likewise, this research found that the leading roles of the schools and SSCs were crucial to enabling community participation in education. School directors and SSC leaders were found playing roles as communicators and community mobilizers in the schools and in the community. However, the school directors and SSC leaders needed strong management and leadership skills so that they could mobilize community participation (Pellini, 1999). Better leadership and management skills could enable the school and SSCs to more effectively mobilize community members and civil society to participate in education, such as providing training in parenting skills to parents and teachers. 


\subsection{Conclusion}

To conclude, community people and parents in the four schools of Samlot district were involved in education in different ways and at different levels. The participation was categorized into six main types: parenting, learning at home, communicating, volunteering, decision-making and collaborating. The most common form of participation was resource contribution (a form of collaborating ${ }^{6}$ ). This common practice reflects the older traditions of participation.

The participation of education stakeholders occurred unevenly. Parents were commonly involved in children's learning at home but participated less in schools. Local authorities and SSCs frequently got involved directly in school activities. Their involvement was found to involve power relations and negotiation. There was a significant discrepancy between each type of participation with regard to the levels of participation. The participation of parents and community members tended to be passive and indirect. They participated through assisting children learning and via resource contribution. The latter influenced local people's understandings about community participation.

The schools and SSCs were the two partners that brought community people together to participate in improving education. Community people could participate more actively when these two partners have a strong capacity. Teachers and SSCs played various roles in bring community to participate and contribute to the schools and education development. They were facilitators, communicators, coordinators, mobilizers and network connectors. Community and parents tended to have strong levels of trust when the two worked together. 


\section{CHAPTER 7}

\section{CONCLUSION AND RECOMMENDATION}

\subsection{Introduction}

The main purpose of this study was to investigate the practices of community participation in education in the remote district of Cambodia. This purpose was split into four specific objectives: to explore types of community participation in education; to determine the processes of community participation in education; to investigate the methods of community mobilization, focusing on resource mobilization; and to evaluate the degrees of the participation of the community in education. The expected outcomes of the study were to contribute to the small body of literature on community participation in the remote areas in Cambodia and to explore the value of community participation in education for enhancing children's learning. It is hoped that the results of the study may inform policy makers, education personnel, NGOs and MoEYS's departments about the nature of community participation in education in the remote areas, and draw their attention to the participation of the local people in education. It may also draw attention to the most appropriate forms of participation in that context.

To respond to the research objectives, four remote primary schools were chosen as a case study, and mixed research methods were employed for data collection. An interpretive epistemology stance was adopted to report and interpret the perspectives and understanding of the communities. This chapter will highlight key findings, implications and the limitations of the research.

\subsection{Key Findings - Practices of Community Participation in Education}

According to the findings of the study, various groups of education stakeholders were identified in Samlot district, ranging from parents, local authorities, religious institutions, business people, NGOs, micro-finance institutions and children. These education stakeholders participated in education/schools in different ways. They participated through some activities such as volunteering, communicating, parenting, children learning at home, 
collaborating and decision-making. However, the participation among these stakeholders was diverse and uneven.

In the study context, parents appeared to have more direct involvement with children at home than through participation in schools. Parents got involved in children's learning through sending children to school, assisting children's daily schooling, teaching children, providing encouragement to children and checking children's study records and notebooks. They seemed to have less participation in the education program, except for participation in informal consultations, occasional meetings and personal communication with teachers. Parents were likely to have more involvement in their children's learning if they were aware of parenting skills which are relevant to supporting children's learning, and basic teaching methods to help their children. Thus, one recommendation from this study is that schools could provide parenting support and consultations on children's learning to assist parents.

It was clear that the schools tried to diversify their means of communication. The use of formal written communication tools appeared to be ineffective to communicate children's learning progress due to the limits of parental literacy. In the study context, community outreach, teacher-parents meetings and phone calls were more effective options to communicate children's learning progress. These options could be effective tools to support parents and community people in participating productively in education and children's learning.

One interesting finding was the way in which community people collaborate to promote education and children's learning. Students Councils (SCs), School Support Committee (SSCs), local authorities, NGOs, Buddhist monks as well as Youth Clubs participated in school development. They collected children in the community to go to schools and promoted education through sharing education information in the community. They were motivated by the collective purpose of promoting education for the next generation. However, the mobilization of these stakeholders to participate in education focused too much attention on physical infrastructure development which expended significant community resources. It is suggested here that this practice could change to a focus on the 
quality of children's learning rather than physical infrastructure development. The schools and SSCs could be the drivers of this change in this regard.

Another key finding is that SSCs and the schools worked closely together with the school for education development. The schools always had discussions with SSCs about the challenges and school development plan. SSCs represented community people in the schools. The committee participated in most stages in education and school development such as building school development plan, budget management and local resource mobilization. Parents and community people were found to contribute their local resources for school development through SSCs. School directors, teachers and parents paid a lot of respect to their SSC in the decision-making process. SSCs and school administrators had leading roles in making community participation in education.

\subsection{Community Resource Mobilization}

The four selected schools had different ways of mobilizing community resources for school development. Both methods identified were suitable in the local context, and could be applicable in other areas throughout the country or in different countries. The first method was school-led resource mobilization which was carried out by the schools with consultation and advisory support from SSCs. This method was associated with teachers' roles to conduct fundraising in the community. SSCs only provided advice to the schools. Teachers were the facilitators, fundraisers, organizers and communicators.

The second method, delegated-resource mobilization was the responsibility of SSCs to solicit money in the community. This method shows the power distribution among schools and SSCs. As SSC members were local authorities and elderly people who were socially respected, they could use their influence in mobilizing community resources. SSCs were the resource mobilizers and facilitators. The schools that had village leaders as SSC leaders used this method. The method tended to be effective for mobilizing resources, and reflects the genuine participation of community people in SSCs as partners with the schools.

\subsection{Degrees of Community Participation in Education}

Participation in education varied from pseudo-participation to genuine participation, depending on different types of participation and who the participants were. Parental 
involvement in children's learning ( $\_$parenting' and _learning at home') was considered to take place at the level of consultation'. Parents seemed to have little power in decisionmaking. Parents and communities could gain power when they participated in education through volunteering and supporting the schools and communicating their issues. These two forms of participation appeared to support the delivery of services. Participants talked about having a certain level of power in contributing to education. On the other hand, parents' participation through SSCs (through collaborating and decision-making) was at the level of delegated power', as the SSCs who were community representatives had strong power to make decisions regarding education development.

Thus, the degrees of participation were inconsistent. They varied depending on participants and forms through which stakeholders participated.

\subsection{Recommendation for Better Participation in Education}

\subsubsection{Parental Involvement in Children's Learning}

The parental involvement could be more active if the school had parent supporting programs to help parents and community. As suggested by Epstein (2006) and Griffin and Steen (2010), schools could coordinate parenting programs for parents and community people such as forming mothers' groups and providing parenting training to parents so that parents could help with teaching their children at home.

The schools and SSCs could also adopt a model of parental networking within the community which is inclusive of educated and uneducated parents and retired officials. This could be beneficial as educated parents can share their child rearing and parenting skills to the low educated parents. This model appeared to work well in Hong Kong (Pang 1997) where parents pay strong attention to children's learning. This model may be effective and applicable in the Cambodian rural context. This model would need a strong commitment from the schools, SSCs, local authorities and parents with support from MoEYS. The ministry can promote parenting skills to teachers and SSCs.

MoEYS could consider including parenting skills in the pedagogy of schools so that the skills are promoted among new educators. In addition, at the school level, MoEYS could 
promote the culture of sharing best practice with regards to childrearing and children's learning support to parents. A reward system could be given to model parents whose children have a good performance in the schools and in the community. Parents could be a role model for other parents. The schools could conduct regular meetings with parents to share the learning progress of the children and invite model parents to share with other parents. Teachers can promote the culture of parental involvement in children's learning through designing parent-children homework which requires children and parents work together (Epstein \& Van Voorhis, 2001). This technique could gradually change the behaviour of parents towards their children's learning.

\subsubsection{The Focus on Children's Learning}

Community participation was understood as the resource contribution for school development. The practice reflects this understanding by which communities have predominantly prioritized their resource contribution which meant that a lot of money was spent on physical infrastructure construction. A change could be made to focusing on children's learning, thereby making community participation more effective for learning outcomes. This change should start with the schools and SSCs.

This practice should be changed through changing the perception of teachers and the community through changing their practices. The schools could consider the capacity of the school and community when proposing school development projects. To optimize the community resources, the schools could run development projects that are contextually beneficial for children's learning. The school administrators should shift their focus to the participation on children's learning. In this stage, the participation could focus on the quality of children's learning despite the attention on collecting children to schools still

needing to be made. The attention could be made on increasing numeracy and literacy skills by adapting the parent networking system as mentioned above. 


\subsection{Limitations of the Study and Recommendations for Further}

\section{Research}

There were some limitations in this study due to the time limitations in conducting Masters research. The study did not, for example, obtain detailed information from the community members and families in the study area. The scope of investigation on parenting and learning at home, which are types of participation, was limited even though the questionnaire survey was conducted. The study did not explore traditional parenting practices in the remote community, and the impact of traditional practices of parenting on children's learning. This requires further research. The study focused only on the general forms and processes of participation of the community and parents in education.

The method of community mobilization was limited to mobilizing community resources for school development, rather than mobilizing community people to get involved and invest in education. The study investigated how the schools and SSCs worked together to collect community resources to complement government budget for school development. This tended to be material-based and respond to the need to supply learning facilities for education. Further research should focus on methods of mobilizing local people to be more involved in children's learning processes.

\subsection{Research Implication}

Participatory development approaches have been widely used in the education sector in Cambodia. The government, through the MoEYS, shows commitment to include such approaches to improve education. This is shown in the constitution, education law and CFS policies. However, this does not necessarily indicate a real partnership between the schools and communities, because this study showed that power was limited by the enforcement of policy at the upper levels. The government tends to have a one-size fits all guideline and this hampered the role and power of the SSCs in their respective situations. If the MoEYS studied the challenges in policy implementation, it may find places for greater flexibility to accommodate participation in education. 
Even though the study found that the participation of the community in education is beneficial for education development, and the six types of participation were important, it was also found that greater technical support was needed for the schools. On top of that, the schools may benefit from further encouragement from the MoEYs to carry on with community mobilization. The MoEYS does provide policy support, as shown in the Child Friendly School Policy (2007), however further technical and management support could be given through encouragement, incentives and advice to the schools and SSC leaders who perform well in mobilizing community participation for education improvement.

\subsection{Conclusion}

This study discovered a range of social practices in community participation in education, in the four remote schools in Samlot district, Battambang province, Cambodia. The study found that the participation behaviours of the local people in education were influenced by traditional practices. People participated in education largely through resource contribution for their school's physical development. As resource contribution was thought to be important for education, the schools and community leaders as well as education stakeholders tended to prioritize mobilizing the community to contribute their own resources in school development. This behaviour had been passed on from generation to generation. Not only in Cambodia, but also in many other developing countries. This local practice informs the broad body of literature not only in education sector, but also in multisector development that local, remote people appeared to participate in development in different ways. They also have different definitions of participation.

In spite of this, there was a sign of behavioral changes towards improving education. Even though the study did not explore specifically the involvement of parents in their children $\underline{\underline{S}}$ learning at home, there were some indications of the increase in attention of parents and the community in children's learning. This focus less on the bricks and mortar of buildings and more on how parents can support their children at home is a welcome change. Parents were likely to have more involvement in their children's learning if they were aware of how to provide support. This study informs the government and education stakeholders that parents need their assistance to know how to provide quality support to their children. Due to a low level of literacy and a disrupted education system from past historical times, 
parents today need support to know how to assist their children in their studies. This training and information may include knowledge about the curriculum, ideas for helping improve literacy and numeracy at home and knowledge about children's developmental stages.

This thesis has also provided useful information to non-governmental organizations and donors that are focusing on education to pay extra attention on parenting-for-education for parents. Without the skills to support their children in education, parents who are often struggling financially may find it difficult to participate when the most common form is through resource contribution. This thesis has highlighted that this traditional perception may need challenging and support for parents should be a priority for the government, NGOs and others in the education sector. 


\section{LIST OF REFERENCES}

Alabaster, W. (2014). Exclusion in education: Will children in Cambodia be able to complete a full course of primary education by 2015? Knowledge Cultures, 2(5), 16-16.

Arnstein, S. R. (1969). A ladder of citizen participation. Journal of the American Institute of Planners, 35(4), 216-224. doi: 10.1080/01944366908977225

Ayres, D. M. (2000). Tradition, modernity, and the development of education in Cambodia. Comparative Education Review, 44(4), 440-463.

Badloe, C., Flanagan, J., Gore, R., Hozumi, T., Imhof, K., \& So, P. (2007). Universal primary education: Reaching the unreached in Cambodia: New York: UNICEF.

Barbour, R. (2008). Doing focus groups. Trowbridge, Wiltshire: The Cromwell Press Ltd.

Barker, J., \& Smith, F. (2001). Power, positionality and practicality: Carrying out fieldwork with children. Ethics, Place \& Environment, 4(2), 142-147.

Becker, J., \& Niehaves, B. (2007). Epistemological perspectives on IS research: A framework for analysing and systematizing epistemological assumptions. Information Systems Journal, 17(2), 197-214.

Bornstein, M. H. (2005). Handbook of parenting: Volume 4 social conditions and applied parenting. London: Lawrence Erlbaum Associates.

Bray, M. (1999). The private costs of public schooling: Household and community financing: Paris: International Institute for Educational Planning/UNESCO.

Bray, M. (2001). Community partnerships in education: Dimensions, variations and implications. Paris: UNESCO

Bray, M. (2003). Community Initiatives in Education: Goals, dimensions and linkages with governments. Compare: A Journal of Comparative and International Education, 33(1), 31-45. doi:10.1080/03057920302598

Bredenberg,K.(2002).Cluster School Development in Cambodia: Analysis of Process and Outcomes. Phnom Penh: SIDA.

Brehm, W. C., \& Silova, I. (2014). Hidden privatization of public education in Cambodia: Equity implications of private tutoring. Journal for Educational Research Online, $6(1), 94-116$. 
Bryan, J., \& Henry, L. (2012). A model for building school-family-community partnerships: Principles and process. Journal of Counseling \& Development, 90(4), 408-420.

Chambers, R. (1994). The origins and practice of participatory rural appraisal. World Development, 22(7), 953-969. doi: 10.1016/0305-750X(94)90141-4

Chandler, D. P. (2015, 04/07/2015). Encylopedia Britannica. Retrieved 01/10/2015, 2015, from http://www.britannica.com/place/Cambodia

Clayton, T. (1995). French Colonial Education. Education Policy Analysis Archives, 23, 19.

Clayton, T. (2005). Re-orientations in moral education in Cambodia since 1975. Journal of Moral Education, 34(4), 505-517.

Collins, J. M. (2008). Reconstructing access in the Cambodian education system. Inequality in Education (pp. 190-214). Netherlands: Springer.

Cornwall, A. (2006). Historical perspectives on participation in development. Commonwealth \& Comparative Politics, 44(1), 62-83.

Cornwall, A. (2008). Unpacking 'participation': Models, meanings and practices. Community Development Journal, 43(3), 269-283.

Cowen, M., \& Shenton, R. (1995). The invention of development. Power of development, 27-43.

Creswell, J. W. (2013). Research design: Qualitative, quantitative, and mixed methods approaches: SAGE Publications. Thousand Oaks.

Crocker, D. A. (2007). Deliberative participation in local development. Journal of Human Development, 8(3), 431-455.

DeFilippis, J., \& Susan, S. (2008). Communities develop: The question is how? In J. DeFilippis \& S. Saegert (Eds.), The Community Development Reader (pp. 1). New York: Routledge.

Della Porta, D., \& Keating, M. (Eds.). (2008). How many approaches in social sciences? An epistemological introduction. Cambridge: University Press.

Denscombe, M. (2010). The good research guide: For small-scale social research projects. Maidenhead, England: McGraw-Hill/Open University Press.

DeRienzo, H. (2008). Community Organization for Power and Democracy. In J. DeFilippis \& S. Saegert (Eds.), Community Development Reader (First ed., pp. 182-225). New York. Routledge. 
Desai, V., Potter, R. B., \& Ebooks, C. (2014). The companion to development studies (Third edition.). Abingdon, Oxon: Routledge.

DoE. (2015). District Education Statistic 2014-2015. In Samlot final (Ed.). Samlot, Battambang, Cambodia: District office of Education.

Dy, S. S. (2004). Strategies and Policies for Basic Education in Cambodia: Historical Perspectives. International education journal, 5(1), 90-97.

Dykstra, A. H., \& Kucita, P. (1997). School-based management through cluster schools: A case study from Cambodia. UNICEF, Education for All: Making it Work.

Epstein, J. (1992). School and family partnerships. In M. Alkin (Ed.), Encyclopedia of educational research (6th ed., pp. 1139-1151). New York: Macmillan.

Epstein, J. L. (1995). School/family/community partnerships. Phi Delta Kappan, 76(9), 701-712.

Epstein, J. L. (2006). Families, schools, and community partnerships. YC Young Children, 61(1), 40-40. Retrieved from http://search.proquest.com/docview/197603268?accountid=14782

Epstein, J. L., \& Salinas, K. C. (2004). Partnering with families and communities. Educational Leadership, 61(8), 12-19.

Epstein, J. L., \& Van Voorhis, F. L. (2001). More than minutes: Teachers_roles in designing homework. Educational psychologist, 36(3), 181-193.

Epstein, J. L., Sanders, M. G., Simon, B. S., Salinas, K. C., Jansorn, N. R., \& Van Voorhis, F. L. (2002). School, family, and community partnerships: Your handbook for action: Corwin Press. Califonia.

Fragale, A. R., Kim, P. H., \& Pinkley, R. L. (2005). Power dynamics in negotiation. Academy of Management Review, 30(4), 799-822.

Freeman, T. (2006). Best practice' in focus group research: Making sense of different views. Journal of Advanced Nursing, 56(5), 491-497.

French, J. R., \& Raven, B. (2001). The bases of social power. Modern classics of leadership, 2, 309-326.

Garcia, J. A. (2011). Latino politics in America: Community, culture, and interests. Toronto. Rowman \& Littlefield. 
Griffin, D., \& Steen, S. (2010). School-family-community partnerships: Applying Epstein's theory of the six types of involvement to school counselor practice. Professional School Counseling, 13(4), 218-226.

Hillery, G. A. (1955). Definitions of community: Areas of agreement. Rural Sociology, 20, 111-123.

Hopkins, P. (2007). Positionalities and knowledge: Negotiating ethics in practice. ACME: An International E-Journal for Critical Geographies, 6(3), 386-394. https://drive.google.com/file/d/0B1ekqZE5ZIUJVnhuQ311ZTNRWDg/view

Johnson-Bailey, J., Lee, M. Y., Kee, Y., Merriam, S. B., Ntseane, G., \& Muhamad, M. (2001). Power and positionality: Negotiating insider/outsider status within and across cultures. International Journal of Lifelong Education, 20(5), 405-416.

Karnieli-Miller, O., Strier, R., \& Pessach, L. (2009). Power relations in qualitative research. Qualitative Health Research, 19(2), 279-289.

Katyal, K. R., \& Evers, C. W. (2007). Parents-partners or clients? A reconceptualization of home-school interactions. Teaching Education, 18(1), 61-76.

Kayrooz, C., \& Trevitt, C. (2004). Research in organisations and communities: Tales from the real world. London: Allen \& Unwin.

Khong, L. Y.-L., \& Ng, P. T. (2005). School-parent partnerships in Singapore. Educational Research for Policy and Practice, 4(1), 1-11.

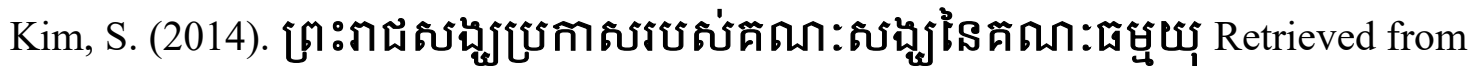
http://www.mocar.gov.kh/

Kitchin, R, \& Tate, N.J. (2000). Conducting research in human geography: Theory, methodology \& practice. Harlow: Pearson Education Limited.

Klein, H., \& Ballantine, J. H. (1999). For parents particularly: Getting involved in our children's education. Childhood Education, 75(3), 170-171.

Kumar, S. (2002). Methods for community participation: A complete guide for practitioners. Methods for community participation: A complete guide for practitioners.

Marockie, H., \& Jones, H. L. (1987). Reducing dropout rates through home-school communication. Education and Urban Society, 19(2), 200-205.

Marshall, C., \& Rossman, G. B. (2006). Designing qualitative research. London: Thousand Oaks. 
Ministry of Education, New Zealand. (2015). Legislation on school boards of trustees. Retrieved from http://www.education.govt.nz/ministry-of-education/regulatory-impact$\underline{\text { statements/education-amendment-bill/legislation-on-board-of-trustees/ }}$

MoEYS. (2007). Policy on Child Friendly Schools. Phnom Penh, Cambodia: Ministry of Education, Youth and Sport.

MoEYS. (2012). School Support Committee Guidelines. Phnom Penh, Cambodia: Ministry of Education, Youth and Sport.

MoEYS. (2014a). Education Strategic Plan 2014-2018. Phnom Penh, Cambodia: Ministry of Education, Youth and Sport.

MoEYS. (2014b). National Action Plan on Early Childhood Care and Development 20142018. Phnom Penh, Cambodia: Ministry of Education, Youth and Sport.

MoEYS. (2015a). Education Statistic \& Indicators 2014-2015. Retrieved from Phnom Penh, Cambodia:

MoEYS. (2015b). Education Statistics \& Indicators 2014/2015: Battambang Province. Phnom Penh, Cambodia: Ministry of Education, Youth and Sport Retrieved from http://www.moeys.gov.kh/en/battambang/1608.html\#.Vfogv2cVjIU.

MoEYS. (2015c). Vision and Mision of the Ministry of Education, Youth and Sport (MoEYS). Retrieved from http://www.moeys.gov.kh/en/aboutus.html\#.VZZtOPkXWuI

Mohan, G., \& Stokke, K. (2000). Participatory development and empowerment: The dangers of localism. Third World Quarterly, 21(2), 247-268.

MoI. (2010). District/Khan Profile: Samlout Retrieved from http://db.ncdd.gov.kh/cdbonline/home/index.castle. Retrieved 17/09/2015, from The National Committee for Sub-National Democratic Development (NCDD) http://db.ncdd.gov.kh/cdbonline/home/index.castle

MoP. (2014a). Annual Progress Report 2013: Achieving Cambodia's millennium development goals. Phnom Penh, Cambodia: Ministry of Planning.

MoP. (2014b). National Strategic Development Plan 2014-2018. Phnom Penh, Cambodia: Ministry of Planning.

Naron, H. C. (2015). Remarks by H.E. Dr. Hang Chuon Naron Paper presented at the National Literacy Campaign 2015, National Institute of Education. Phnom Penh. 
Nelson, N., \& Wright, S. (1995). Power and participatory development: Theory and practice: New York: Intermediate Technology Publications Ltd (ITP).

Nguon, S. (2012). Parental involvement and students' achievement in Cambodia: Focusing on parental resourcing of public schooling. International Journal of Educational Research, 53, 213-224.

Pak, V. (2012). Understanding rural parent-school-community partnerships in Cambodia: Practices, communications and perceptions. The University of Hong Kong, Pokfulam, Hong Kong.

Pang, I. (2004). School-family-community partnership in Hong Kong - perspectives and challenges. Educational Research for Policy and Practice, 3(2), 109-125. doi:http://dx.doi.org/10.1007/s10671-004-5556-7

Pang, I. W., Shen, S. M., Tsoi, S. Y. S., Yip, P. S. F., \& Yung, K. K. (1994). Home school co-operation research report. Hong Kong: The Government Printer.

Pellini, A. (2005). Decentralisation of education in Cambodia: Searching for spaces of participation between traditions and modernity. Compare: A Journal of Comparative and International Education, 35(2), 205-216.

Pellini, A. (2007). Decentralization and community participation: School clusters in Cambodia in School Decentralization in the Context of Globalizing Governance (pp. 175-194): Springer.

Pellini, A., \& Bredenberg, K. (2015). Basic education clusters in Cambodia: Looking at the future while learning from the past. Development in Practice, 25(3), 419-432.

Pretty, J., Guijt, I., Scoones, I., \& Thompson, J. (1995). A trainer's guide for participatory learning and action London. International Institute for Environment and Development.

RGC. (2007). Education Law. Phnom Penh, Cambodia: Ministry of Education, Youth and Sport.

RGC. (2008). Constitution of the Kingdom of Cambodia. Phnom Penh: Senate of the Kingdom of Cambodia.

RGC. (2014). Identification of Poor Households Programmes Retrieved from http://www.idpoor.gov.kh/en/report. Available from Ministry of Planning IDPoor Information System Retrieved 17/09/2015, from Ministry of Planning http://www.idpoor.gov.kh/en/report 
Rose, P. (2003). Community Participation in School Policy and Practice in Malawi: Balancing local knowledge, national policies and international agency priorities. Compare: A Journal of Comparative and International Education, 33(1), 47-64. doi: $10.1080 / 03057920302597$

Rubin, H. J., \& Rubin, I. S. (2011). Qualitative interviewing: The art of hearing data. Sage.

Sanders, M. G. (2001). The role of community in comprehensive school, family, and community partnership programs. The Elementary School Journal, 19-34.

Save the Children Cambodia. (2015). Program Based Budget Reform and Community

Participation in Primary Education in Cambodia 2015. Retrieved from Phnom Penh, Cambodia:

https://cambodia.savethechildren.net/sites/cambodia.savethechildren.net/files/library 4.CRG\%20publication_2\%20Sept.pdf

Shaeffer, S. (1992). Collaborating for educational change: The role of parents and the community in school improvement. International Journal of Educational Development, 12(4), 277-295. doi: http://dx.doi.org/10.1016/0738-0593(92)90004-6

Shaeffer, S. (1994). Participation for educational change: A synthesis of experience: International Institute for Educational Planning. Paris, UNESCO.

Sheldon, S. B. (2007). Improving student attendance with school, family, and community partnerships. The Journal of Educational Research 100 (5): 267-275.

Stewart, D. W., \& Shamdasani, P. N. (2014). Focus groups: Theory and practice (Vol. 20). SAGE Publications.

Sultana, F. (2007). Reflexivity, positionality and participatory ethics: Negotiating fieldwork dilemmas in international research. ACME: An International E-Journal for Critical Geographies, 6(3), 374-385.

Swanepoel, H., \& De Beer, F. (2006). Community Development: Breaking the cycle of poverty. Lansdowne, South Africa. Juta and Company Ltd.

Swift-Morgan, J. (2006). What Community Participation in Schooling Means: Insights from Southern Ethiopia. Harvard Educational Review, 76(3), 339.

Tashakkori, A., \& Teddlie, C. (2003). Major issues and controveries in the use of mixed methods in the social and behavioral sciences. In Handbook of mixed methods in social \& behavioral research, 3-50. 
UN. (2015). Human Development Report. Retrieved from

http://hdr.undp.org/en/countries/profiles/KHM

UNESCO. (2013a). Toward universal learning: What every child should learn Universal Education (Vol. 1, pp. 1-101). Washington, DC.

UNESCO. (2013b). Education for All: Policy Paper Education for All Global Monitoring Report (Vol. 09, pp. 1-9).

Vandana, D. (1995). Community Participation in Development. In D. Vandana \& P. R. B. (Eds.). The Companion to Development Studies. University of London: Oxford University Press Inc.

Vanderstoep, S. W., \& Johnston, D. D. (2009). Research methods for everyday life: USA: Jossey-Bass

WB. (2015). Life Expectancy at Birth, Total (Years) Retrieved from

http://data.worldbank.org/indicator/SP.DYN.LE00.IN. Retrieved 25/09/2015, from

The World Bank http://data.worldbank.org/indicator/SP.DYN.LE00.IN

Williams, R. (2008). The epistemology of knowledge and the knowledge process cycle:

Beyond the -objectivist" vs -interretivist”. Journal of Knowledge Management, $12(4), 72-85$.

Wolf, J. M., Kane, E., \& Strickland, B. (1997). Planning for community participation in education: Office of Sustainable Development, Bureau for Africa, US Agency for International Development.

Yin, R. K. (2011). Applications of case study research: Design and methods. Los Angeles: SAGE Publication, Inc. 


\section{APPENDICES}

Appendix 1: Guiding Questions for Interviews

\begin{tabular}{|c|c|}
\hline $\begin{array}{l}\text { Objective: To id } \\
\text { mobilization }\end{array}$ & $\begin{array}{l}\text { Guiding Questions } \\
\text { y forms and processes of communication and community resource }\end{array}$ \\
\hline Participants & Questions \\
\hline $\begin{array}{l}\text { Interview with } \\
\text { school } \\
\text { principals and } \\
\text { SSC leaders }\end{array}$ & $\begin{array}{l}\text { Q1. What is the community participation in education? } \\
\text { Q2. How have community participation occurred in the } \\
\text { education/schools? (planning, implementing, monitoring, } \\
\text { evaluation) }\end{array}$ \\
\hline & $\begin{array}{l}\text { Q3. Who participate in schools/education? } \\
\text { Q4. What have you/schools done to get communities participate in } \\
\text { the schools? }\end{array}$ \\
\hline & $\begin{array}{l}\text { Q5. What factors motivate/demotivate them to participate in primary } \\
\text { education? }\end{array}$ \\
\hline & $\begin{array}{l}\text { Q6. What are the challenges in getting community involved in } \\
\text { schooling process? }\end{array}$ \\
\hline & $\begin{array}{l}\text { Q7. How is the relationship among schools, communities and local } \\
\text { authorities in education? }\end{array}$ \\
\hline $\begin{array}{l}\text { Interviews with } \\
\text { teachers }\end{array}$ & $\begin{array}{l}\text { Q1. What is community participation in education? } \\
\text { Q2. How has community participation occurred in your school? } \\
\text { Q3. Who participate in your school? } \\
\text { Q4. How is your relationship with parents and communities? } \\
\text { Q5. How do you communicate with parents and communities? } \\
\text { Q6. Do you have any difficulties with the community participation? }\end{array}$ \\
\hline $\begin{array}{l}\text { Interview with } \\
\text { local } \\
\text { authorities and }\end{array}$ & $\begin{array}{l}\text { Q1. What is community participation in education? } \\
\text { Q2. How do you participate in education? (money, labor, materials, } \\
\text { idea, decision making) }\end{array}$ \\
\hline
\end{tabular}




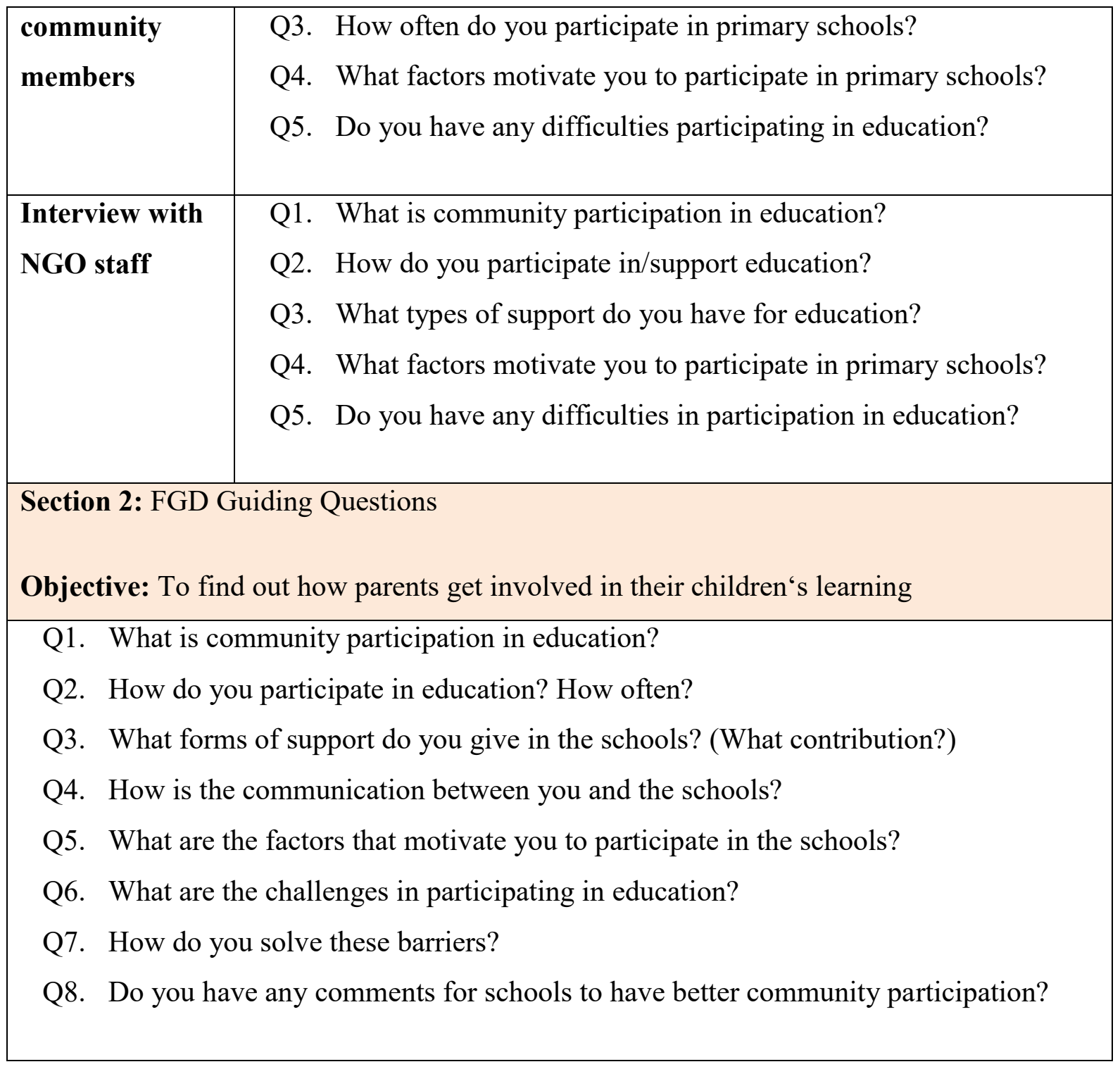


Appendix 2: List of Questionnaire for Survey

Date:

Participant:

Sex: ......

Age:

Level of Education:

Occupation:

Address:

Family members:

\section{Studying in primary school:}

Objective of Questionnaire Survey: To identify forms, motivations and obstacles of community participation in education.

Q1: How important is education? (1= less important, 5= most important)

$\begin{array}{lllll}1 & 2 & 3 & 4 & 5\end{array}$

Q2: How do you participate in education?

Send children to schools

Encourage children to study

Attend the meetings
Disseminate education information

Collect children in the community

Other.

Q3: How do you support your children learning after class?

Teaching children

Encourage children to study
Check children's notebooks

Other

Q4: How often have you been to the schools?

Every day

More than once a week

Whenever invited
Once a week

Once a year

Never

Q5: What are the reasons of going to schools?

Enrollment for children

Meetings with teachers
Bring children to school

Other..... 
Q6: How do you communicate with the schools?

$\square$ Go to school

Attend meetings
Phone call

Other.

Q7: To whom does the school belong?
All of us
Government
Teachers
Other.......

Q8: What do you contribute in education/school development?

Contribute money

Contribute labour
Contribute materials

Looking after school

Other.

Q9: Do you think resource contribution important? (1=less important, 5=most important)

$\begin{array}{lllll}1 & 2 & 3 & 4 & 5\end{array}$

Q10: What are your motivations participating in education?

For children's education

Compassionate in education
For school development

Other

Q11: What are the obstacles of participation in education?

Poor living condition

Busy

No obstacles
Houses are far from schools

Not interested in participating

Other

Q12: Do you have any suggestion for the schools for improvement? 
Appendix 3: Observation Checklist

Date:

Location:

Observation Checklist: For observing school environment and behavior of community toward education.

\section{Physical observation}

\section{School Environment}

Indications of community participation on school playground construction:

Any indication of community participation on school facilities:

\section{In the school office}

Organizational Structure

School Support Committee (SSCs) structure

Student Council (SCs) structure

$\begin{array}{cl}\text { Yes } \square & \text { No } \\ \text { Yes } \square & \text { No } \\ \text { Yes } \square & \text { No }\end{array}$

Other indications of community participation:

\section{Behavior Observation}

\section{Community people in school}

Is there community people present in the school? $\quad \square$ Yes $\quad \square$ No

Comments:

How long do they stay in the school for?

Do they talk to teachers?

Yes

No

\section{Teachers' activities}

Interaction with community people who visit the school:

\section{Students' activities in school:}

Cleaning environment

$\begin{array}{ll}\square \text { Yes } & \square \text { No } \\ \square \text { Yes } & \square \text { No } \\ \square \text { Yes } & \square \text { No } \\ \square \text { Yes } & \square \text { No }\end{array}$

Doing gardening

Help with discipline

Yes

No

Observed activities of students before and after classes: 
Appendix 4: Ethics Approval

TE WHARE WANNANGA O TE OPOKO O TE IKA A MĀUI

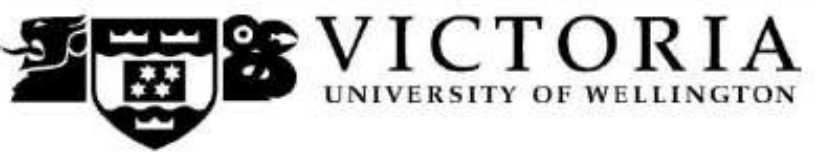

MEMORANDUM

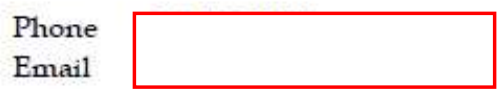

\begin{tabular}{l|l}
\hline TO & \\
\hline COPY TO & \\
\hline FROM & \\
\hline DATE & 5 May 2015 \\
\hline PAGES & 1 \\
\hline & \\
\hline SUBJECT & $\begin{array}{l}\text { Ethics Approval: 21794 } \\
\text { Community Participation in Education in Cambodia }\end{array}$ \\
\hline
\end{tabular}

Thank you for your application for ethical approval, which has now been considered by the Standing Committee of the Human Ethics Committee.

Your application has been approved from the above date and this approval continues until 26 February 2016 . If your data collection is not completed by this date you should apply to the Human Ethics Committee for an extension to this approval.

Best wishes with the research.

Human Ethics Committee 
Appendix 5: Letter from Research Supervisor

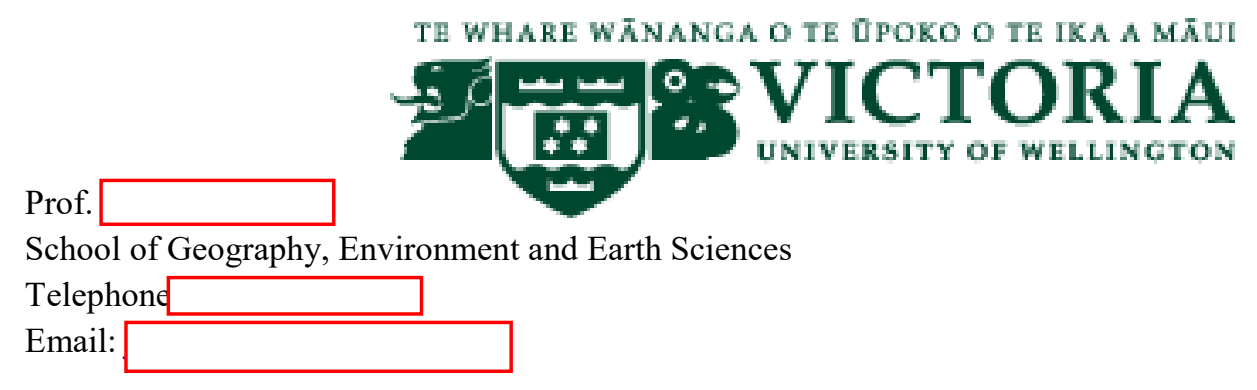

12th April 2015

To Whom It May Concern

\section{Re: Loeurt TO}

This letter is to confirm that Mr. Loeurt TO is fully registered as a Masters student in the Development Studies programme at the School of Geography, Environment and Earth Sciences (SGEES) at Victoria University of Wellington. As a part of this degree, Loeurt is currently undertaking a research project leading to a thesis. The working title of his thesis is: Community Participation in Education in Cambodia”. This research project received approval from the Victoria University Human Ethics Committee on 6th April, 2015 and has also been accepted by the Research Committee of SGEES.

I am one of Loeurt's supervisors and also a Director of the Postgraduate Programme in Development Studies. I fully support Loeurt's proposal and we feel that this research is both important and interesting. It has much potential not only as an academic exercise but also it promises to be able to inform development policy and practice, particularly in the area of education which is crucial for Cambodia and elsewhere.

If you have any further questions or would like to receive further information about the research project, you can contact me as Loeurt's primary supervisor Prof.

$\square$ and $\square$ Loeurt's contact details are: $\square$

We would be most grateful if you could offer any assistance you can to Loeurt and his research.

Yours Sincerely, 
Appendix 6: Information Sheet for Interviews

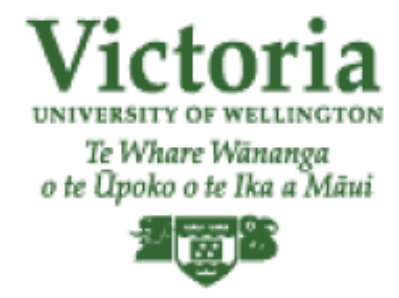

\section{Participant Information Sheet}

$\begin{array}{lll}\text { Study title: } & \text { Community Participation in Education in Cambodia } \\ \text { Locality: } & \begin{array}{l}\text { Samlot District, Battambang } \\ \text { Province, Cambodia }\end{array} & \begin{array}{l}\text { Ethics committee } \\ \text { ref.: }\end{array} \\ & \text { Loeurt TO } & \text { Contact phone } \\ \text { Lead } & \text { number: } \\ \text { investigator: } & & \text { n }\end{array}$

You are invited to take part in a study on Community Participation in Education. Whether or not you take part is your choice. If you don't want to take part, you don't have to give a reason. If you do want to take part now, but change your mind later, you can pull out of the study at any time during data collection period between 1st May and 30th June, 2015.

This Participant Information Sheet will help you decide if you'd like to take part. It sets out why we are doing the study, what your participation would involve, what the benefits and risks to you might be, and what would happen after the study ends. We will go through this information with you and answer any questions you may have.

If you agree to take part in this study, you will be asked to sign the Consent Form on the last page of this document. You will be given a copy of both the Participant Information Sheet and the Consent Form to keep.

- This study is for the fulfilment of my Master Degree in Development Studies.

- This research will enable you to have a chance to express your opinion about participation in education.

- This study is funded by the NZAID scholarship program.

- VUW HEC ethics approval for this study has been granted

- The purpose of this study is to determine the forms and levels of participation of parents, community members, civil society, and local authority in primary school education in Cambodia.

- School principals, teachers, parents, community members, local authority, nongovernmental organization staff, religious leaders, businesspeople and other relevant 
stakeholders in Tasanh and Sung commune, Samlot district are being invited to participate in this study.

- You are one of the participants who is purposively selected to take part in the study.

- Your input is important for this study, and it reflects the situation of the community participation in your area.

- The interview will cover the forms and levels of community participation in primary schools in the two communes in Samlot district.

- This is a one-to-one interview which takes about 40 minutes with some main questions followed by some follow up questions. At the end of the interview, you will be given an opportunity to ask any concerning questions.

- The questionnaires were translated into Khmer language by myself, and the interview will also be transcribed by my own.

- To complement my note, an audio recorder will be used to record this interviews.

- This interview is being conducted in a comfortable place for you as a participant. If you feel insecure or inconvenient, you can tell me to change the location.

- You are free to decline to participate, or to withdraw from the research at any practicable time, without experiencing any disadvantage.

- Any materials you provide and audiotapes will be wiped off without any costs to you if you decline to participate in the study.

- All written materials will be kept in a locked file; access restricted to investigator.

- All electronic information will be password-protected; access restricted to the investigator.

- All questionnaires, interview notes and similar materials will be destroyed at its conclusion

- Research finding will be ultimately printed out and stored in VUW's library for documentation.

If you have any questions, concerns or complaints about the study at any stage, you can contact:

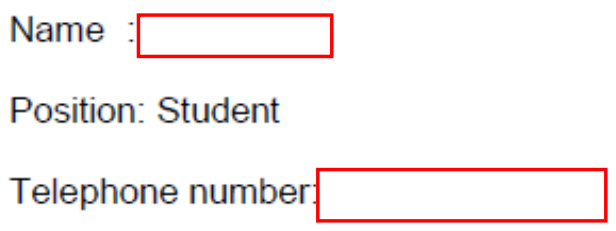

Supervisor:

Telephone

Email:

Email 


\section{Victoria UNIVERSITY OF WELLINGTON \\ Te Whare Wānanga \\ o te Qpoko o fe Ika a Mäui

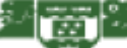

\section{Consent Form}

\section{Please tick to indicate you consent to the following}

I have read, or have had read to me in my first language, and I understand the Participant Information Sheet.

I have been given sufficient time to consider whether or not to participate in this study.

I am satisfied with the answers I have been given regarding the study and I have a copy of this consent form and information sheet.

I understand that taking part in this study is voluntary (my choice) and that I may withdraw from the study at any time during data collection period between 1st May and 30th June, 2015.

If I decide to withdraw from the study, I agree that the information collected about me up to the point when I withdraw may continue to be processed.

I understand that my participation in this study is confidential and that no material, which could identify me personally, will be used in any reports on this study, unless I specify otherwise.

I know who to contact if I have any questions about the study in general.

I wish to receive a summary of the results from the study.

I agree to an audio recording being made of the interview.

Declaration by participant:

I hereby consent to take part in this study.

Participant's name:

\section{Signature:}

\section{Date:}

\section{Declaration by member of research team:}

I have given a verbal explanation of the research project to the participant, and have answered the participant's questions about it.

I believe that the participant understands the study and has given informed consent to participate.

Researcher's name: 
Appendix 8: Information Sheet for FGDs

\title{
Victoria \\ UNTVERSITY OF WELLINCTON \\ Te Whare Wänanga \\ o te Upoko o te $\mathrm{lka}$ a Mãui

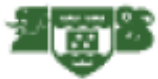

\section{Participant Information Sheet}

\author{
Study title: $\quad$ Community Participation in Education in Cambodia \\ Locality: $\quad$ Samlot District, Battambang $\quad$ Ethics committee \\ Province, Cambodia ref.: \\ Lead Loeurt TO Contact phone \\ investigator: number:
}

You are invited to take part in a study on Community Participation in Education. Whether or not you take part is your choice. If you don't want to take part, you don't have to give a reason. If you do want to take part now, but change your mind later, you can pull out of the study at any time during data collection period between 1st May and 30th June, 2015.

This Participant Information Sheet will help you decide if you'd like to take part. It sets out why we are doing the study, what your participation would involve, what the benefits and risks to you might be, and what would happen after the study ends. We will go through this information with you and answer any questions you may have.

If you agree to take part in this study, you will be asked to sign the Consent Form on the last page of this document. You will be given a copy of both the Participant Information Sheet and the Consent Form to keep.

- This study is for the fulfilment of my Master Degree in Development Studies.

- This research will enable you to have a chance to express your opinion about participation in education.

- This study is funded by the NZAID scholarship program.

- VUW HEC ethics approval for this study has been granted

- The purpose of this study is to determine the forms and levels of participation of parents, community members, civil society, and local authority in primary school education in Cambodia.

- School principals, teachers, parents, community members, local authority, nongovernmental organization staff, religious leaders, businesspeople and other relevant 
stakeholders in Tasanh and Sung commune, Samlot district are being invited to participate in this study.

- You are one of the participants who is randomly selected to take part in the study.

- Your input is important for this study, and it reflects the situation of the community participation in your area.

- The discussion will cover how parents and community members get involved in primary schools in the two communes in Samlot district.

- This is a focus group discussion (FGD) which takes about 60 minutes with some main questions followed by some follow up questions. At the end of the discussion, you will be given an opportunity to ask any concerning questions.

- The questions were translated into Khmer language by myself, and the note from this discussion will also be transcribed by my own.

- To complement my note, an audio recorder will be used to record this discussion.

- This FGD is being conducted in a comfortable place for you as a participant. If you feel insecure or inconvenient, you can tell me to change the location.

- You are free to decline to participate, or to withdraw from the research at any practicable time, without experiencing any disadvantage.

- Any materials you provide and audiotapes will be wiped off without any costs to you if you decline to participate in the study.

- All written materials will be kept in a locked file; access restricted to investigator.

- All electronic information will be password-protected; access restricted to the investigator.

- All questionnaires, notes and similar materials will be destroyed at its conclusion.

- Research finding will be ultimately printed out and stored in VUW's library for documentation.

If you have any questions, concerns or complaints about the study at any stage, you can contact:

Name : Loeurt To

Position: Student

Telephone number:

Email:
Supervisor:

Telephone

Email: 


\section{Victoria \\ UNIVERSITY OF WELLINGTON \\ Te Whare Wānanga \\ o te Qpoko o te lka a Mäui

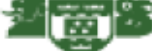

\section{Consent Form}

\section{Please tick to indicate you consent to the following}

I have read, or have had read to me in my first language, and I understand the Participant Information Sheet.

I have been given sufficient time to consider whether or not to participate in this study.

I am satisfied with the answers I have been given regarding the study and I have a copy of this consent form and information sheet.

I understand that taking part in this study is voluntary (my choice) and that I may withdraw from the study at any time during data collection period between 1st May and 30th June, 2015.

If I decide to withdraw from the study, I agree that the information collected about me up to the point when I withdraw may continue to be processed.

I understand that my participation in this study is confidential and that no material, which could identify me personally, will be used in any reports on this study, unless I specify otherwise.

I know who to contact if I have any questions about the study in general.

I agree to keep all matters discussed and identities of the group members confidential.

I wish to receive a summary of the results from the study.

I agree to an audio recording being made of the interview.

Declaration by participant:

I hereby consent to take part in this study.

Participant's name:

\begin{tabular}{ll}
\hline Signature: & Date: \\
\hline Declaration by member of research team: &
\end{tabular}

I have given a verbal explanation of the research project to the participant, and have answered the participant's questions about it.

I believe that the participant understands the study and has given informed consent to participate.

Researcher's name: 
Appendix 10: Permission Letter from DoE to Conduct a Study with Teachers

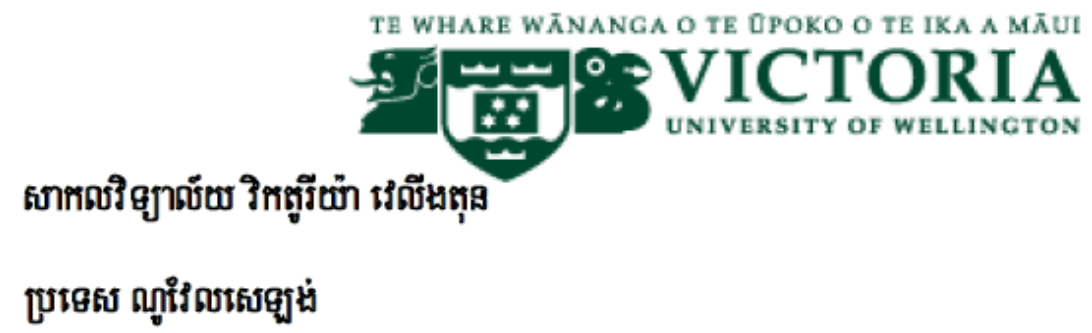

ธูษเผารตนู่ล

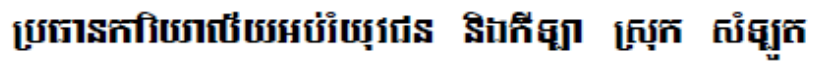

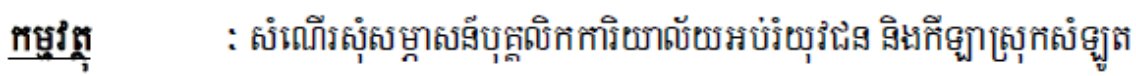

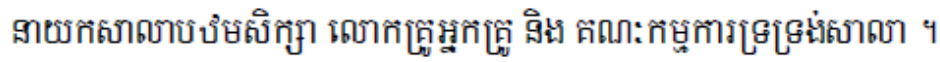

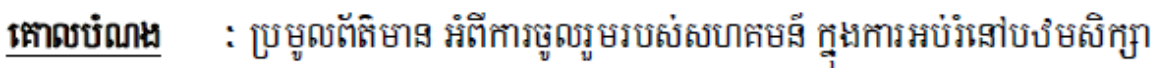

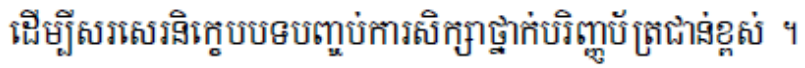

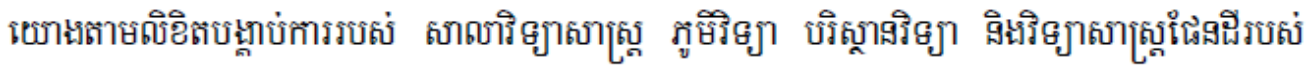

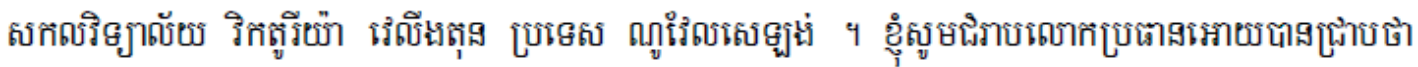

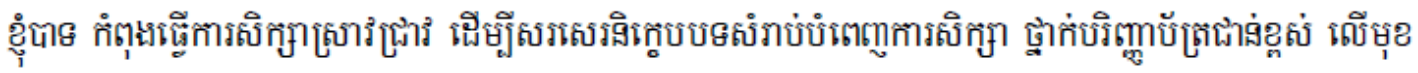

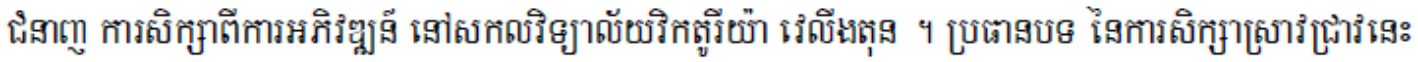

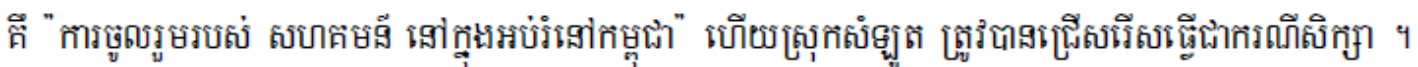

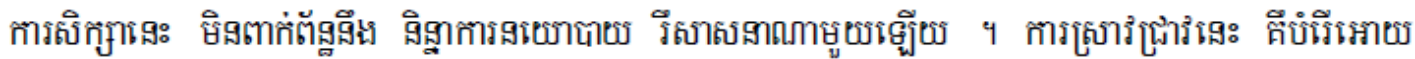

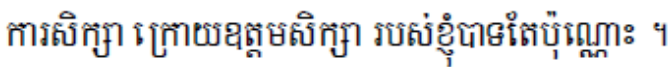

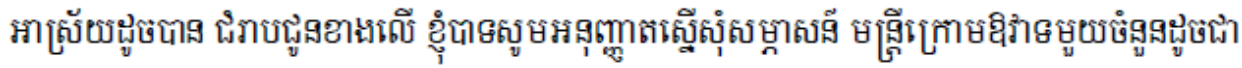

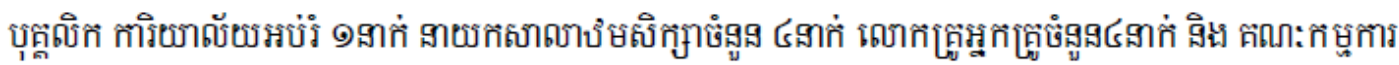

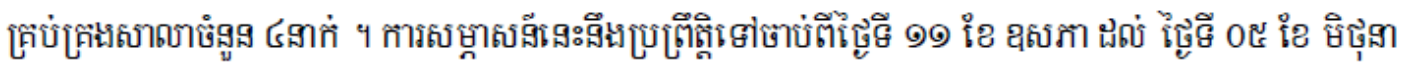

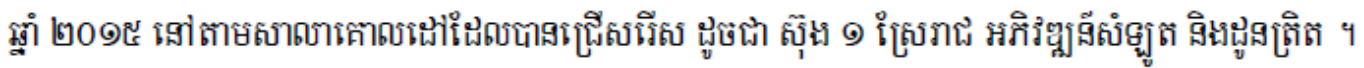

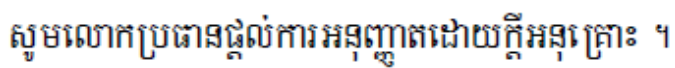

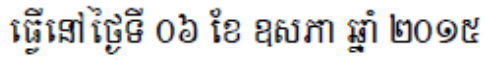

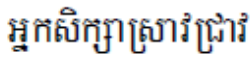




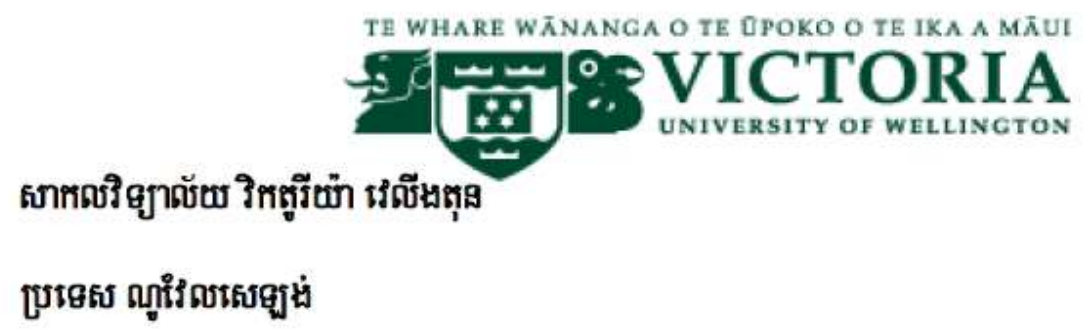

โูยเการตนีด

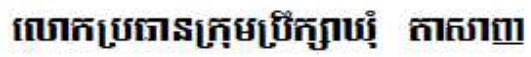

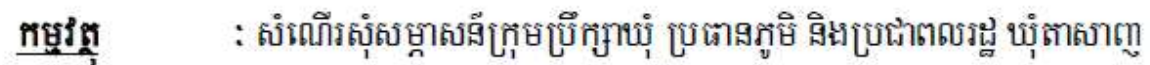

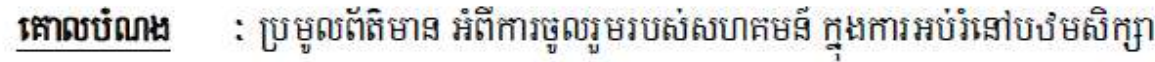

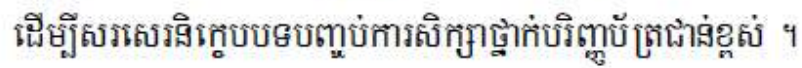

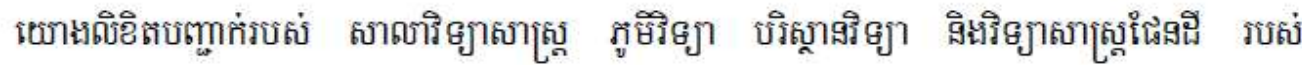

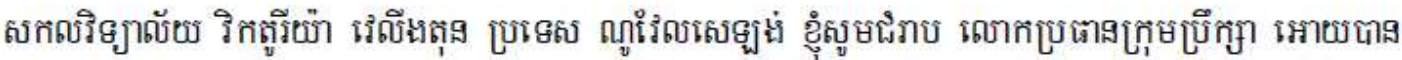

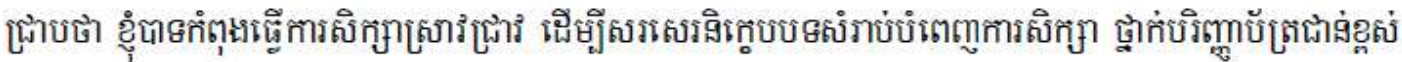

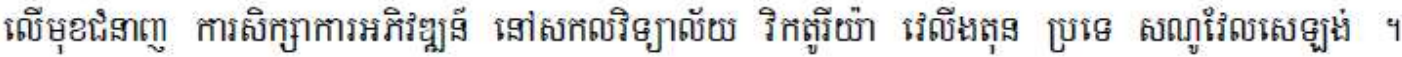

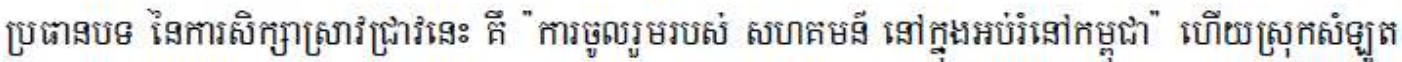

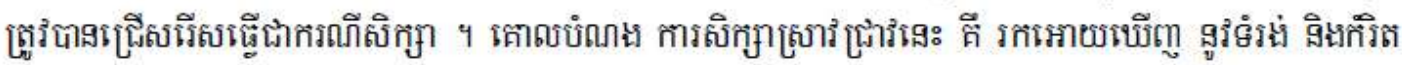

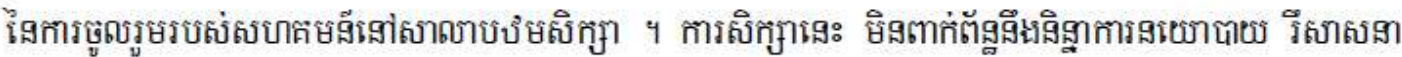

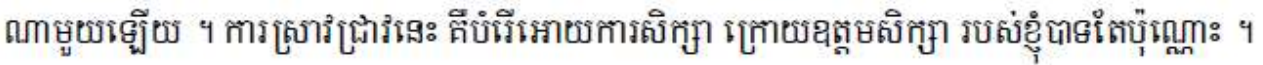

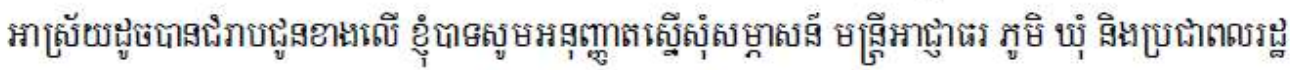

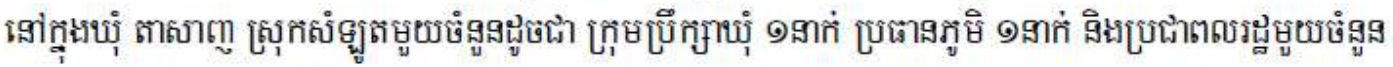

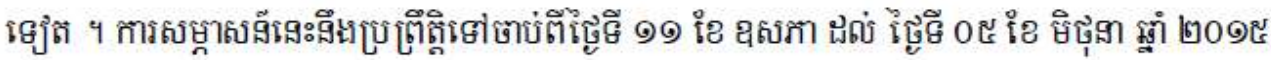

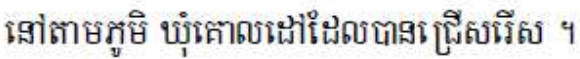

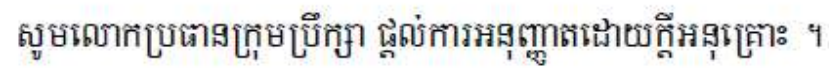

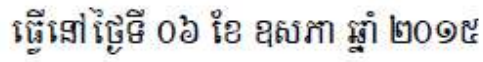

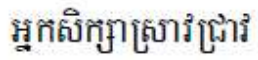


Appendix 12: Permission Letter from Sung Commune

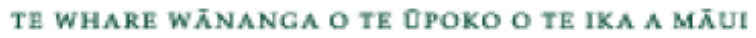 ธากถริตูาถัธช วิกหูรีธี่า นรถีเหุด}

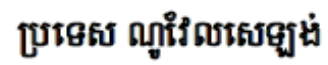

\section{ธูษเคารตึี}

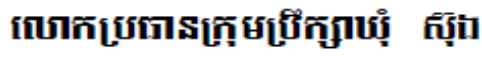

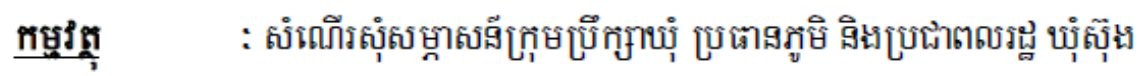

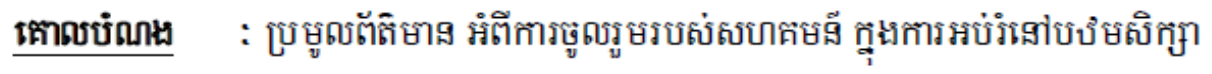

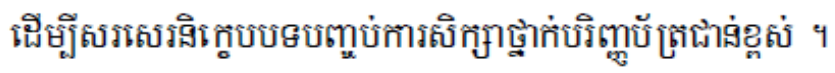

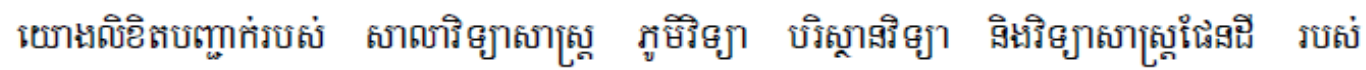

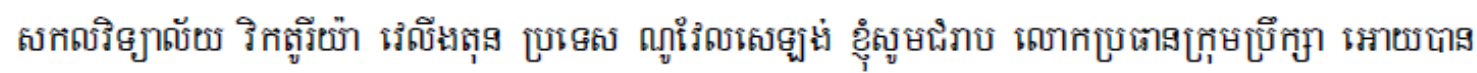

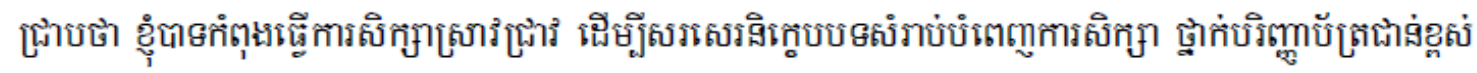

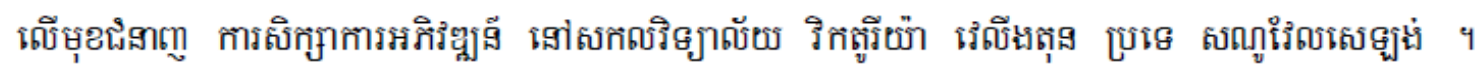

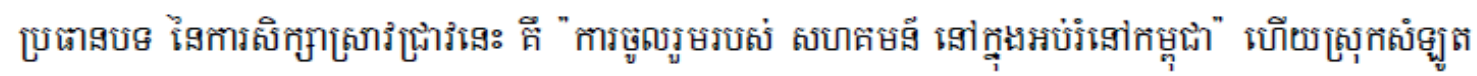

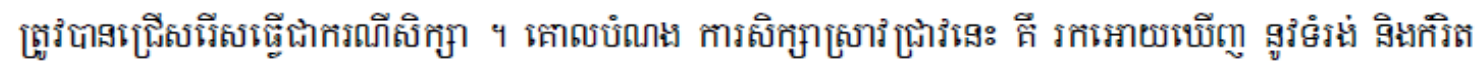

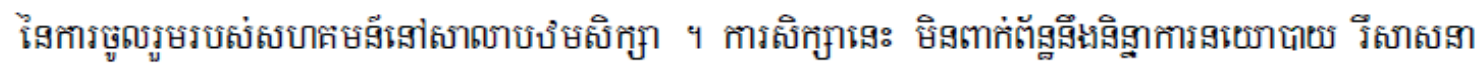

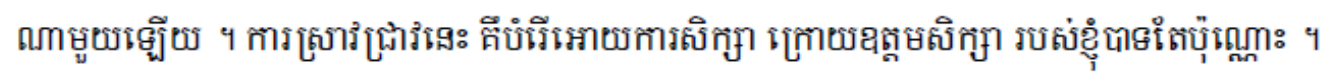

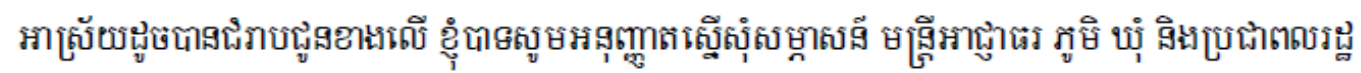

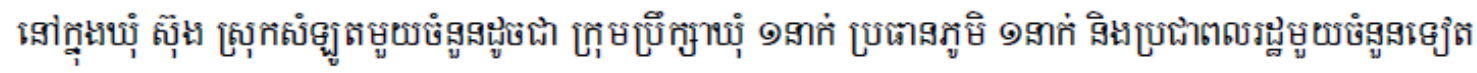

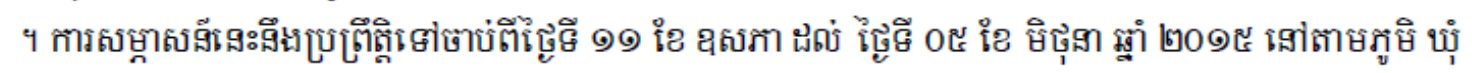

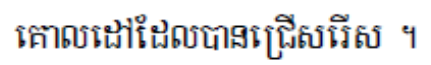

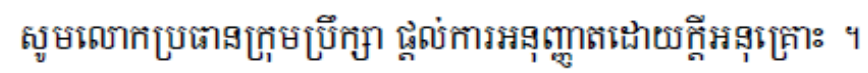

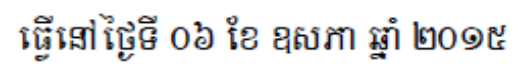

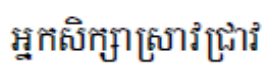


Appendix 13: Fund Raising Letter for School Renovation

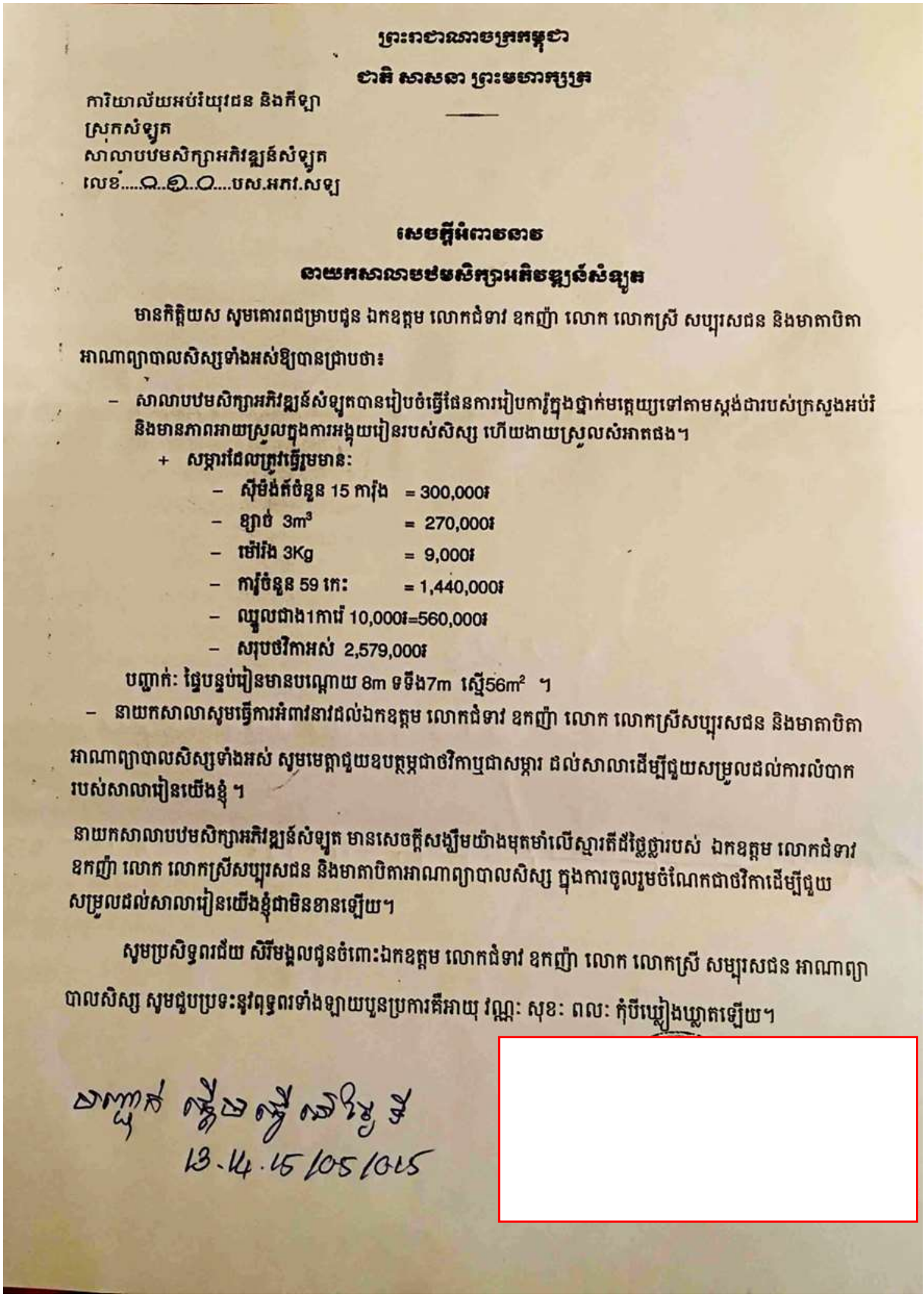


Appendix 14: Invoice of Money Contribution

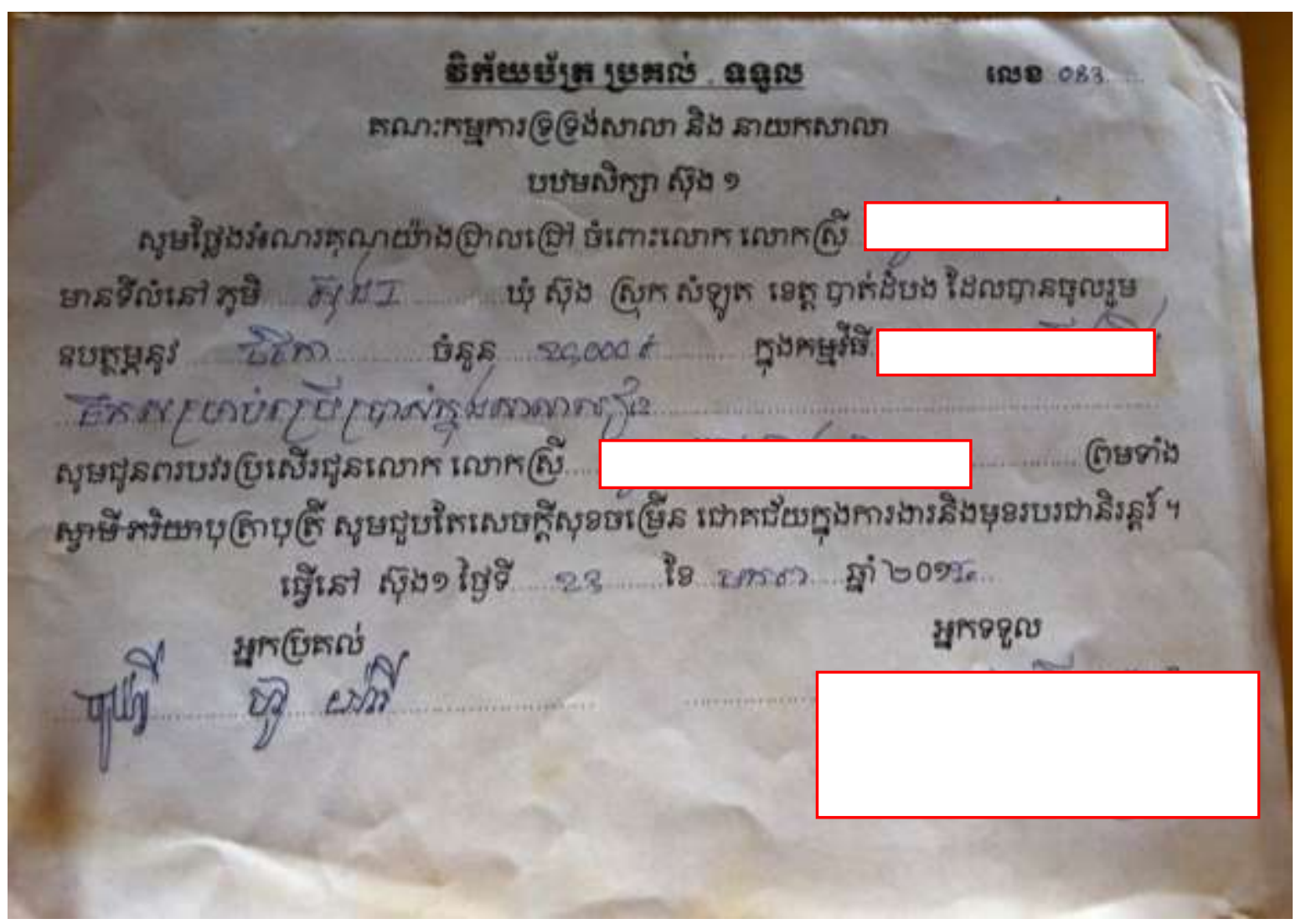

